\title{
ipen
}

INSTITUTO DE PESQUISAS ENERGÉTICAS E NUCLEARES AUTARQUIA ASSOCIADA À UNIVERSIDADE DE SÃO PAULO

\section{SÍNTESE E CARACTERIZAÇÃO DE MANGANITO DE NEODÍMIO DOPADO COM ESTRÔNCIO UTILIZADO COMO CATODO EM CÉLULAS A COMBUSTÍVEL DE ÓXIDO SÓLIDO DE TEMPERATURA INTERMEDIÁRIA}

REINALDO AZEVEDO VARGAS

Dissertação apresentada como parte dos requisitos para obtenção do Grau de Mestre em Ciências na Área de Tecnologia Nuclear - Materiais

Orientadora:

Dra. Emília Satoshi Miyamaru Seo 

INSTITUTO DE PESQUISAS ENERGÉTICAS E NUCLEARES AUTARQUIA ASSOCIADA À UNIVERSIDADE DE SÃO PAULO

\section{SÍNTESE E CARACTERIZAÇÃO DE MANGANITO DE NEODÍMIO DOPADO COM ESTRÔNCIO UTILIZADO COMO CATODO EM CÉLULAS A COMBUSTÍVEL DE ÓXIDO SÓLIDO DE TEMPERATURA INTERMEDIÁRIA}

REINALDO AZEVEDO VARGAS

Dissertação apresentada como parte dos requisitos para obtenção do Grau de Mestre em Ciências na Área de Tecnologia Nuclear - Materiais

Orientadora:

Dra. Emília Satoshi Miyamaru Seo

SÃO PAULO 


\section{DEDICATÓRIA}

Aos meus pais Francisco e Lizete, ao meu irmão Renato, e a Giovanna, pela formação, compreensão, apoio, amor e carinho. 


\section{AGRADECIMENTOS}

Primeiramente ao Instituto de Pesquisas Energéticas e Nucleares (IPEN), ao Centro de Ciência e Tecnologia de Materiais (CCTM) e a Universidade de São Paulo (USP) pela oportunidade de realizar o meu Mestrado.

Ao Conselho Nacional de Desenvolvimento Científico e Tecnológico (CNPq) e a Rede de Pilhas a Combustível de Óxido Sólido (Rede PaCOS) pela concessão da bolsa durante o Mestrado.

A Dra. Emília Satoshi Miyamaru Seo pela orientação, experiência, dedicação, paciência e amizade.

Ao Msc. Rubens Chiba e ao Marco Andreoli pela experiência, aprendizado, apoio, discussão, colaboração e amizade.

A Dra. Sonia R. H. M. Castanho, Dra Dolores R. R. Lazar, Dr. Marcelo Linardi e Dr. Valter Ussui pelas colaborações na infra-estrutura dos laboratórios.

Ao Msc. Antonio Carlos da Silva e Msc. Luiz Fernando Grespan Setz pelo aprendizado, apoio, incentivo e amizade.

Ao Dr. Wagner dos Santos Oliveira pelo aprendizado sobre a tecnologia de células a combustível.

Ao Dr. Egberto Gomes Franco pela experiência, incentivo e amizade.

Ao Dr. Fabio Coral Fonseca, Dra. Eliana Aricó e Daniel Nogueira Rodrigues dos Santos pelo apoio e colaboração nas medidas de caracterizações térmicas e elétricas.

Ao Dr. Hamilton Perez Soares Corrêa (UNESP) pela amizade e colaboração e discussão no entendimento teórico sobre difratogramas de raios $\mathrm{X}$. 
A Dra Sheila Cristina Canobre (USF) pelo apoio, incentivo, colaboração em análises de microscopia eletrônica de varredura e amizade.

Ao Dr. Thomaz Augusto Guisard Restivo pelo entendimento teórico, colaboração na realização das análises de expansão térmica e amizade.

Ao Dr. Valter Ussui pelo entendimento teórico, colaboração nas medidas de área de superfície específica e amizade.

A Dra Vera Lúcia Salvador pelas análises de fluorescência de raios $\mathrm{X}$.

Ao Dr. Jose Roberto Martinelli pelo entendimento teórico e realização das análises de distribuição granulométrica.

Ao Msc. Edson Pereira Soares pela amizade e momentos de ajuda.

Aos pesquisadores e profissionais dos laboratórios de Insumos e Reologia (Chieko, Dolores, Joana, Walter Kenji, Sandra, Valter Ussui e Valdir) pelo aprendizado, auxílio, colaboração e amizade.

A todos meus amigos (sem exceções) e profissionais do CCTM, do Centro de Química e Meio Ambiente (CQMA) e do PROCEL pela amizade, auxílio e contribuição nas análises contidas neste trabalho.

Aos profissionais da CPG (Ana, Cupertino, Daniele, Fernando, Ilze, Magali, Maria e Vera) por todo auxílio e atenção.

Aos funcionários da biblioteca "Terezine Arantes Ferraz" do IPEN e da biblioteca da Escola Politécnica da USP, pela total atenção e eficiência.

Aos integrantes da banca examinadora, Dr. Samuel Marcio Toffoli e Dra. Sonia R. H. M. Castanho, pela avaliação e contribuição nesta dissertação.

A todos que, direta ou indiretamente, colaboraram com este trabalho. 
"Embora nós, seres humanos, sejamos muito limitados fisicamente, nossas mentes estão livres para explorar todo o universo e para avançar audaciosamente para onde até mesmo a ficção teme seguir" (Stephen Hawking). 


\title{
SÍNTESE E CARACTERIZAÇÃO DE \\ MANGANITO DE NEODÍMIO DOPADO COM ESTRÔNCIO \\ UTILIZADO COMO CATODO EM CÉLULAS A COMBUSTÍVEL DE \\ ÓXIDO SÓLIDO DE TEMPERATURA INTERMEDIÁRIA
}

REINALDO AZEVEDO VARGAS

\begin{abstract}
RESUMO
O manganito de neodímio dopado com estrôncio (NSM) é um dos materiais catódicos alternativos e que estão sendo estudados e pesquisados para aplicação em células a combustível de óxido sólido de temperatura intermediária (ITSOFCs). O estrôncio (Sr) auxilia consideravelmente na condutividade elétrica e na proximidade do coeficiente de expansão térmica do NSM com os eletrólitos de céria gadolínia $(G D C)$ e céria samária $(S D C)$, e que tornam o material adequado ao uso em temperaturas entre 500 e $800^{\circ} \mathrm{C}$. Seguindo este contexto, o presente trabalho é uma contribuição ao estudo da síntese de NSM com diferentes concentrações molares de $\operatorname{Sr}(10,30$ e $50 \%)$, através da técnica de reação no estado sólido. Os materiais foram obtidos e caracterizados visando avaliá-los quanto às características adequadas para emprego na ITSOFC. Após a síntese dos pós e processamento do material sinterizado, avaliou-se principalmente o teor do dopante $\mathrm{Sr}$ para a identificação das composições químicas obtidas, estrutura cristalina formada, morfologia dos pós e cerâmicas, além da expansão térmica e condutividade elétrica do material sinterizado. Verificou-se que os valores das concentrações molares dos elementos químicos constituintes para a formação do NSM estão próximos dos valores calculados estequiometricamente antes da etapa de calcinação. A porosidade se mostrou mais adequada para as amostras sinterizadas a 1100 e a $1200^{\circ} \mathrm{C}$. Comprovou-se que, o teor de dopante não altera significativamente a área de superfície específica e o valor das densidades. Os coeficientes de expansão térmica encontrados estão bastante próximos aos eletrólitos comerciais e verificou-se que com o aumento das concentrações molares de estrôncio, ocorre o acréscimo nos valores de coeficientes de expansão térmica. A condutividade elétrica está adequada para aplicação como material catódico. Os resultados mostram que a síntese por mistura de sólidos apesar de ter as suas desvantagens, quando realizada com cuidados, proporciona pós de NSM, com boas características físicas, químicas e microestruturais. Conclui-se que as características do material com composição de $30 \%$ em mol de $\mathrm{Sr}$ é a mais adequada para a preparação de suspensões cerâmicas para posterior deposição no eletrólito sólido de $G D C$ e/ou $S D C$, embora sejam necessários outros estudos das características deste material como dispositivo eletroquímico para aplicação em ITSOFCs.
\end{abstract}




\title{
SYNTHESIS AND CHARACTERIZATION OF \\ STRONTIUM-DOPED NEODYMIUM MANGANITE \\ USED AS CATHODE IN INTERMEDIATE TEMPERATURE \\ SOLID OXIDE FUEL CELLS
}

REINALDO AZEVEDO VARGAS

\begin{abstract}
The strontium-doped neodymium manganite (NSM) is one of the alternative cathodic materials and they have been studied and searched for application in intermediate temperature solid oxide fuel cells (ITSOFCs). The strontium (Sr) assists considerably in the electric conductivity and in the proximity of the thermal expansion of the NSM with electrolytes of ceria doped with gadolinium (GDC) or samarium ( $S D C$ ), allowing them to become the adequate material for the use in temperatures between 500 and $800^{\circ} \mathrm{C}$. Following this context, the present work is a contribution to the study of the synthesis of NSM with different molar concentrations of $\mathrm{Sr}(10,30$ and $50 \%)$, through the technique of solid state reaction. The materials were obtained and characterized to be adjusted to the requested characteristics for operating in the ITSOFC. After the synthesis of the powders and processing the sintered material, it was evaluated the concentration of $\mathrm{Sr}$ for the identification of chemical compositions, crystalline structure, powders morphology and ceramics, besides the thermal expansion and electric conductivity of the sintered material. It was verified that the values of the molar concentrations of the constituent chemical elements of the NSM are close to the values theoretically calculated before the stage of calcination. The porosity showed to be more adequate for the samples sintered at 1100 and $1200{ }^{\circ} \mathrm{C}$. One proved that, the increase of the Sr, relatively little, diminishes the specific surface area and the value of the densities and the coefficients of thermal expansion of the sintered samples. The found coefficients of thermal expansion are sufficiently close to the ones of commercial electrolytes and the electric conductivity is adequate for a cathodic application as material. The results show that the synthesis by solid state reaction, although having its disadvantages, provides powders of NSM with good physical, chemical and microstructural characteristics when carried with certain cares. It is concluded that the composition of $30 \%$ in $\mathrm{mol}$ of $\mathrm{Sr}$ and sintered at $1200{ }^{\circ} \mathrm{C}$ is the best for the preparation of ceramic suspensions for posterior deposition on the solid electrolyte of GDC and/or SDC, even so further studies are necessary to completely adjust this material to be used in a electrochemical device for application in ITSOFCs.
\end{abstract}




\section{SUMÁRIO}

LISTA DE TABELAS

LISTA DE ILUSTRAÇÕES

ii

LISTA DE ABREVIATURAS E SIGLAS .............................................................. iv

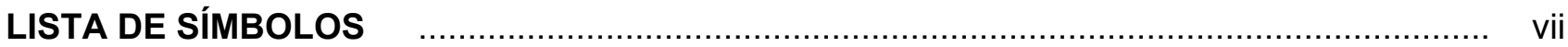

1. INTRODUÇÃO

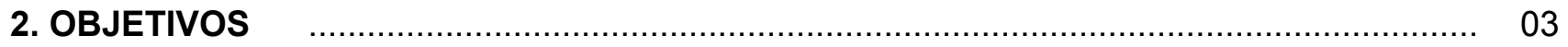

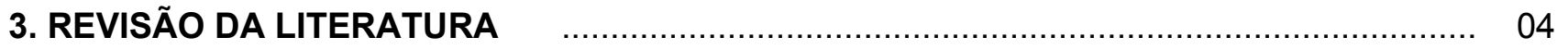

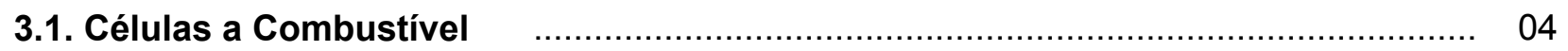

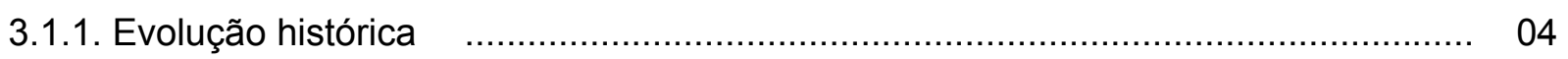

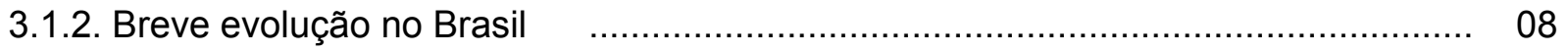

3.1.3. O conceito

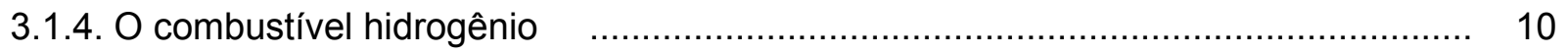

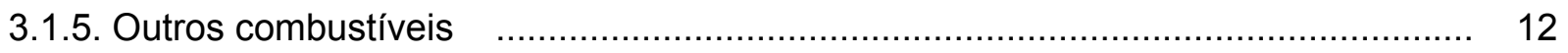

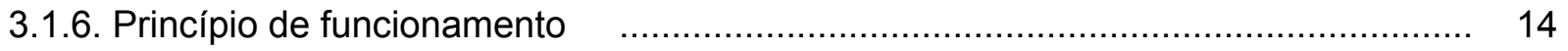

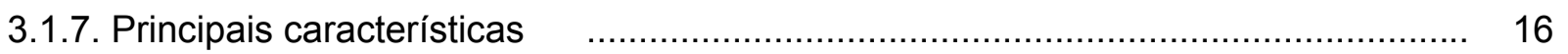

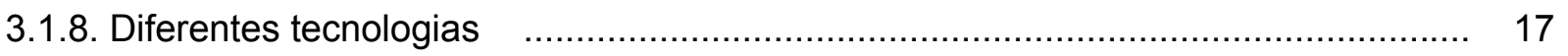

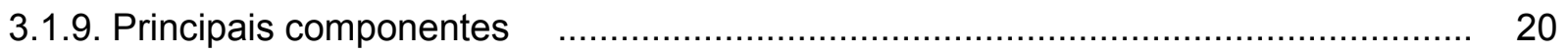

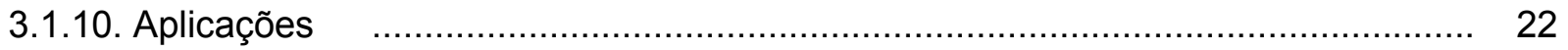

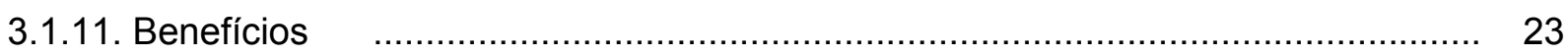

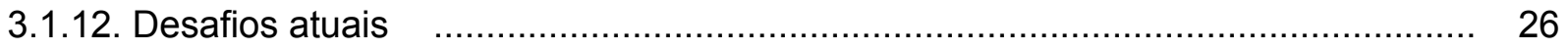

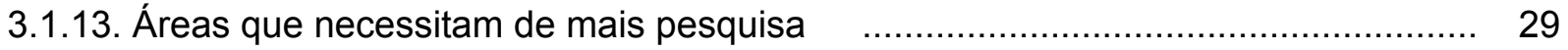

3.1.14. Pesquisa e desenvolvimento no Brasil $\quad$..................................................... 30

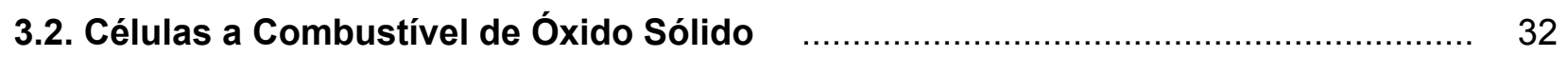

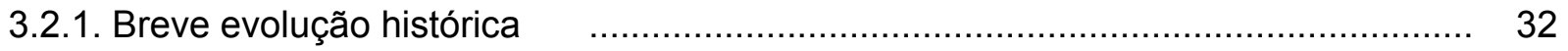

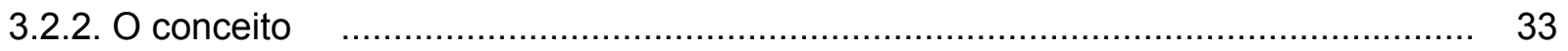

3.2.3. Princípio de funcionamento $\quad$................................................................ 34 


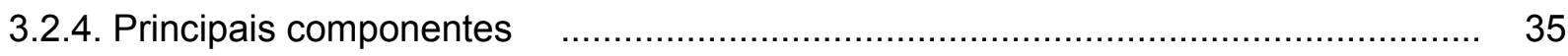

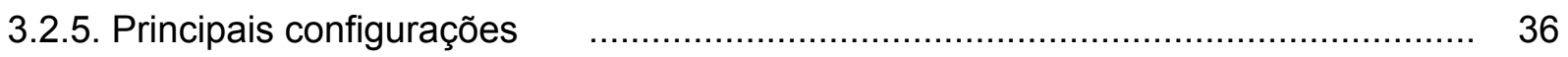

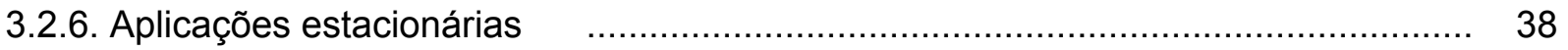

3.2.7. Célula a combustível de óxido sólido de temperatura intermediária $\quad$..................... 39

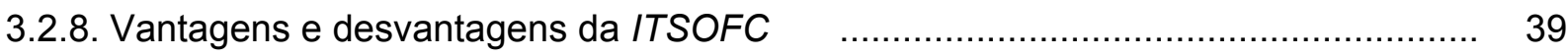

3.2.9. Pesquisa e desenvolvimento no Brasil $\quad$........................................................ 40

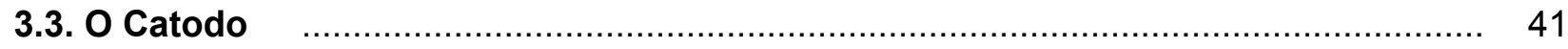

3.4. Manganito de Neodímio Dopado com Estrôncio $\quad$............................................... 43

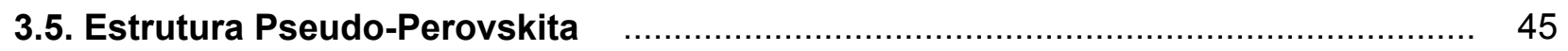

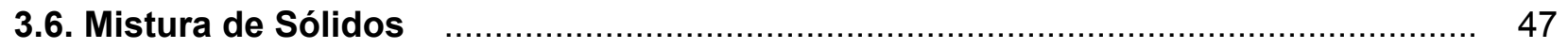

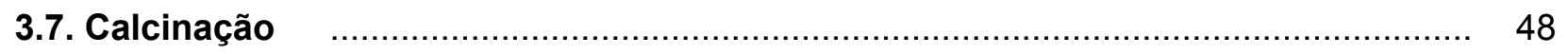

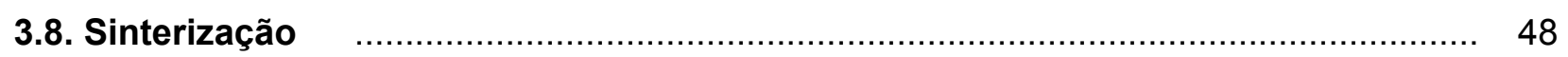

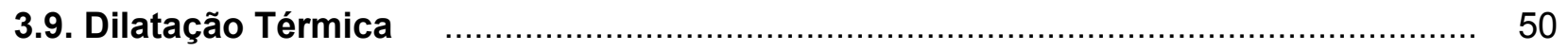

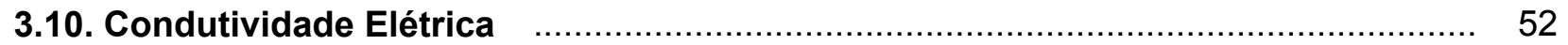

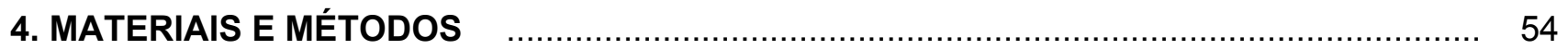

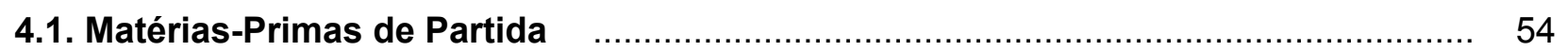

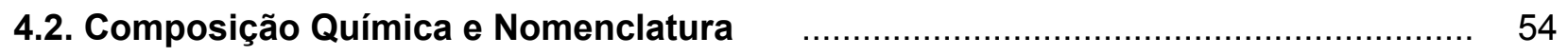

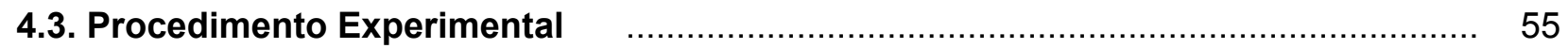

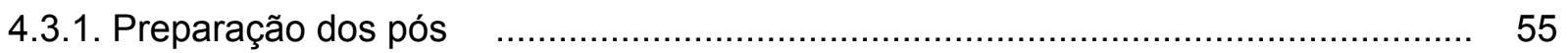

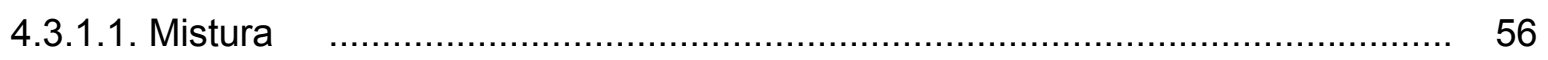

4.3.2. Caracterização dos pós após a etapa de mistura $\quad$......................................... 56

4.3.2.1. Análise térmica gravimétrica e análise térmica diferencial $\quad$......................... 56

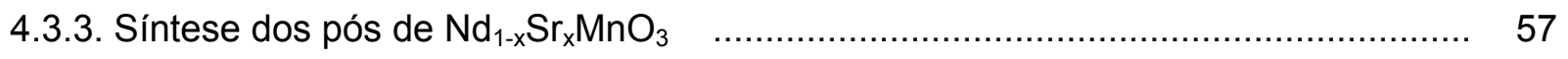

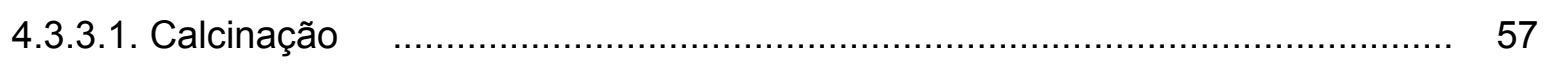

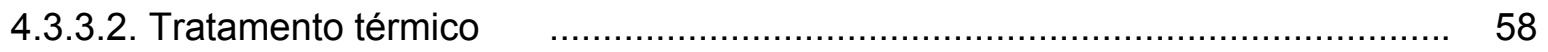

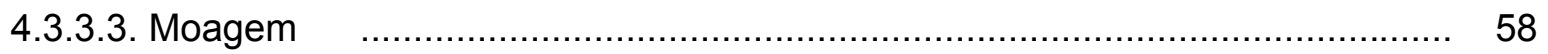

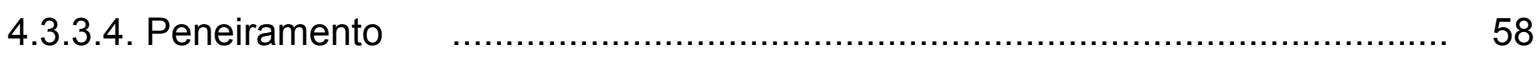

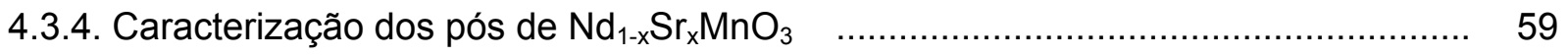

4.3.4.1. Cromatografia de absorção gasosa $\quad$ ….................................................. 59

4.3.4.2. Espectrometria de fluorescência de raios $X$ por energia dispersiva $\quad$........... 59

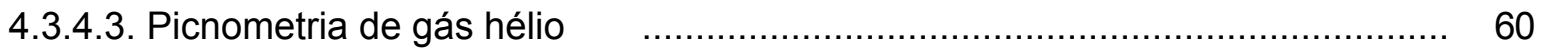


4.3.4.4. Análise granulométrica por espalhamento de feixes de laser

4.3.4.5. Análise de diâmetro médio utilizando o zetâmetro $\quad$.................................... 61

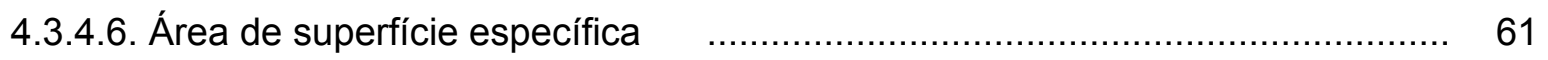

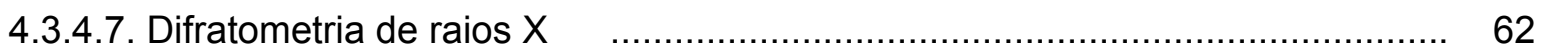

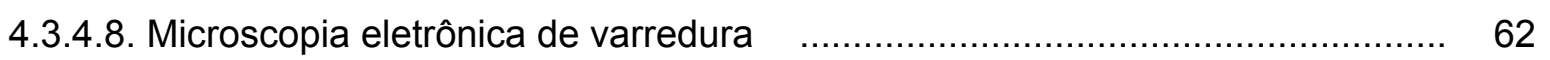

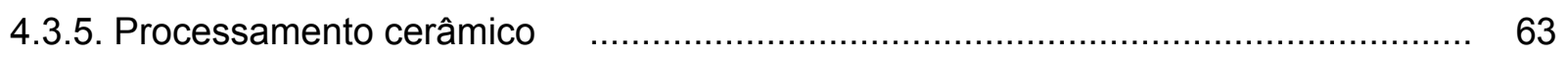

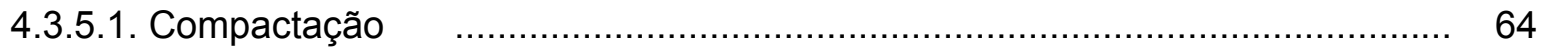

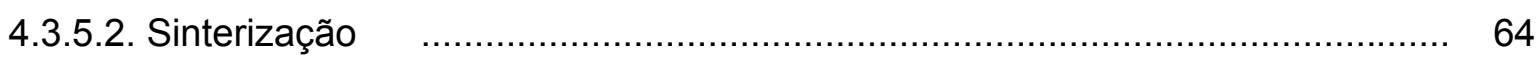

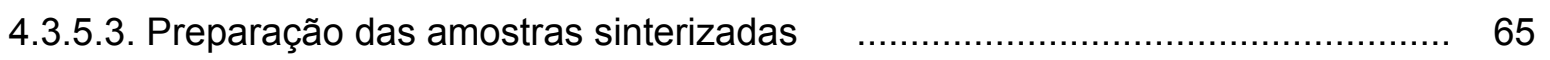

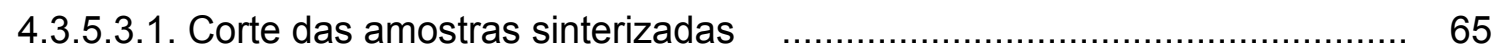

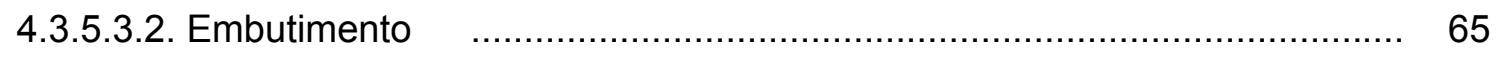

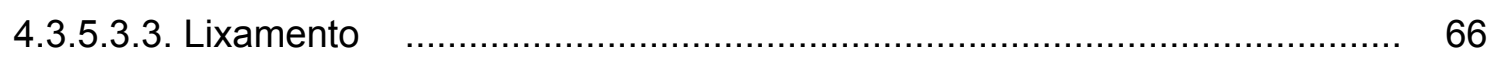

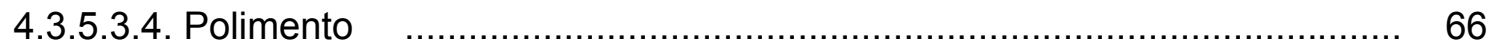

4.3.5.3.5. Tratamento térmico para revelação dos grãos $\quad$....................................... 66

4.3.6. Caracterização das cerâmicas a verde $\quad$...................................................... 66

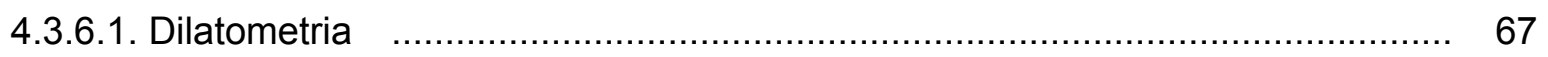

4.3.7. Caracterização das cerâmicas sinterizadas $\quad$.................................................... 67

4.3.7.1. Método de Determinação da Densidade geométrica a verde $\quad$................... 67

4.3.7.2. Método de Determinação da Densidade geométrica dos sinterizados $\quad$........ 68

4.3.7.3. Método de Determinação da Densidade aparente dos sinterizados $\quad$............ 68

4.3.7.4. Método de Determinação da Densidade teórica e da porosidade $\quad$............... 69

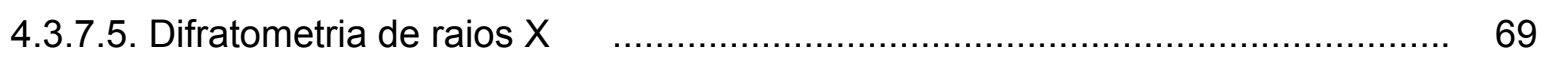

4.3.7.6. Microscopia eletrônica de varredura $\quad$.................................................. 69

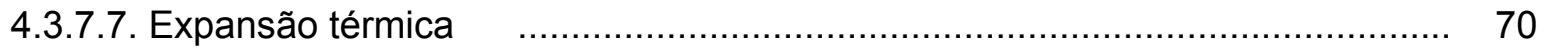

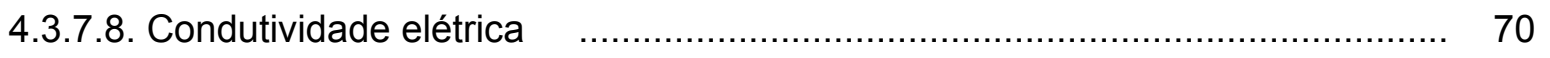

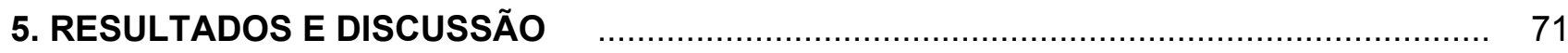

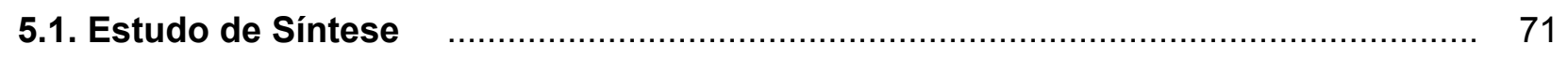

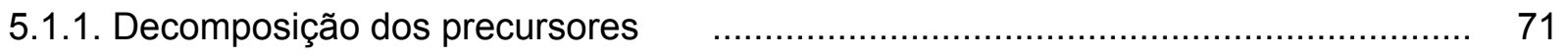

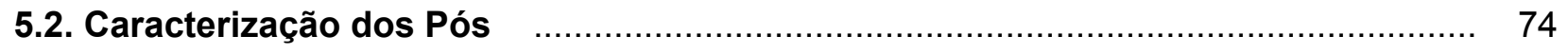

5.2.1. Avaliação do teor de carbono residual $\quad$ …................................................. 74

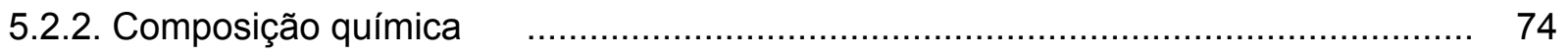




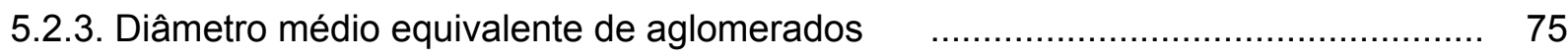

5.2.4. Diâmetro médio efetivo de aglomerados $\quad$................................................. 76

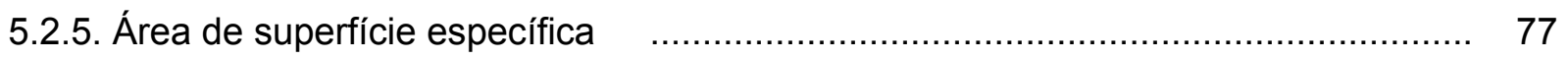

5.2.6. Diâmetro médio de partícula $\quad$ …............................................................ 78

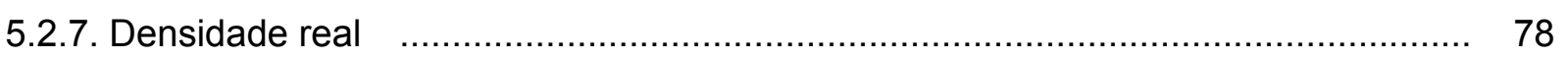

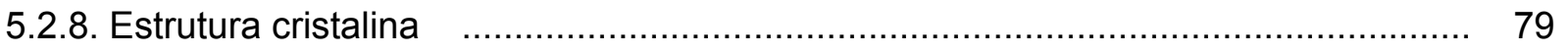

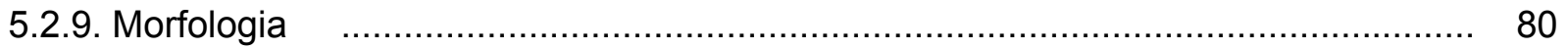

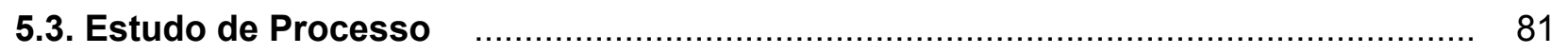

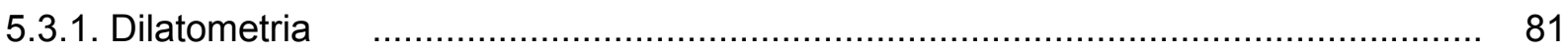

5.4. Caracterização das Cerâmicas $\quad$ …….............................................................. 83

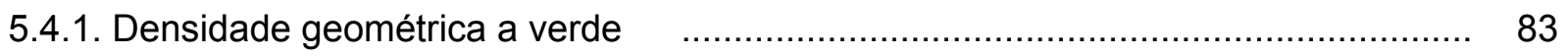

5.4.2. Densidade geométrica dos sinterizados $\quad$................................................. 83

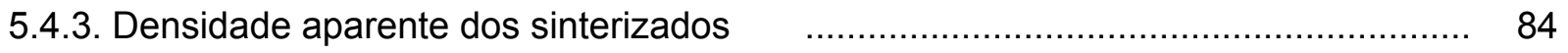

5.4.4. Densidade teórica e porosidade $\quad$...................................................................... 84

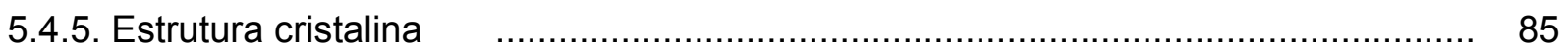

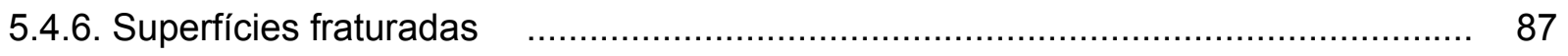

5.4.7. Superfícies fraturadas tratadas termicamente $\quad$.............................................. 90

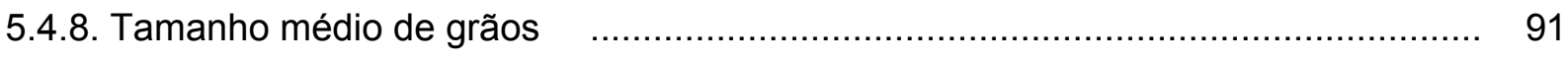

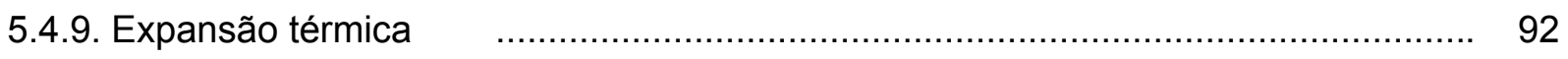

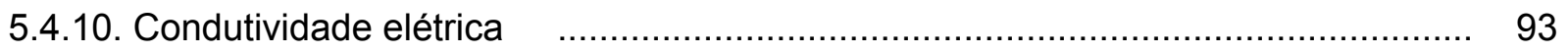

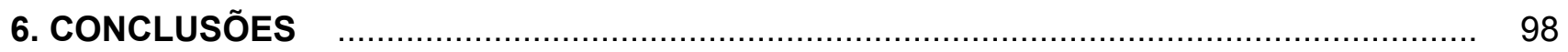

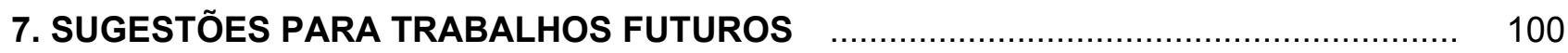

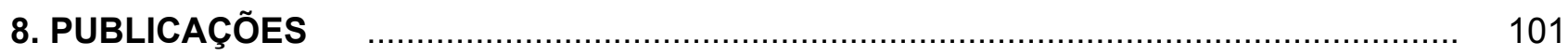

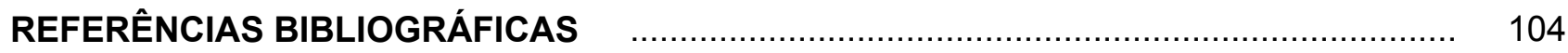




\section{LISTA DE TABELAS}

Tabela 3.1 Principais tecnologias de CaCs e suas características.

Tabela 4.1 Composição química e nomenclatura adotada para estudo do $\mathrm{Nd}_{1-\mathrm{x}} \mathrm{Sr}_{\mathrm{x}} \mathrm{MnO}_{3} \ldots .$.

Tabela 5.1 Perda de massa durante a ATG para as amostras de NSM.......................... 73

Tabela 5.2 Teor de carbono após as etapas de calcinação e tratamento............................ 74

Tabela 5.3 Valores obtidos por FRX e estequiometria real dos materiais em estudo........... 75

Tabela 5.4 Diâmetros médios equivalentes obtidos por distribuição granulométrica............ 76

Tabela 5.5 Diâmetros médios efetivos obtidos no zetâmetro............................................ 77

Tabela 5.6 Área superficial específica das amostras em estudo..................................... 77

Tabela 5.7 Diâmetros médios de partículas das amostras NSM10, NSM30 e NSM50......... 78

Tabela 5.8 Densidades reais das amostras de NSM.................................................... 78

Tabela 5.9 Estrutura cristalina e parâmetros de rede das amostras sintetizadas................. 79

Tabela 5.10 Valores das densidades geométricas a "verde" dos materiais em estudo........... 83

Tabela 5.11 Valores das densidades geométricas dos sinterizados................................... 83

Tabela 5.12 Valores das densidades aparentes dos materiais após sinterização.................. 84

Tabela $5.13 \quad$ Valores das porosidades calculadas........................................................ 85

Tabela $5.14 \quad$ TEC das amostras em estudo................................................................ 93

Tabela 5.15 Condutividade elétrica das amostras de NSM sinterizadas a $1200^{\circ} \mathrm{C} \ldots \ldots \ldots \ldots \ldots . . . . . .96$

Tabela 5.16 Energia de ativação das amostras de NSM sinterizadas a $1200{ }^{\circ} \mathrm{C} \ldots \ldots \ldots \ldots \ldots \ldots . . . . . . . .96$ 


\section{LISTA DE ILUSTRAÇÕES}

Figura 3.1

Figura 3.2

Figura 3.3

Figura 3.4

Figura 3.5

Figura 3.6

Figura 3.7

Figura 3.8

Figura 3.9

Figura 3.10

Figura 3.11

Figura 3.12

Figura 3.13

Figura 3.14

Figura 3.15

Figura 3.16

Figura 3.17

Figura 3.18

Figura 3.19

Figura 3.20

Figura 3.21

Figura 3.22

Figura 3.23

Figura 3.24

Representação ilustrativa do processo de eletrólise da água.

Representação ilustrativa mostrando que a eletrólise da água é reversível...... 05 Representação ilustrativa de uma das missões Apollo... 06 Ilustração para a compreensão conceitual de uma CaC.. 09

Representação ilustrativa de um stack de CaCs..... 10

Representação ilustrativa de um reformador para produção de hidrogênio. 11 Fluxograma ilustrativo de um processo de reforma externa. 13

Fluxograma ilustrativo de um processo de reforma interna. 13

Fluxograma ilustrativo de um processo de pré reforma externa. 14 Representação ilustrativa do funcionamento de uma CaC unitária.. 15 CaC com micro-turbina a gás (a) e eletrólise com painel solar (b)..... 16 Eficiência da CaC: Ciclo de Carnot (a), motores elétricos e turbinas (b)... 17 Estação de PAFCs instalada no Alasca.....

Esquema do funcionamento de uma SOFC unitária.. 34

Representação ilustrativa de um stack de SOFC 35

llustrações de uma SOFC planar retangular (a) e planar circular (b). 37 Ilustratação de uma SOFC tubular. 37

Ilustrações de uma SOFC monolítica (a) e segmentada (b)...... 38

llustração de módulo de SOFC industrial... 38

Representação ilustrativa da tripla fase reacional. 42 llustração representativa da estrutura perovskita.. 45

Aspecto da distorção da estrutura perovskita... 46

Problema encontrado na mistura de sólidos com utilização de óxidos. 47 Representação ilustrativa dos estágios da sinterização. 
Figura 5.1

Figura 5.2

Figura 5.3

Figura 5.4

Figura 5.5

Figura 5.6

Figura 5.7

Figura 5.8

Figura 5.9

Figura 5.10

Figura 5.11

Figura 5.12

Figura 5.13

Figura 5.14

Figura 5.15

Figura 5.16

Figura 5.17
Resultados da ATG/ATD para os pós de NSM10(a), NSM30(b) e NSM50(c)...

Distribuição granulométrica para as amostras de NSM. 75

Difratogramas obtidos por DRX dos pós de NSM10, NSM30 e NSM50 79

Micrografias dos pós de NSM10(a,b), NSM30(c,d) e NSM50(e,f). 81

Curvas de retração linear das amostras NSM10, NSM30 e NSM50..... 82

DRX das amostras sinterizadas de NSM10. 86

DRX das amostras sinterizadas de NSM30. 87

DRX das amostras sinterizadas de NSM50. 87

Micrografias obtidas por MEV, das pastilhas cerâmicas fraturadas e sinterizadas de NSM1011(a), NSM1012(b), NSM1013(c) e NSM1014(d)......... Micrografias obtidas por MEV, das pastilhas cerâmicas fraturadas e sinterizadas de NSM3011(a), NSM3012(b), NSM3013(c) e NSM3014(d)........ 88

Micrografias obtidas por MEV, das pastilhas cerâmicas fraturadas e sinterizadas de NSM1011(a), NSM1012(b), NSM1013(c) e NSM1014(d).

Micrografias obtidas por MEV, das pastilhas cerâmicas atacadas termicamente de NSM1011(a) e NSM1012(b).

Micrografias obtidas por MEV, das pastilhas cerâmicas atacadas termicamente de NSM3011(a) e NSM3012(b).

Micrografias obtidas por MEV, das pastilhas cerâmicas atacadas termicamente de NSM5011(a) e NSM5012(b).

Expansão térmica das amostras sinterizadas de NSM.

Resistividade elétrica para as amostras de NSM sinterizadas a $1200{ }^{\circ} \mathrm{C}$

94

Condutividade elétrica em função da temperatura (curva de Arrhenius) para as amostras de NSM sinterizadas a $1200^{\circ} \mathrm{C}$ 


\section{LISTA DE ABREVIATURAS E SIGLAS}

\begin{tabular}{|c|c|}
\hline$A F C$ & Alkaline Fuel Cell \\
\hline ANEEL & Agência Nacional de Energia Elétrica \\
\hline ANP & Agência Nacional do Petróleo \\
\hline$B C C$ & Business Communications Company \\
\hline $\mathrm{CaC}$ & Célula a Combustível \\
\hline $\mathrm{CaCs}$ & Células a Combustível \\
\hline CAPES & Coordenação de Aperfeiçoamento de Pessoal de Nível Superior \\
\hline CELESC & Concessionária de Energia de Santa Catarina \\
\hline CEMIG & Companhia Energética de Minas Gerais \\
\hline CGEE & Centro de Gestão e Estudos Estratégicos \\
\hline CIETEC & Centro Incubador de Empresas Tecnológicas \\
\hline CNEN & Comissão Nacional de Energia Nuclear \\
\hline CNPq & Conselho Nacional de Desenvolvimento Científico e Tecnológico \\
\hline COOPE & Coordenação de Programas de Pós-Graduação em Engenharia \\
\hline Copel & Companhia Paranaense de Energia \\
\hline cSOFC & circular Solid Oxide Fuel Cell \\
\hline CT-Energ & Fundo Setorial de Energia \\
\hline CT-Infra & Fundo Setorial de Infra-Estrutura \\
\hline CT-Petro & Fundo Setorial do Petróleo e Gás Natural \\
\hline$D B F C$ & Direct Borohydride Fuel Cell \\
\hline$D E F C$ & Direct Ethanol Fuel Cell \\
\hline$D M F C$ & Direct Methanol Fuel Cell \\
\hline EGFC & Electro-Galvanic Fuel Cell \\
\hline EMTU & Empresa Metropolitana de Transportes Urbanos de São Paulo \\
\hline EUA & Estados Unidos da América \\
\hline FAFC & Formic Acid Fuel Cell \\
\hline FAPESP & Fundação de Amparo à Pesquisa do Estado de São Paulo \\
\hline FCs & Fuel Cells \\
\hline FINEP & Financiadora de Estudos e Projetos \\
\hline
\end{tabular}


GDC Céria Dopada com Gadolínia

HTSOFC Hight Temperature Solid Oxide Fuel Cell

IEE Instituto de Eletrotécnica e Energia

INEP Instituto Nacional de Eletrônica de Potência

IPEN Instituto de Pesquisas Energéticas e Nucleares

IPT Instituto de Pesquisas Tecnológicas

ITSOFC Intermediate Temperature Solid Oxide Fuel Cell

LABH2 Laboratório de Hidrogênio

Lactec Instituto de Tecnologia para o Desenvolvimento

LC Cromito de Lantânio

LNLS Laboratório Nacional de Luz Síncrotron

LSM Manganito de Lantânio Dopado com Estrôncio

MCT Ministério da Ciência e Tecnologia

MFC Microbial Fuel Cell

MHFC Metal Hydride Fuel Cell

mSOFC monilitic Solid Oxide Fuel Cell

NASA National Aeronautics And Space Administration

NSM Manganito de Neodímio Dopado com Estrôncio

PAFC Phosphoric Acid Fuel Cell

PEC Photoelectrochemical Cell

PEMFC Proton Exchange Membrane Fuel Cell

PETROBRAS Petróleo Brasileiro S.A.

PCFC Protonic Ceramic Fuel Cell

PNDU Programa das Nações Unidas para o Desenvolvimento

PROCaC Programa Brasileiro de Sistemas Células a Combustível

$\mathrm{PROH} 2 \quad$ Programa de Ciência, Tecnologia e Inovação para a Economia do Hidrogênio

pSOFC planar Solid Oxide Fuel Cell

Rede PaCOS Rede de Pilhas a Combustível de Óxido Sólido

RFC Reversible Fuel Cell

SDC Céria Dopada com Samária

SI Sistema Internacional de Unidades

SOFC Solid Oxide Fuel Cell 


\begin{tabular}{ll} 
sSOFC & segmented Solid Oxide Fuel Cell \\
TECPAR & Instituto de Tecnologia do Paraná \\
TPBL & three phase boundary line \\
tSOFC & tubular Solid Oxide Fuel Cell \\
UNICAMP & Universidade Estadual de Campinas \\
UFMG & Universidade Federal de Minas Gerais \\
UFPR & Universidade Federal do Paraná \\
UFRGS & Universidade Federal do Rio Grande do Sul \\
UFRJ & Universidade Federal do Rio de Janeiro \\
UFRN & Universidade Federal do Rio Grande do Norte \\
UFSC & Universidade Federal de Santa Catarina \\
UFSCar & Universidade Federal de São Carlos \\
UNIVALI & Universidade do Vale do Itajaí \\
USF & Universidade São Francisco \\
USP & Universidade de São Paulo \\
YSZ & Zircônia Estabilizada com Ítria \\
ZAFC & Zinc-Air Fuel Cell \\
& \\
\hline
\end{tabular}




\section{LISTA DE SÍMBOLOS}

\begin{tabular}{|c|c|c|c|}
\hline $\mathrm{Al}$ & Alumínio & $\mathrm{O}_{2}$ & Gás oxigênio \\
\hline C & Carbono & $\%$ & Porcentagem \\
\hline $\mathrm{CH}_{4}$ & Gás metano & $\mathrm{ppm}$ & Parte por milhão \\
\hline Co & Cobalto & $\mathrm{Pt}$ & Platina \\
\hline $\mathrm{cm}$ & Centímetro & $\mathrm{Sr}$ & Estrôncio \\
\hline $\mathrm{CO}$ & Monóxido de carbono & Sn & Estanho \\
\hline $\mathrm{CO}_{2}$ & Dióxido de carbono & W & Tungstênio \\
\hline $\mathrm{Cr}$ & Cromo & W & Watt \\
\hline$e^{-}$ & Elétron & $\mathrm{Zn}$ & Zinco \\
\hline $\mathrm{Fe}$ & Ferro & $\mathrm{Zn}\left(\mathrm{C}_{18} \mathrm{H}_{35} \mathrm{O}_{2}\right)_{2}$ & Estearato de zinco \\
\hline $\mathrm{H}^{+}$ & Íon positivo de hidrogênio & $\mu \mathrm{m}$ & Mícron \\
\hline $\mathrm{H}_{2}$ & Gás hidrogênio & ${ }^{\circ} \mathrm{C}$ & Graus Celsius \\
\hline $\mathrm{HCl}$ & Ácido clorídrico & & \\
\hline $\mathrm{He}$ & Hélio & & \\
\hline $\mathrm{H}_{2} \mathrm{O}$ & Água & & \\
\hline $\mathrm{HNO}_{3}$ & Ácido nítrico & & \\
\hline $\mathrm{H}_{2} \mathrm{SO}_{4}$ & Ácido sulfúrico & & \\
\hline $\mathrm{KOH}$ & Hidróxido de Potássio & & \\
\hline $\mathrm{kW}$ & KiloWatt & & \\
\hline La & Lantânio & & \\
\hline $\mathrm{Mn}$ & Manganês & & \\
\hline MW & Megawatt & & \\
\hline $\mathrm{Ni}$ & Níquel & & \\
\hline $\mathrm{NaOH}$ & Hidróxido de sódio & & \\
\hline $\mathrm{Nd}$ & Neodímio & & \\
\hline NOx & Óxido de nitrogênio & & \\
\hline $\mathrm{O}^{2-}$ & íons negativo de oxigênio & & \\
\hline
\end{tabular}




\section{INTRODUÇÃO}

O modelo atual da produção de energia elétrica em todo o mundo, dependente principalmente de jazidas de combustíveis fósseis, esgota os recursos naturais e deteriora as condições ambientais, alterando todo o ecossistema. Estes combustíveis não são renováveis e seus beneficiamentos e usos geram contaminantes atmosféricos, como o dióxido de carbono $\left(\mathrm{CO}_{2}\right)$, principal responsável pela ocorrência do efeito estufa, provocando alteração na temperatura média e aquecimento de todo o planeta. Além disso, existem fatores estratégicos e econômicos que devem ser considerados, pois suas jazidas estão concentradas em poucas regiões do mundo, em nações com problemas políticos e sociais, assim como os preços estão sujeitos a grandes instabilidades ${ }^{(1)}$.

As usinas hidroelétricas, apesar de não poluírem como as termoelétricas e não gerarem lixo nocivo ao meio ambiente e à humanidade como as nucleares, necessitam de grande área física para armazenamento de água, interferindo de forma significativa para o desequilíbrio da fauna, da flora e também das populações que vivem nas regiões onde estão sendo implementadas ${ }^{(1,2)}$.

Com isso, a energia de forma descentralizada, ou seja, no próprio local de utilização (ou no local mais próximo), está ganhando cada vez mais destaque, pois economiza custos com linhas de transmissão e distribuição, e proporciona uma solução otimizada energeticamente, economicamente e ecologicamente. A energia descentralizada ou distributiva sempre existiu, porém, a geração de energia em pequena escala já está competindo com a geração centralizada. A melhora do padrão de vida da humanidade requer o aperfeiçoamento da qualidade da energia fornecida e dos serviços que podem ser oferecidos, dentro de um processo de crescimento sustentável ${ }^{(1,3)}$.

Por estes motivos, uma nova era está se iniciando, para produzir energia elétrica extremamente confiável, independente de recursos esgotáveis, de maior qualidade, renovável e não poluente. As novas tecnologias da chamada "microenergia" e que incluem microturbinas a gás e a vapor, energia solar, eólica, 
geotérmica, marés, ondas (mar), biomassa e Células a Combustível - CaCs (Fuel Cells) estão ganhando cada vez mais destaques ${ }^{(4,5)}$.

De todas as novas tecnologias, as CaCs são as que possuem um maior destaque para geração de energia de forma sustentável ${ }^{(4)}$. Existem atualmente várias tecnologias, mas as que operam em temperaturas entre $600 \mathrm{e}$ $1000^{\circ} \mathrm{C}$, como as Células a Combustível de Óxido Sólido (SOFCs), são as que possuem maiores perspectivas futuras para aplicações estacionárias de geração de energia elétrica. Em particular, as SOFCs possuem vantagens como alta eficiência e reforma interna do combustível, tendo grande importância para aplicação em unidades estacionárias de médio e grande porte ${ }^{(5,6)}$.

Dentro de todo esse contexto, o manganito de neodímio dopado com estrôncio $\left(\mathrm{Nd}_{1-x} \mathrm{Sr}_{x} \mathrm{MnO}_{3}-\mathrm{NSM}\right)$, é um material cerâmico alternativo para aplicação como catodo nas SOFCs que operam entre 500 e $800{ }^{\circ} \mathrm{C}{ }^{(7,8)}$. Nos últimos anos, o grande interesse dos pesquisadores em relação aos catodos se deve a características como: boa estabilidade química e térmica, alta atividade catalítica para redução do oxigênio, coeficiente de expansão térmica similar aos eletrólitos sólidos e boa condutividade elétrica ${ }^{(9,10)}$.

A dopagem do manganito de neodímio $\left(\mathrm{NdMnO}_{3}\right)$ com estrôncio $(\mathrm{Sr})$, aumenta a condutividade elétrica e melhora a estabilidade química ${ }^{(7,8)}$. Segundo MINH ${ }^{(9,10)}$, o Sr é o elemento preferencialmente escolhido como dopante, pois melhora a expansão térmica e permite maior condutividade eletrônica, devido à formação de cátions $\mathrm{Mn}^{4+}$ e substituição de $\mathrm{Nd}^{3+}$ por $\mathrm{Sr}^{2+}$.

Portanto, os estudos de obtenção do NSM com composição adequada para uso como catodo na SOFC é de fundamental importância. As concentrações molares de $\mathrm{Sr}$ mais estudadas variam entre $0,05 \leq \mathrm{x} \leq 0,50^{(7,8)}$. A literatura apresenta diferentes rotas de síntese para obtenção de NSM, sendo citadas principalmente a mistura de sólidos, citratos e reação por combustão ${ }^{(11-13)}$.

Em face destas considerações, no presente trabalho foi estudada a síntese do material catódico NSM utilizando a técnica de mistura de sólidos (reações no estado sólido) ${ }^{(8)}$. Desta forma, pretende-se colaborar para o avanço do conhecimento no processo de obtenção de um material cerâmico com características adequadas para uso como catodo em SOFCs, estudando principalmente, a influência do dopante $\mathrm{Sr}$ no comportamento de sinterização e nas características térmicas e elétricas do manganito de neodímio. 


\section{OBJETIVOS}

Considerando o programa brasileiro de políticas voltadas ao aproveitamento energético, principalmente com relação às diferentes formas alternativas de geração de energia elétrica, mais especificadamente as CaCs ${ }^{(14)}$, este trabalho de mestrado tem como principal objetivo, estudar a obtenção e a caracterização do $\mathrm{Nd}_{1-\mathrm{x}} \mathrm{Sr}_{\mathrm{x}} \mathrm{MnO}_{3}$ - NSM (Manganito de Neodímio Dopado com Estrôncio) e, como objetivos específicos:

- A síntese do NSM pela técnica de reação no estado sólido para concentrações molares iguais a $x=0,10$ (NSM10), $x=0,30$ (NSM30) e $x=$ 0,50 (NSM50). Estas concentrações foram definidas de acordo com a literatura ${ }^{(10,13,15)}$, pois valores maiores que " $x=0,50$ " interferem de forma negativa nas propriedades elétricas e valores menores que " $x=0,10$ " não são suficientes para sintetizar o material com as características adequadas para aplicação como um componente catódico em SOFCs.

- O processamento dos pós obtidos por esta técnica para a confecção de pastilhas cerâmicas.

- A caracterização dos pós e das pastilhas cerâmicas empregando diversas análises (química, física e microestrutural).

- Avaliar a influência do dopante estrôncio na composição química, porosidade, estrutura cristalina e propriedades térmica e elétrica do NSM. 


\section{REVISÃO DA LITERATURA}

Antes de abordar o tema proposto, é importante informar que o termo em inglês "Fuel Cells" (FCs) possui diversas traduções dentro da língua portuguesa. Algumas traduções como "Células a Combustível", "Células de Combustíveis", "Células Combustíveis", "Pilhas a Combustível", "Pilhas de Combustíveis" e "Células de Energia" foram encontradas em diversos artigos, livros e WebSites. Entretanto, considerou-se que o termo "Células a Combustível (CaCs)" é o mais coerente, visto que representa a tradução mais adequada do inglês, além de possuir a correta semântica ${ }^{1}$ das palavras, pois são células que funcionam com a presença de um determinado combustível.

A Revisão da Literatura apresenta de forma clara e objetiva toda a teoria envolvida neste trabalho, por isso, o texto está escrito da forma mais didática possível, para que esse material possa contribuir com futuras pesquisas e estudos. É importante destacar que, para quem não é familiarizado com os assuntos aqui discutidos, a leitura e compreensão deste capítulo é de grande importância para o correto entendimento de toda a dissertação.

\subsection{Células a Combustível}

\subsubsection{Evolução histórica}

As CaCs são conhecidas pela ciência há mais de 150 anos. Embora tenham sido consideradas algumas das curiosidades do século XIX, elas foram alvos de intensas pesquisas somente durante a Segunda Guerra Mundial ${ }^{(16,17)}$.

Como toda nova tecnologia considerada promissora, a $\mathrm{CaC}$ teve o seu início de pesquisas e fabricação exclusivamente para aplicações militares e posteriormente em projetos espaciais ${ }^{(16,17)}$.

\footnotetext{
${ }^{1}$ Estudo da linguagem humana do ponto de vista do significado das palavras e dos enunciados.
} 
Por volta de 1800, os cientistas britânicos WILLIAM NICHOLSON e, ANTHONY CARLISLE descreveram o processo (Figura 3.1) de utilizar a energia elétrica (eletricidade) para decompor a água $\left(\mathrm{H}_{2} \mathrm{O}\right)$ em gás hidrogênio $\left(\mathrm{H}_{2}\right)$ e gás oxigênio $\left(\mathrm{O}_{2}\right)$. Este processo ficou conhecido como "eletrólise da água" ${ }^{(16,17)}$.

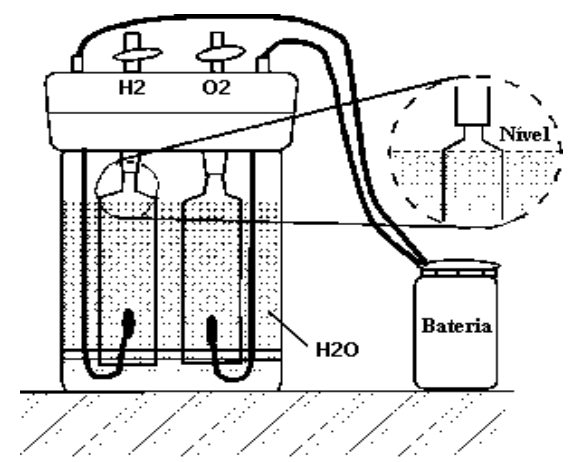

Figura 3.1 - Representação ilustrativa do processo de eletrólise da água ${ }^{(16)}$.

A primeira suposta CaC foi construída em 1801 por HUMPHREY DAVY, que realizou estudos em eletroquímica utilizando carbono (C) e ácido nítrico $\left(\mathrm{HNO}_{3}\right)$. O princípio das $\mathrm{CaCs}$ foi descoberto e elaborado por CHRISTIAN FRIEDRICH SCHÖNBEIN em $1838^{(5,16,17)}$.

De acordo com a história, os primeiros estudos com as CaCs se iniciaram efetivamente com o advogado e cientista inglês WILLIAM ROBERT GROVE em 1839. Ele descobriu que a eletrólise da água em ácido sulfúrico $\left(\mathrm{H}_{2} \mathrm{SO}_{4}\right)$ diluído é reversível. Em outras palavras, ele teve uma grande idéia durante os seus experimentos com a eletrólise, imaginando de que forma seria o processo inverso desta reação, ou seja, reagir gás $\mathrm{H}_{2}$ com gás $\mathrm{O}_{2}$, para formar vapor de $\mathrm{H}_{2} \mathrm{O}$ e gerar eletricidade (Figura 3.2) ${ }^{(5,16,17)}$.

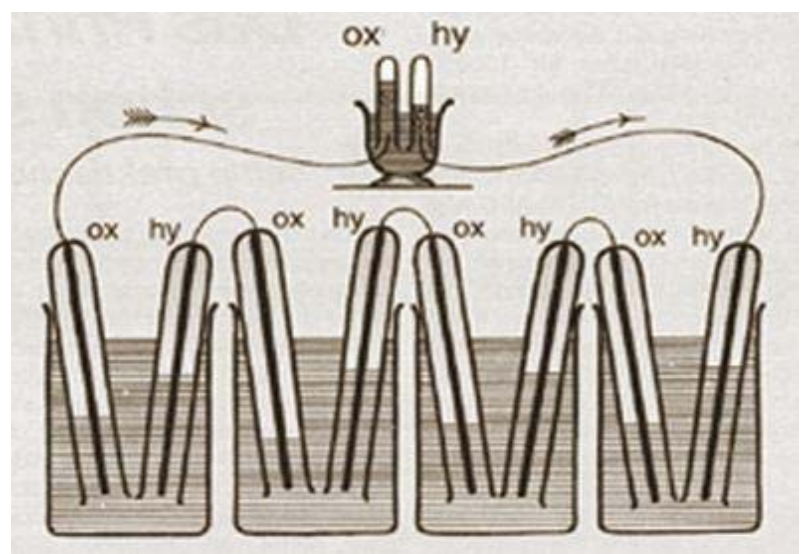

Figura 3.2 - Representação ilustrativa mostrando que a eletrólise da água é reversível ${ }^{(5)}$. 
O princípio de funcionamento das CaCs é, portanto, o inverso do processo de eletrólise da água. O termo "Célula a Combustível" foi empregado pela primeira vez por LUDWIG MOND e CHARLES LANGER em $1889^{(16,17) .}$

O cientista e fundador do campo da físico-química, FRIEDRICH WILHELM OSTWALD, contribuiu com muitas das teorias existentes na área. Em 1893, determinou experimentalmente as funções dos vários componentes de uma $\mathrm{CaC}$. Na primeira metade do século $X X$, o cientista suíço EMIL BAUR, conduziu grande quantidade de pesquisas com diferentes tecnologias de $\mathrm{CaCs}{ }^{(16,17)}$.

No final dos anos 1930, FRANCIS THOMAS BACON começou pesquisando a $\mathrm{CaC}$ de eletrólito alcalino (Alkaline Fuel Cell - AFC) operando com alta pressão e obtendo resultados interessantes. Durante a Segunda Guerra Mundial, BACON trabalhou no desenvolvimento de células que poderiam ser utilizadas na frota de submarinos da marinha inglesa e, em 1958, demonstrou uma $A F C$ utilizando um eletrodo de aproximadamente $25,4 \mathrm{~cm}$ de diâmetro ${ }^{(16,17)}$.

Embora fossem extremamente caras, as CaCs de BACON provaram ser confiáveis para atrair a atenção de uma grande empresa da época. Esta empresa se uniu com a Energy Conversion, que tinha BACON como consultor, e licenciou o trabalho dele para ser utilizado no desenvolvimento de um sistema de geração de energia elétrica para as missões espaciais Gemini e Apollo (Figura 3.3) da NASA (National Aeronautics And Space Administration) ${ }^{(16,17) .}$

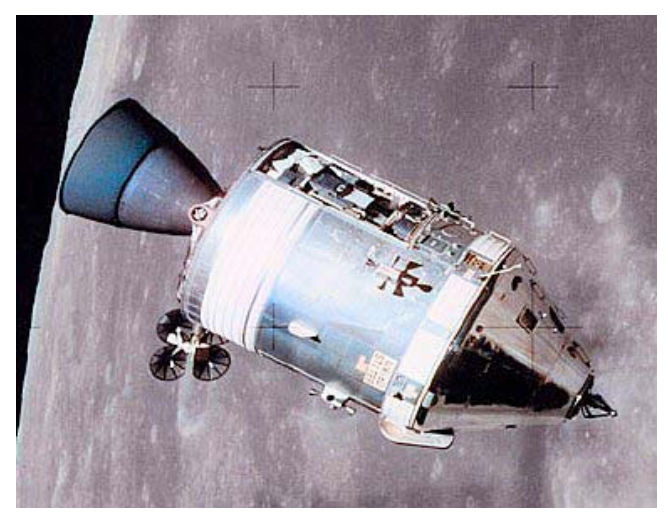

Figura 3.3 - Representação ilustrativa de uma das missões $A p o l l{ }^{(18)}$.

Após estas missões espaciais, foram paralisadas as construções de novas AFCs e tornou-se claro, levando em conta este tipo de célula, que a sua comercialização tinha como principais obstáculos principalmente o alto custo e a pequena vida útil ${ }^{(16,17)}$. 
As CaCs são utilizadas para gerarem energia elétrica para os equipamentos eletro eletrônicos adaptados em ônibus e em módulos de explorações espaciais, além de produzir $\mathrm{H}_{2} \mathrm{O}$ para consumo da tripulação ${ }^{(5)}$.

Na década de 1970, houve grande interesse nas pesquisas com CaCs. O sistema alcalino, que alcançou o nível máximo de seu desenvolvimento durante os programas espaciais mencionados, foi substituído pelo sistema ácido fosfórico (Phosphoric Acid Fuel Cell - PAFC) que, por sua vez, era mais indicado na época para aplicações estacionárias de produção de energia elétrica ${ }^{(5,16,17)}$.

Na década de 1980 e início dos anos 1990, devido à sua melhor eficácia e possibilidade de co-produção de calor (operação a temperaturas elevadas), os sistemas das CaCs de carbonato fundido (Molten Carbonate Fuel Cell - MCFC) e de óxido sólido (Solid Oxide Fuel Cell - SOFC) tiveram um acelerado desenvolvimento, porém as vidas úteis extremamente curtas resultaram em muitos problemas que ainda precisam ser resolvidos ${ }^{(5,16,17)}$.

Ainda nos anos 1990, aconteceu uma reviravolta na tecnologia. As CaCs de membrana polimérica trocadora de prótons (Proton Exchange Membrane Fuel Cell - PEMFC) reapareceram no meio científico como um grande atrativo. Este sistema já existia desde 1960, mas não resultou aplicável para os projetos espaciais. Com o desenvolvimento de novas membranas e também de catalisadores, foram obtidas elevadas densidades de corrente e seu tempo de vida de operação aumentou consideravelmente ${ }^{(5,16,17)}$.

Atualmente, as CaCs apresentam evolução em durabilidade, diminuição de custos e são algumas das principais soluções energéticas ambientalmente limpas. O assunto é bastante discutido e difundido, tanto internacionalmente como nacionalmente, devido à geração de energia distribuída e à utilização do $\mathrm{H}_{2}$ como o combustível ideal, pois é considerado o "vetor" energético do futuro ${ }^{(19,20)}$.

As CaCs e $\mathrm{O}_{2}$ estão fortemente correlacionados, pois além das pesquisas e desenvolvimentos das células, deve-se também um grande estudo ao combustível $\mathrm{H}_{2}$, por não ser poluente e por ser possível a sua produção a partir de diversas fontes de energias renováveis. É só uma questão de tempo para que as CaCs estejam fazendo parte da vida das pessoas, como ocorreu anteriormente com os computadores pessoais e telefones celulares ${ }^{(20)}$. 


\subsubsection{Breve evolução no Brasil}

Desde o final da década de 1970, algumas atividades na área de CaCs no Brasil vêm sendo desenvolvidos direta ou indiretamente. O Instituto de Química da USP (Universidade de São Paulo) localizado em São Carlos foi o precursor em estudos relacionados às CaCs. Várias instituições, como a UFRJ (Universidade Federal do Rio de Janeiro), o IPT (Instituto de Pesquisas Tecnológicas) e o grupo de eletroquímica da UFSCar (Universidade Federal de São Carlos) se dedicaram ao estudo deste tipo de tecnologia ${ }^{(14,23,27)}$.

Em meados de 1998, iniciou-se no IPEN (Instituto de Pesquisas Energéticas e Nucleares), pertencente à CNEN (Comissão Nacional de Energia Nuclear), o estudo e desenvolvimento de duas CaCs: A PEMFC e a SOFC. Desde o início, o programa de CaCs do IPEN apresenta crescimento considerável e destaca o instituto como um centro de excelência na área ${ }^{(21)}$.

Os reflexos de ações conduzidas no exterior para o desenvolvimento das $\mathrm{CaCs}$, são observados dentro de iniciativa do MCT (Ministério da Ciência e Tecnologia) e do CGEE (Centro de Gestão e Estudos Estratégicos), onde foi criado o PROCaC (Programa Brasileiro de Sistemas Células a Combustível), que a partir de 2005 passou a se chamar PROH2 (Programa de Ciência, Tecnologia e Inovação para a Economia do Hidrogênio) ${ }^{(14,21)}$.

Neste programa estão envolvidas agências financiadoras como o MCT, FINEP (Financiadora de Estudos e Projetos), CNPq (Conselho Nacional de Desenvolvimento Científico e Tecnológico), FAPESP (Fundação de Amparo à Pesquisa do Estado de São Paulo), CAPES (Coordenação de Aperfeiçoamento de Pessoal de Nível Superior), entre outras ${ }^{(21)}$.

Estão também envolvidos fundos setoriais como o CT-Petro (Fundo Setorial do Petróleo e Gás Natural), CT-Energ (Fundo Setorial de Energia) e CT-Infra (Fundo Setorial de Infra-Estrutura); companhias incubadas como a Electrocell $^{2}$ e a NovoCell ${ }^{3}$; universidades federais e estaduais como a USP, UNICAMP (Universidade de Campinas), UFRJ, UFPR (Universidade Federal

\footnotetext{
${ }^{2}$ A Electrocell é uma empresa brasileira de desenvolvimento de sistemas e periféricos associados à tecnologia de $\mathrm{CaC}$, principalmente a $P E M F C$.

${ }^{3}$ A NovoCell Sistemas de Energia S.A. é uma empresa brasileira de desenvolvimento e produção de $\mathrm{CaCs}$ de baixo peso, volume e custos de montagem. Atualmente, o foco são as PEMFCs que operam em baixa temperatura para utilização no setor de telecomunicações, setor de prestação de serviços de internet e em setores industriais.
} 
do Paraná), UFRGS (Universidade Federal do Rio Grande do Sul), UFMG (Universidade Federal de Minas Gerais) e UFRN (Universidade Federal do Rio Grande do Norte); institutos de pesquisas como o IPEN, O IPT e o IEE (Instituto de Eletrotécnica e Energia), todos os três localizados no campus da USP, na cidade de São Paulo ${ }^{(20,21)}$.

Por fim, temos também as empresas que trabalham com petróleo e energia elétrica, como a PETROBRAS (Petróleo Brasileiro S.A.), CEMIG (Companhia Energética de Minas Gerais), ANP (Agência Nacional do Petróleo) e a ANEEL (Agência Nacional de Energia Elétrica) ${ }^{(14,20)}$.

\subsubsection{O conceito}

As CaCs são dispositivos eletroquímicos que convertem diretamente a energia de reações químicas, utilizando a combinação entre oxidante e combustível, para gerar energia elétrica, energia térmica e vapor de água ${ }^{(5,16,17)}$.

A estrutura básica de uma $\mathrm{CaC}$ unitária consiste em uma camada de eletrólito em contato com dois eletrodos, um de cada lado e ambos porosos. Em uma CaC típica, o anodo (eletrodo negativo) é alimentado continuamente com um combustível, normalmente o hidrogênio, enquanto o catodo (eletrodo positivo) recebe um oxidante, usualmente o oxigênio ou ar. As reações eletroquímicas que ocorrem nos eletrodos produzem o que conhecemos como corrente elétrica ${ }^{(16,17)}$. A Figura 3.4 apresenta a ilustração de uma CaC unitária gerando energia elétrica para uma determinada aplicação ${ }^{(5)}$.

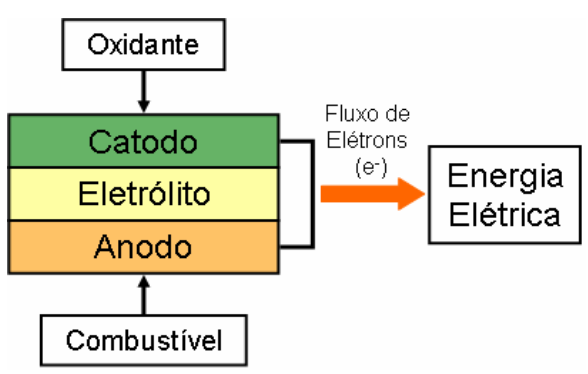

Figura 3.4 - llustração para a compreensão conceitual de uma $\mathrm{CaC}^{(5)}$.

Embora tenham o mesmo princípio de funcionamento das pilhas e baterias tradicionais, ou seja, a energia gerada pela reação química entre os seus reagentes é transformada diretamente em energia elétrica, as CaCs se diferem 
pelo fato de seus eletrodos serem alimentados continuamente por um oxidante e por um combustível, respectivamente, podendo ser a energia produzida atualmente da ordem de $1 \mathrm{MW}$ (1MegaWatt) de potência elétrica ${ }^{(16,17)}$.

As CaCs, de forma geral, não possuem aplicações práticas utilizando somente células unitárias, elas devem ser conectadas em série para produzir voltagens adequadas para aplicações comerciais. Uma série de CaCs recebe a denominação de stack (empilhamento). Um componente comumente chamado de interconector (separador bipolar) conecta o anodo de uma célula ao catodo da célula seguinte. Os stacks (Figura 3.5) podem ser configurados em série, em paralelo ou ambos, dependendo da aplicação a que serão solicitados ${ }^{(5,16,17)}$.

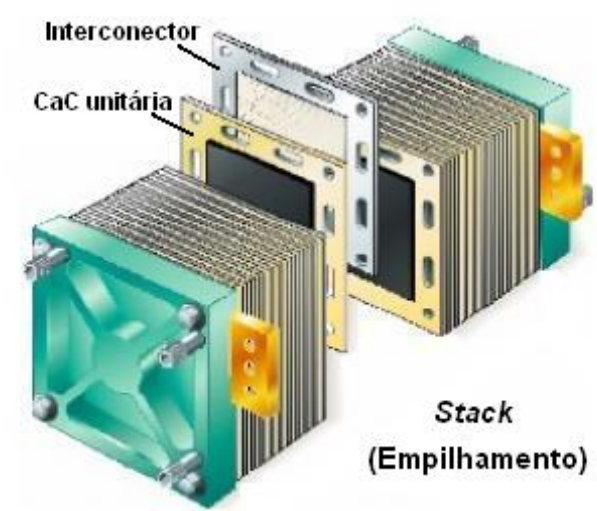

Figura 3.5 - Representação ilustrativa de um stack de CaCs ${ }^{(5)}$.

\subsubsection{O combustível hidrogênio}

Antes de dar continuidade ao assunto "células a combustível", é importante conhecer um pouco mais sobre o hidrogênio $\left(\mathrm{H}_{2}\right)$, assim como alguns combustíveis alternativos que também podem ser utilizados nas $\mathrm{CaCs}$.

O combustível ideal para se utilizar nas CaCs é realmente o $\mathrm{H}_{2}$, pois é o elemento mais abundante do Universo, constituindo $75 \%$ da sua massa e $90 \%$ de seus átomos. Encontra-se em grande quantidade nas estrelas e nos planetas gigantes gasosos, como Júpiter e Saturno, entretanto, na atmosfera terrestre é encontrado em seu estado puro, em uma quantidade muito pequena, aproximadamente $1 \mathrm{ppm}$ (1 parte por milhão) em volume ${ }^{(20)}$.

Uma fonte comum e abundante de $\mathrm{H}_{2}$ em nosso planeta é a água, composta por dois átomos de hidrogênio e um de oxigênio. Além da água, o $\mathrm{H}_{2}$ é 
encontrado em praticamente todos os compostos orgânicos e inorgânicos que conhecemos, sendo que as fontes mais importantes são as substâncias formadas principalmente de carbono e hidrogênio, conhecidas como hidrocarbonetos, e que incluem todas as formas de vida existentes, além dos combustíveis fósseis e também do gás natural ${ }^{(20)}$.

O gás metano $\left(\mathrm{CH}_{4}\right)$, produto da decomposição orgânica, está adquirindo crescente importância como fonte de $\mathrm{H}_{2}$. Além da água e do $\mathrm{CH}_{4}, \circ \mathrm{H}_{2}$ pode ser obtido também do etanol (álcool), do metanol, do lixo urbano e rural, da biomassa, de algas e bactérias, entre outros ${ }^{(5,22)}$. Para extrair o $\mathrm{H}_{2}$ é utilizado um equipamento conhecido como reformador (Figura 3.6) ${ }^{(16)}$.

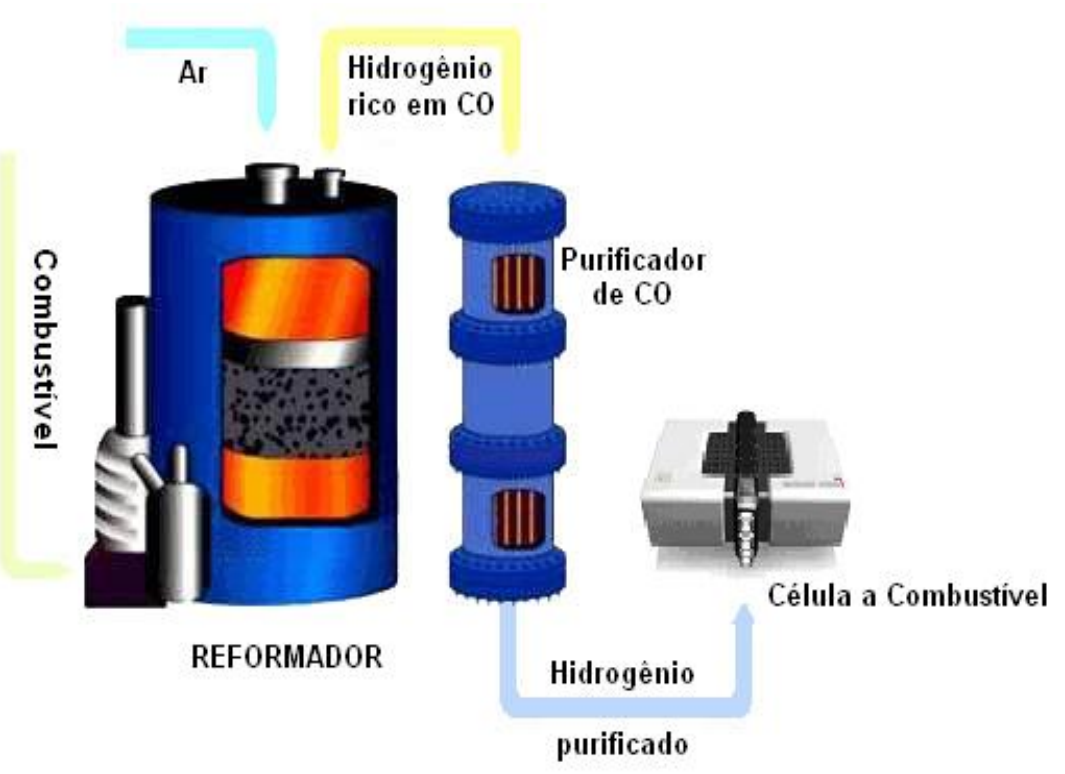

Figura 3.6 - Representação ilustrativa de um reformador para produção de hidrogênio ${ }^{(16)}$.

Atualmente, $\mathrm{o}_{2}$ é obtido principalmente das seguintes formas ${ }^{(20)}$ :

- Eletrólise da água;

- Reação de hidrocarbonetos com vapor de água;

- Ataque de metais com hidróxido de sódio $(\mathrm{NaOH})$ e potássio $(\mathrm{KOH})$;

- Ataque de metais (Zinco - Zn e Alumínio - $\mathrm{Al}$ ) com ácidos sulfúrico ou ácido clorídrico $(\mathrm{HCl})$. 
As CaCs em si não produzem resíduos tóxicos ou nocivos ao meio ambiente, mas não se pode dizer o mesmo da produção de hidrogênio. $\mathrm{O} \mathrm{H}_{2}$ não é encontrado puro em nossa natureza e a maneira de obtê-lo é a partir de outras moléculas. O petróleo é formado por hidrocarbonetos, mas conseguir $\mathrm{H}_{2}$ a partir da reforma de compostos derivados do petróleo tem como subproduto o carbono, que reage com $\mathrm{O} \mathrm{O}_{2}$ atmosférico, resultando em dióxido de carbono $\left(\mathrm{CO}_{2}\right)$ e gerando compostos que causam a poluição atmosférica. Outra opção é utilizar a água como fonte de $\mathrm{H}_{2}$, entretanto, esse processo necessita de muita energia elétrica, o que torna tal método de produção extremamente caro ${ }^{(20)}$.

Além deste obstáculo para a produção de $\mathrm{H}_{2}$, existe outro grave problema: se a energia elétrica a ser utilizada para a eletrólise da água, nesse processo de produção de $\mathrm{H}_{2}$, for fornecida por uma usina termoelétrica (energia elétrica gerada pelo calor, decorrente da queima de combustível sólido), esta também produzirá carbono, que da mesma maneira irá para a atmosfera na forma de $\mathrm{CO}_{2}$. Portanto, atualmente, apenas quem dispor de usinas hidroelétricas (energia elétrica gerada pelo deslocamento da água dos rios) e atômicas (que em condições normais não são poluentes), não produzirá $\mathrm{CO}_{2}{ }^{(20)}$.

É importante mencionar que mesmo com todo esse potencial de utilização do $\mathrm{H}_{2}$ como combustível ideal, ainda existem muitos obstáculos para serem superados, como, por exemplo, aperfeiçoamento e diminuição dos custos da produção de $\mathrm{H}_{2}$ utilizando o processo de eletrólise da água, além de investimentos na segurança ao uso do $\mathrm{H}_{2}$, em seu armazenamento, transporte e principalmente, desenvolver uma infra-estrutura específica para $0 \mathrm{H}_{2}$, em substituição à infra-estrutura atual dos combustíveis derivados do petróleo ${ }^{(16,20)}$.

\subsubsection{Outros combustíveis}

Como discutido anteriormente, existe a possibilidade de se utilizar diretamente ou indiretamente outros combustíveis, e não $\circ \mathrm{H}_{2}$ puro, em algumas tecnologias de CaCs. Entretanto, é importante destacar que a utilização de outros combustíveis não garante totalmente que a produção de energia elétrica será realizada sem a emissão de compostos poluentes ${ }^{(5,16,17,20,22)}$. 
A utilização do reformador em uma $\mathrm{CaC}$ objetiva extrair $\circ \mathrm{H}_{2}$ de um determinado combustível e eliminar substâncias nocivas ao meio ambiente e aos componentes da célula, entre eles, o eletrólito, o catalisador e os eletrodos ${ }^{(4,20)}$.

Alguns pesquisadores e autores costumam chamar o reformador como processador de combustível, mas normalmente entende-se por reformador a separação do $\mathrm{H}_{2}$ presente no combustível, mesmo contendo impurezas ${ }^{(4,20)}$.

Em algumas CaCs que operam em baixas temperaturas, como as PEMFCs e PAFCs ${ }^{(23)}$, e que precisam de $\mathrm{H}_{2}$ para uma operação adequada, há necessidade de um reformador externo de combustível (Figura 3.7), o que gera custos adicionais, além de um purificador que mantenha o teor de monóxido de carbono (CO) abaixo de 50 ppm. O ideal é estar abaixo de 10 ppm ${ }^{(19)}$.

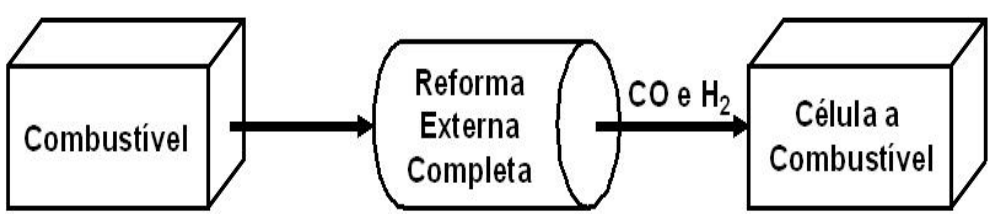

Figura 3.7 - Fluxograma ilustrativo de um processo de reforma externa ${ }^{(5)}$.

Existem algumas variações de CaCs que utilizam etanol ou metanol diretamente como combustível (Figura 3.8), como a CaC com uso de metanol direto (Direct Methanol Fuel Cell - DMFC) e a CaC com uso de etanol direto (Direct Ethanol Fuel Cell - DEFC) ${ }^{(4,16,17)}$.

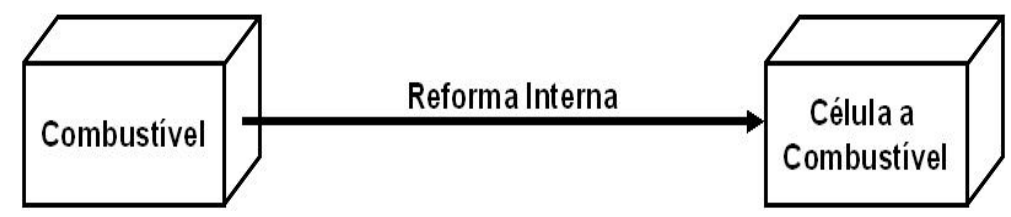

Figura 3.8 - Fluxograma ilustrativo de um processo de reforma interna ${ }^{(5)}$.

Nas CaCs que atuam em temperaturas mais elevadas (MCFC e SOFC), a alta temperatura de operação ajuda no processo de reforma do combustível, ativando mais facilmente as reações químicas, podendo utilizar um catalisador mais resistente e de menor custo, como o níquel (Ni), mesmo com a presença de substâncias nocivas, como os óxidos de nitrogênio (NOx) e o CO. Neste caso, pode-se utilizar o combustível diretamente na CaC (reforma interna), como apresentado na Figura 3.8, ou reformá-lo para eliminar as substâncias mais 
nocivas e depois utilizar o processado diretamente na célula (Figura 3.9), ou seja, uma pré-reforma externa seguida de interna ${ }^{(16,17)}$.

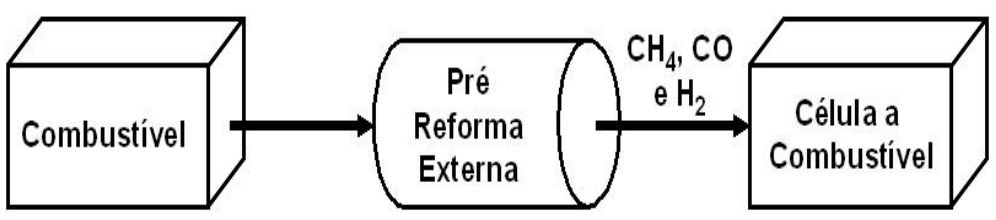

Figura 3.9 - Fluxograma ilustrativo de um processo de pré reforma externa ${ }^{(5)}$.

Apesar da a grande possibilidade de se utilizar o etanol, o metanol, o biogás e o gás natural para reforma externa ou interna em algumas CaCs, o ideal é utilizar $\mathrm{O} \mathrm{H}_{2}$ em seu estado mais puro, para conseguir maiores eficiências durante a operação, não degradar os componentes, diminuindo a vida útil da célula e principalmente garantir que não ocorra a emissão de compostos nocivos ao meio ambiente ${ }^{(5,22)}$.

\subsubsection{Princípio de funcionamento}

Agora que foi apresentado um pouco sobre a história e o conceito das CaCs e do $\mathrm{H}_{2}$ e alguns outros possíveis combustíveis, será discutido o princípio de funcionamento das CaCs. Entretanto, para um melhor entendimento, o $\mathrm{H}_{2}$ será utilizado como exemplo padrão de combustível.

As diferentes tecnologias de CaCs têm basicamente o mesmo princípio de funcionamento. São compostas por dois eletrodos porosos: o anodo e o catodo, cada um revestido ou não em um dos lados por uma camada de catalisador, e separados pelo eletrólito. O catalisador é um metal, normalmente platina $(\mathrm{Pt})$ ou $\mathrm{Ni}$, que acelera as reações químicas entre o $\mathrm{O}_{2}$ e $\circ \mathrm{H}_{2}{ }^{(16,17)}$.

Algumas CaCs utilizam eletrólitos líquidos e outras sólidos, mas somente os íons (positivos ou negativos) os atravessam, os elétrons não. $O$ anodo tem canais de fluxo que distribuem o $\mathrm{H}_{2}$ em sua superfície e no catalisador (se for o caso), além de remover a água produzida durante a reação ${ }^{(16,17)}$.

Dentro da $\mathrm{CaC}$ unitária, o gás $\mathrm{H}_{2}$ pressurizado é bombeado para $\mathrm{o}$ anodo, permitindo a permeabilização deste gás através do eletrodo negativo. Quando a molécula de $\mathrm{H}_{2}$ entra em contato com o catalisador, se separa em dois íons $\left(\mathrm{H}^{+}\right)$e dois elétrons $\left(\mathrm{e}^{-}\right)^{(\mathrm{A})}$. Os elétrons são conduzidos através do anodo, 
contornando o eletrólito até atingirem o circuito externo, onde, por exemplo, acendem uma lâmpada ou acionam um motor elétrico e retornam para o eletrodo positivo, o catodo ${ }^{(16,17)}$.

$$
\mathrm{H}_{2} \Rightarrow 2 \mathrm{H}^{+}+2 \mathrm{e}^{-}
$$

O gás oxigênio, puro ou extraído do ar, entra na $\mathrm{CaC}$ pelo catodo. $\mathrm{O}$ gás é disperso por todo o eletrodo positivo. Cada átomo de $\mathrm{O}_{2}$ atrai dois íons $\mathrm{H}^{+}$ através do eletrólito. Estes dois íons $\mathrm{H}^{+}$se combinam com $0 \mathrm{O}_{2}$ e mais dois elétrons provenientes do circuito externo, para formar a molécula de água ${ }^{(B)}$. Nesta reação, uma certa quantidade de calor é liberada ${ }^{(16,17)}$.

$$
\mathrm{O}_{2}+2 \mathrm{H}^{+}+2 \mathrm{e}^{-} \Rightarrow \mathrm{H}_{2} \mathrm{O}
$$

A Figura 3.10 apresenta uma ilustração do funcionamento de uma $\mathrm{CaC}$ unitária para eletrólitos condutores de íons positivos ou negativos ${ }^{(16)}$.

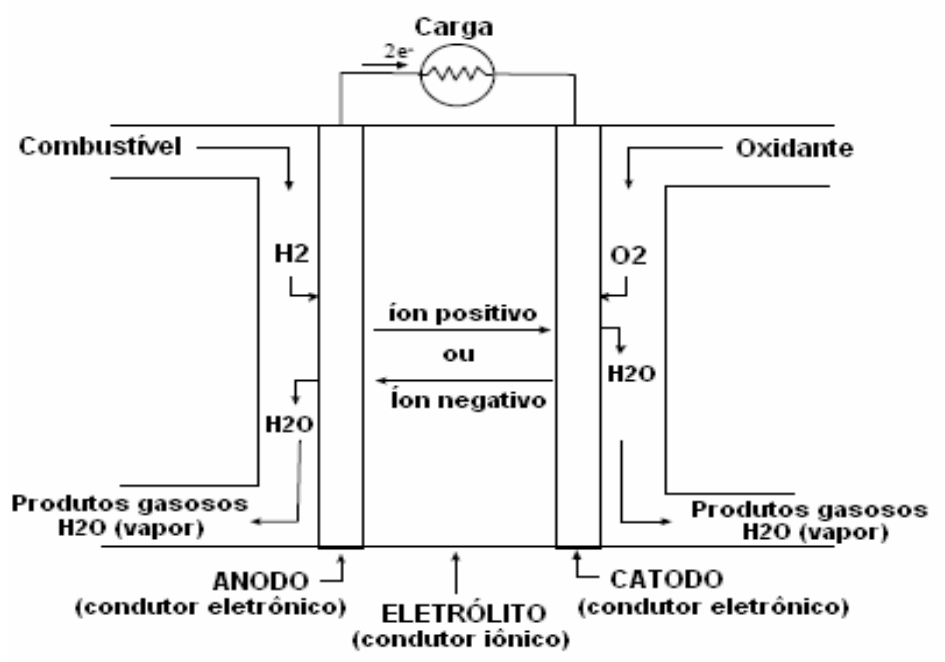

Figura 3.10 - Representação ilustrativa do funcionamento de uma CaC unitária ${ }^{(16)}$.

Após as reações, se tem vapor de água, que pode ser utilizado para aquecimento da água de um domicilio ou do próprio ambiente, ser integrado a uma micro-turbina (Figura 3.11a), onde o vapor de água produzido na CaC será aproveitado para produzir mais energia elétrica ou $\mathrm{H}_{2}$, através da eletrólise da água, utilizando por exemplo, um painel solar (Figura 3.11b) ${ }^{(16,17,24)}$. 


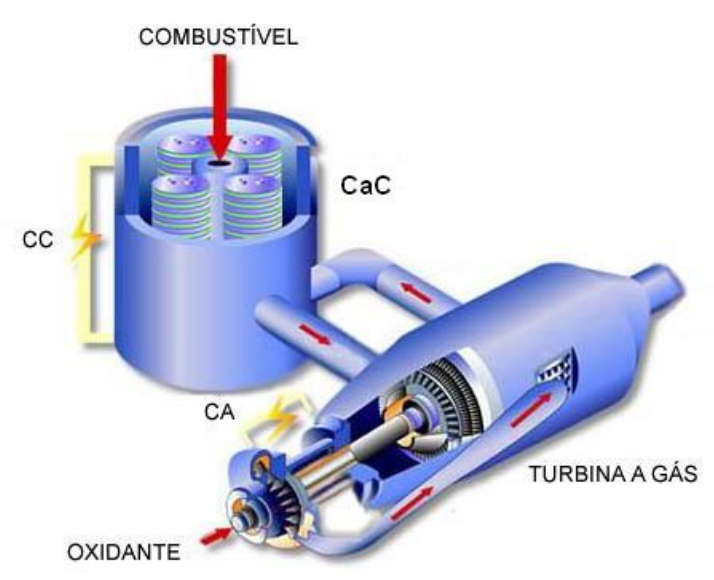

(a)

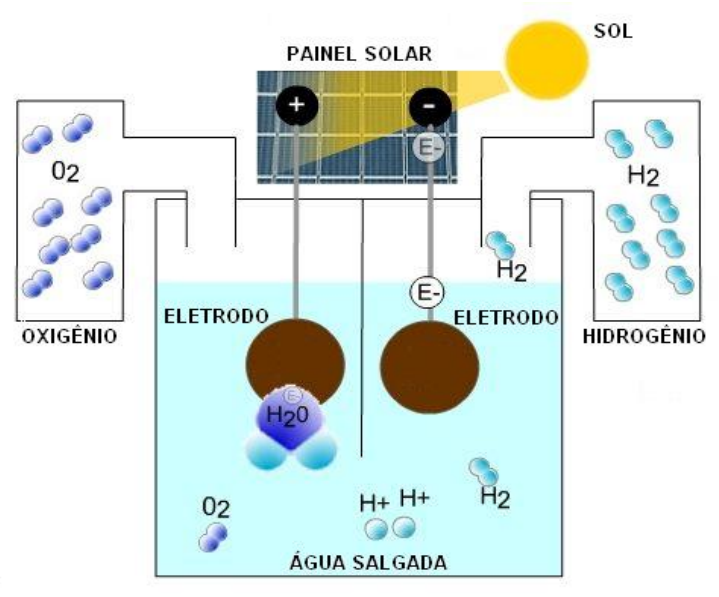

(b)

Figura 3.11 - CaC com micro-turbina a gás $(a)^{(24)}$ e eletrólise com painel solar (b) ${ }^{(19)}$.

\subsubsection{Principais características}

Devido às preocupações atuais com o aquecimento global e alteração de todo o clima e ecossistema em nosso planeta, a busca por fontes alternativas para geração de energia elétrica que tenham maior eficiência, menor impacto ambiental, que utilizem ciclos de vida renováveis e com menor custo operacional, tem recebido especial atenção, pois os modelos atuais, dependentes de combustíveis fósseis não atende a nenhuma destas solicitações ${ }^{(3,4)}$.

As CaCs possuem muitas características que são requisitadas e vantajosas, se comparadas com outros processos de produção de energia elétrica. A importância da tecnologia de $\mathrm{CaC}$ está na sua alta eficiência, principalmente quando se utiliza a co-geração, além da ausência de emissão de poluentes quando se utiliza o $\mathrm{H}_{2}$ em seu estado mais puro ${ }^{(16,17)}$.

As CaCs são dispositivos extremamente silenciosos e que operam com grande estabilidade, são fáceis de serem acionadas e funcionam continuamente sem nenhuma variação de tensão, podendo ainda serem construídas para aplicações grandes, médias, pequenas e portáteis ${ }^{(16,17)}$.

As CaCs oferecem ainda confiabilidade (ótima reprodutibilidade), economia, limpeza, características únicas de operação, flexibilidade de planejamento e potencial de desenvolvimento futuro ${ }^{(16,17)}$. 
Por ocorrerem reações eletroquímicas entre o combustível e o oxidante e por não necessitarem de nenhum processo de combustão interna, as CaCs não são limitadas pela termodinâmica do "Ciclo de Carnot" (Figura 3.12a), possuindo uma eficiência de sistema maior que os motores a combustão atuais até a uma temperatura de operação de aproximadamente $1200{ }^{\circ} \mathrm{C}(5,16,17)$.

As CaCs também possuem eficiência superior aos motores elétricos movidos a gasolina ou a óleo diesel e as turbinas movidas a gás ou a vapor (Figura 3.12b). Entretanto, a eficiência máxima teórica das CaCs é da ordem de aproximadamente $65 \%{ }^{(5,16,17)}$.

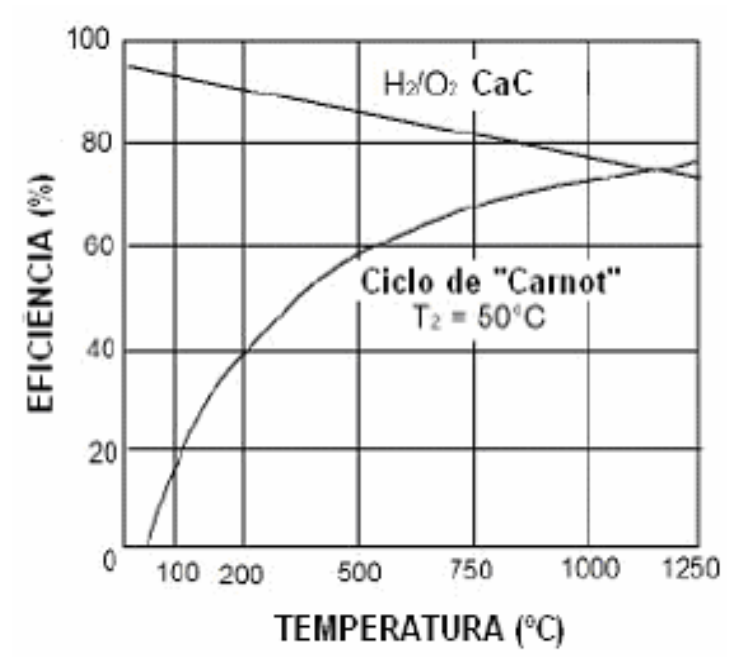

(a)

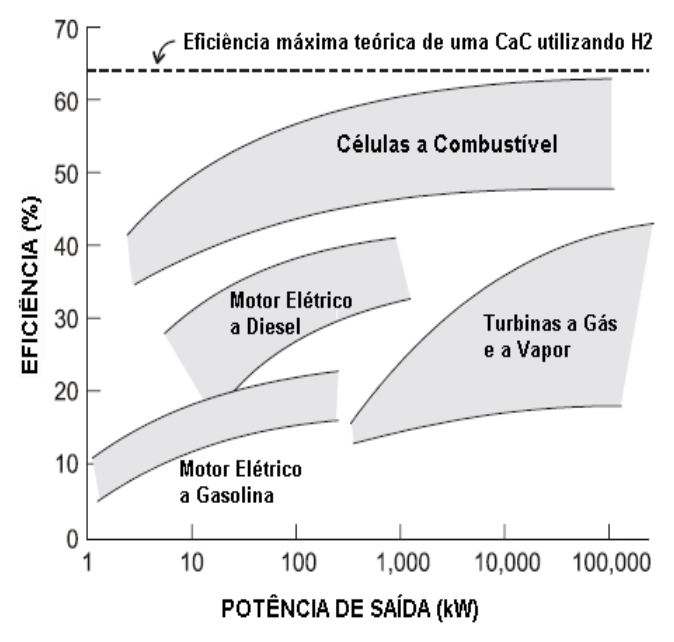

(b)

Figura 3.12 - Eficiência da CaC: Ciclo de Carnot (a), motores elétricos e turbinas (b) ${ }^{(5)}$.

Para conseguir maiores eficiências, é necessário utilizar a co-geração, cuja eficiência de sistema pode chegar a até 85 \% para algumas tecnologias de CaCs que operam em temperaturas elevadas ${ }^{(5,16)}$.

\subsubsection{Diferentes tecnologias}

Atualmente, existem uma grande variedade de CaCs, diferenciadas principalmente pelo eletrólito empregado. O eletrólito geralmente determina a temperatura de operação da célula, a qual varia bastante entre as diferentes tecnologias ${ }^{(4,16,17)}$. 
De todas as CaCs existentes atualmente, as principais são apresentadas na Tabela $3.1^{(4)}$.

Tabela 3.1 - Principais tecnologias de CaCs e suas características ${ }^{(4)}$.

\begin{tabular}{|c|c|c|c|c|c|c|c|}
\hline Tipo & Eletrólito & $\begin{array}{c}\text { Espécie } \\
\text { Transportada }\end{array}$ & $\begin{array}{c}\text { Temperatura } \\
\text { de Operação } \\
\left({ }^{\circ} \mathrm{C}\right)\end{array}$ & Vantagens & Desvantagens & Aplicações & $\begin{array}{c}\text { Eficiência } \\
(\%)\end{array}$ \\
\hline$A F C$ & $\begin{array}{c}\mathrm{KOH} \\
\text { concentrado }\end{array}$ & $\mathrm{OH}^{-}$ & $60-90$ & $\begin{array}{c}\text { Alta eficiência } \\
83 \%)\end{array}$ & $\begin{array}{l}\text { Sensível a } \mathrm{CO}_{2}, \\
\text { remoção da água, } \\
\text { Gases ultrapuros, } \\
\text { sem reforma. }\end{array}$ & $\begin{array}{c}\text { Espaçonaves, } \\
\text { Aplicações } \\
\text { militares }\end{array}$ & $>80$ \\
\hline PAFC & $\begin{array}{c}\text { Ácido } \\
\text { Fosfórico } \\
90-100 \% \\
\left(\mathrm{H}_{3} \mathrm{PO}_{4}\right)\end{array}$ & $\mathrm{H}_{3} \mathrm{O}^{+}$ & $160-200$ & $\begin{array}{c}\text { Maior } \\
\text { desenvolvimento } \\
\text { tecnológico }\end{array}$ & \begin{tabular}{|c} 
Vida útil limitada \\
pela corrosão, \\
Controle da \\
porosidade do \\
eletrodo e, \\
Sensibilidade a \\
CO $(>2 \%)$
\end{tabular} & $\begin{array}{c}\text { Unidades } \\
\text { estacionárias } \\
\text { (100kW a alguns } \\
\text { MW), Cogeração } \\
\text { eletricidade/calor }\end{array}$ & $40-50$ \\
\hline MCFC & $\begin{array}{l}\text { Misturas de } \\
\text { Carbonatos } \\
\text { fundidos } \\
\left(\mathrm{CO}_{3}{ }^{2-}\right)\end{array}$ & $\mathrm{CO}_{3}^{-2}$ & $650-700$ & $\begin{array}{c}\text { Tolerância a } \\
\text { CO/CO2 } \\
\text { Eletrodos à base } \\
\text { de Ni, Reforma } \\
\text { interna, alta } \\
\text { eficiência terórica }\end{array}$ & $\begin{array}{c}\text { Corrosão do } \\
\text { cátodo, Interface } \\
\text { trifásica de difícil } \\
\text { controle }\end{array}$ & $\begin{array}{c}\text { Unidades } \\
\text { estacionárias(100 } \\
\text { kW a } 1 \mathrm{MW}), \\
\text { Cogeração de } \\
\text { eletricidade/calor }\end{array}$ & $>60$ \\
\hline PEMFC & $\begin{array}{c}\text { Polímero } \\
\text { condutor de } \\
\text { protons } \\
\text { Nafion } \AA\end{array}$ & $\mathrm{H}^{+}$ & $80-90$ & $\begin{array}{c}\text { Alta densidade de } \\
\text { potência, } \\
\text { Operação } \\
\text { flexível, } \\
\text { Mobilidade } \\
\end{array}$ & $\begin{array}{c}\text { Custo da } \\
\text { membrana, } \\
\text { Contaminação do } \\
\text { catalisador com } \\
\text { CO }\end{array}$ & $\begin{array}{c}\text { Veículos, } \\
\text { Espaçonaves e } \\
\text { Unidades } \\
\text { estacionarias }\end{array}$ & $45-50$ \\
\hline SOFC & $\begin{array}{l}\text { Óxidos de } \\
\text { Céria e } \\
\text { Gadolínia } \\
\text { (ITSOFC) } \\
\text { Zircônia } \\
\text { estabilizada } \\
\text { (HTSOFC) }\end{array}$ & $\mathrm{O}^{-2}$ & $\begin{array}{c}500-800 \\
(\text { ITSOFC) } \\
\\
800-1000 \\
(\text { HTSOFC) }\end{array}$ & $\begin{array}{c}\text { Alta eficiência } \\
\text { (cinética } \\
\text { favorável). } \\
\text { Reforma interna }\end{array}$ & $\begin{array}{c}\text { Problemas de } \\
\text { materiais; } \\
\text { Expansão térmica }\end{array}$ & $\begin{array}{c}\text { Unidades } \\
\text { estacionárias } \\
\text { (10kW a 1 MW), } \\
\text { Cogeração de } \\
\text { eletricidade/calor. }\end{array}$ & $>60$ \\
\hline
\end{tabular}

Cada tecnologia requer materiais particulares para seus componentes, além de ter a sua aplicação direcionada para onde é mais favorável economicamente ${ }^{(4,5)}$. As siglas das diferentes tecnologias de CaCs apresentadas na tabela anterior significam ${ }^{(4)}$ :

- $\quad A F C$ (Alkaline Fuel Cell): célula a combustível alcalina;

- PAFC (Phosphoric Acid Fuel Cell): célula a combustível de ácido fosfórico;

- MCFC (Molten Carbonate Fuel Cell): célula a combustível de carbonato fundido;

- PEMFC (Proton Exchange Membrane Fuel Cell): célula a combustível com uso de membrana trocadora de prótons;

- SOFC (Solid Oxide Fuel Cell) célula a combustível de óxido sólido. 
A SOFC possui algumas variações de acordo com a sua configuração ou temperatura de operação ${ }^{(25)}$. Estas variações serão descritas no item 3.2 .5 (Principais Configurações) localizado no sub-capítulo 3.2 (Células a Combustível de Óxido Sólido).

Existem algumas tecnologias de $\mathrm{CaCs}$ que utilizam a base das tecnologias anteriores. Entre elas podemos destacar ${ }^{(4)}$ :

- DMFC (Direct Metanol Fuel Cell): célula a combustível com uso de metanol direto;

- DEFC (Direct Etanol Fuel Cell): célula a combustível com uso de etanol direto.

Por fim, outras tecnologias que também estão atualmente em estudos e pesquisas ${ }^{(21)}$ :

- RFC (Reversible Fuel Cell): célula a combustível reversível;

- ZAFC (Zinc-Air Fuel Cell): célula a combustível zinco-ar;

- PCFC (Protonic Ceramic Fuel Cell): célula a combustível de cerâmica protônica;

- DBFC (Direct Borohydride Fuel Cell) - célula a combustível com uso de borohidreto direto;

- EGFC (Electro-Galvanic Fuel Cell) - célula a combustível eletrogalvânica;

- FAFC (Formic Acid Fuel Cell) - célula a combustível de ácido fórmico;

- MFC (Microbial Fuel Cell) - célula a combustível microbiológica;

- MHFC (Metal Hydride Fuel Cell) - célula a combustível de hidreto metálico;

- PEC (Photoelectrochemical Cell) - Célula fotoelétroquímica.

As diferentes tecnologias de CaCs podem ser classificadas também de acordo com a sua temperatura de operação, como por exemplo, as células de alta temperatura de operação (MCFC e SOFC) e as de baixa temperatura de operação (AFC, PAFC e PEMFC) ${ }^{(16,17)}$. 
Entretanto, existe um grande esforço no sentido de se reduzir a temperatura de operação das chamadas $\mathrm{CaCs}$ de alta temperatura, de forma a minimizar os problemas relacionados à estabilidade e custo de materiais ${ }^{(26)}$.

A CaC mais pesquisada para aplicações em automóveis é a PEMFC, por apresentar características como resposta mais rápida na solicitação de potência e início de operação, além da temperatura ser relativamente baixa, em torno de 80 a $100^{\circ} \mathrm{C}(21,27)$.

Para aplicações estacionárias em indústrias e hospitais, por exemplo, as CaCs mais pesquisadas são a MCFC e a SOFC, pois operam em altas temperaturas, podendo ser aproveitado o calor de exaustão para aquecimento de água e para gerar mais energia elétrica através do processo de co-geração ${ }^{(21,27)}$.

Em residências, as CaCs mais pesquisadas são a PAFC, a PEMFC e a SOFC. Na área de equipamentos portáteis, principalmente celulares e laptops, as mais pesquisadas são a $P E M F C$ e a $D M F C^{(5,21)}$.

\subsubsection{Principais componentes}

Um sistema de CaC é composto de diversos componentes, muitos deles feitos de materiais complexos e de alto custo. Um pesquisador sozinho não consegue desenvolver ou aperfeiçoar uma $\mathrm{CaC}$, pois envolve conceitos em diversas áreas, sendo necessário ter especialistas, tais como físicos, químicos, engenheiros (elétricos, mecânicos, químicos e de materiais), técnicos em química, técnicos em oficina, entre outros ${ }^{(21)}$.

De todos os componentes que fazem parte de uma $\mathrm{CaC}$ unitária, os principais são: os eletrodos (anodo e catodo), o eletrólito, o catalisador e o interconector ou placa bipolar (quando se utiliza a configuração planar) ${ }^{(5,16,17)}$.

O eletrodo é um componente que está entre o eletrólito e o interconector ${ }^{(16,17)}$. Um bom eletrodo deve permitir a difusão dos gases $\mathrm{H}_{2}$ e $\mathrm{O}_{2}$, proporcionar uma reação na superfície onde possam entrar em contato com o eletrólito, ter condutividade aos elétrons livres que fluem do anodo para o catodo ou vice-versa, e poder ser construído com materiais compatíveis para uma determinada $\mathrm{CaC}^{(5,28)}$. O material do eletrodo é geralmente feito de cerâmica, extremamente poroso e muito fino, para maximizar o transporte dos gases e da água dentro da célula ${ }^{(28)}$. 
Juntamente com os eletrodos, o eletrólito é o coração de uma $\mathrm{CaC}$ e possui a propriedade de deixar passar íons positivos ou negativos. A temperatura de operação das células está ligada ao tipo de eletrólito utilizado, cada uma com vantagens e desvantagens, dependendo da aplicação e dos combustíveis que podem ser utilizados ${ }^{(28)}$. O eletrólito alcalino, por exemplo, precisa que os gases $\mathrm{O}_{2}$ e $\mathrm{H}_{2}$ estejam puros, sem a presença de outros compostos, para que não ocorra o processo de degradação dos componentes no interior da célula ${ }^{(5,16,17)}$.

O catalisador, em algumas CaCs, é responsável pela quebra da molécula de $\mathrm{H}_{2}$ em $\mathrm{H}^{+}$(íons positivos) e elétrons (íons negativos). $\mathrm{O}$ catalisador é adicionado à superfície de cada eletrodo, fazendo o contato com o eletrólito, de forma a aumentar a taxa das reações químicas e é o principal responsável pela ocorrência dessas reações. A platina geralmente é utilizada como catalisador, possuindo alta estabilidade e excelente condutividade elétrica. O problema é que a Pt é muito cara e com tendências de aumentar o seu custo, tendo inclusive uma participação significativa no orçamento final de uma $\mathrm{CaC}$. Principalmente por este motivo, os pesquisadores procuram minimizar a quantidade de Pt utilizada sem perder a eficiência do processo. Geralmente a Pt é utilizada em CaCs que operam em baixas temperaturas, entre 80 e $200^{\circ} \mathrm{C}$, como a PEMFC ou a PAFC. Nas CaCs que operam em temperaturas mais elevadas, entre 300 e $1000{ }^{\circ} \mathrm{C}$, não há necessidade de um excelente catalisador, pois a alta temperatura já ativa um grande número de reações químicas. Desta forma, o Ni pode ser utilizado como um catalisador bem eficiente e de baixo custo ${ }^{(5,16,17)}$.

O interconector é utilizado para promover a conexão elétrica entre o anodo de uma célula unitária e o catodo da célula adjacente ou vice-versa, além de atuar como uma barreira física para os gases envolvidos (se o oxidante e o combustível forem gasosos), evitando, desta forma, a mistura do combustível presente no anodo, com o oxidante presente no catodo. O material é geralmente cerâmico, metal ou um cermet (compósito cerâmico-metal) e deve ser o mais denso possível, evitando a passagem dos gases reagentes para não ocasionar um curto-circuito na célula em operação ${ }^{(5,29)}$. 


\subsubsection{Aplicações}

As CaCs têm o potencial e a vantagem de poderem ser utilizadas em uma grande variedade de aplicações, desde automóveis e equipamentos portáteis, até os setores aéreo, naval, militar e espacial, incluindo a geração de energia estacionária de pequeno, médio e grande porte ${ }^{(16,17)}$.

A tecnologia de $\mathrm{CaC}$ começou a ganhar impulso a partir dos programas espaciais norte-americanos nas décadas de 1960 e 1970, estendendo-se até os dias atuais. As células servem para fornecer energia para todos os equipamentos eletro eletrônicos de bordo, além de gerar água pura para os tripulantes e para o resfriamento dos sistemas da espaçonave ${ }^{(16-18)}$.

O segmento de aplicação portátil será o primeiro a atingir o mercado comercial em massa. Atualmente, estima-se que mais de cinco mil sistemas de $\mathrm{CaC}$ tenham sido construídos e estejam em operação no mundo inteiro, principalmente nos Estados Unidos, Japão, Alemanha e Canadá ${ }^{(4,21)}$.

Outro setor que recebe muitos investimento para CaCs é a aplicação militar. A eficiência, versatilidade, maior período de operação e ausência de ruídos, faz das CaCs extremamente apropriadas para as necessidades de energia elétrica dos serviços militares. As CaCs podem fornecer energia para a maioria dos equipamentos militares, desde equipamentos de mão, utilizados em campo, até transporte terrestre, marítimo e aéreo ${ }^{(5,22)}$.

No setor de transporte urbano, as atenções estão voltadas principalmente para automóveis e ônibus. Já foram investidos mais de dois bilhões de dólares neste segmento pelas grandes indústrias, prevendo-se a produção em massa para a nova geração de veículos, movidos a hidrogênio, a partir da próxima década. A General Motors espera produzir até o ano de 2020, um milhão de automóveis contendo $\mathrm{CaC}$. Dentro de aproximadamente sete anos, será um mercado de cerca de 10 bilhões de dólares anuais ${ }^{(21)}$.

No Brasil, $60 \%$ das instituições de pesquisa e investidores de projetos envolvendo tecnologias de CaCs estão direcionados para aplicações residenciais e estacionárias de médio e grande porte ${ }^{(20)}$.

Estamos começando a viver a era do hidrogênio, onde os primeiros passos estão sendo dados para que a atual economia baseada no petróleo se transforme na futura economia baseada no hidrogênio ${ }^{(20)}$. 


\subsubsection{Benefícios}

As CaCs são uma forma de geração de energia ecologicamente correta e podem trazer benefícios ambientais, sociais e econômicos ${ }^{(16,17,20)}$.

A tecnologia de $\mathrm{CaC}$ tem sido reconhecida como uma forma limpa de produzir eletricidade com alta eficiência energética em diversas aplicações, desde a portátil até em geração distribuída. Não importando a sua aplicação, elas oferecem um grande número de benefícios para usuários individuais, companhias de energia elétrica e para a sociedade em geral ${ }^{(16,17,20)}$.

Enquanto os benefícios ambientais da geração distribuída ainda são discutidos, os das CaCs têm estimulado o seu uso em locais com alta concentração de poluentes, para ajudar a minimizar os problemas de poluição atmosférica e melhorar as condições sociais ${ }^{(16,17,20)}$.

Pelo fato de produzirem energia sem combustão, as CaCs são, em média, até $25 \%$ mais eficientes que os motores a combustão interna, reduzindo a emissão de poluentes e também de $\mathrm{CO}_{2}$ na atmosfera ${ }^{(4,16,17)}$.

Mesmo quando $\circ \mathrm{H}_{2}$ é obtido a partir de fontes fósseis, como os derivados do petróleo e o gás natural, a emissão de $\mathrm{CO}_{2}$ cai de $25 \%$ a $50 \%$, e a fumaça produzida, quando comparada com equipamentos tradicionais como os geradores a óleo diesel, diminui em até $99 \%{ }^{(20)}$.

$\mathrm{Na}$ busca de um melhor aproveitamento dos benefícios proporcionados pelas CaCs, a utilização das fontes de energia renováveis são um ponto crucial para aproveitar integralmente as vantagens das células, pois durante 0 crescimento destas, como a cana-de-açúcar, ocorre o seqüestro de carbono presente na atmosfera, além da liberação de maior quantidade de oxigênio ${ }^{(20)}$.

Como as previsões das reservas de petróleo estão estimadas para mais 40 ou 50 anos ${ }^{(21)}$, uma forma de se aumentar este tempo é utilizar equipamentos eficientes como as $\mathrm{CaCs}$, que são capazes de produzir a mesma quantidade de energia utilizando o mínimo dos derivados do petróleo ${ }^{(16,17)}$.

O Departamento de Energia dos Estados Unidos da América (EUA) estima que se somente $10 \%$ dos automóveis norte-americanos utilizassem $\mathrm{CaCs}$, a emissão regular de poluentes diminuiria em 1 milhão de toneladas por ano, além de diminuir em 60 milhões de toneladas a quantidade de $\mathrm{CO}_{2}$ emitida para a atmosfera, reduzindo a importação em oitocentos mil barris de petróleo por ano 
(cerca de $13 \%$ do total de importação de petróleo dos EUA) ${ }^{(30)}$. Dentre todos os benefícios ambientais, os principais são ${ }^{(5,16,17)}$ :

- Minimiza nossa dependência em combustíveis derivados do petróleo para a produção de energia elétrica;

- Emite menos gases causadores do efeito estufa;

- Maior eficiência na geração da energia e no consumo da fonte de energia;

- Redução de pilhas e baterias nos aterros sanitários.

As CaCs fornecem energia limpa numa grande variedade de aplicações e oferecem um número considerável de benefícios aos seus usuários, desde companhias de eletricidade até a sociedade como um todo, possibilitando maior confiabilidade em energia com a mínima emissão de poluentes na atmosfera. Assim, juntamente com outras tecnologias de geração de energia renovável, como as células fotovoltaicas e as usinas eólicas, as CaCs possuem benefícios sociais extremamente consideráveis ${ }^{(4,16,17)}$.

Uma grande quantidade de CaCs instaladas em determinada região, por exemplo, gera maior segurança no uso da energia, melhora a qualidade do ar e do meio-ambiente. Os consumidores de energia elétrica, e também as próprias companhias de energia podem aproveitar os benefícios através da melhora na confiabilidade do sistema elétrico, diminuindo os problemas decorrentes das longas e atuais linhas de transmissão ${ }^{(20)}$.

A comercialização em massa das CaCs representa uma excelente oportunidade de desenvolvimento econômico para o país e para as regiões que utilizarem esta tecnologia, pois poderá criar indústrias de desenvolvimento, fornecedores, comerciantes e companhias de manutenção ${ }^{(20)}$. Os principais benefícios sociais que as CaCs podem oferecer, são ${ }^{(16,17,20)}$ :

- Redução da poluição atmosférica e melhora na saúde respiratória;

- Redução na emissão de gases causadores do efeito estufa;

- Benefícios da geração distribuída;

- Segurança em energia elétrica. 
À medida que as CaCs substituírem equipamentos velhos e pouco eficientes, alguns benefícios podem ser obtidos, tais como ${ }^{(20)}$ :

- Redução de pilhas e baterias nos aterros sanitários;

- Redução de prejuízos na agricultura através da redução da chuva ácida e dos níveis de concentrações de ozônio próximo à superfície;

- Redução da poluição sonora, pois as CaCs não possuem partes móveis e operam silenciosamente. Assim, a poluição sonora causada pelo trânsito irá diminuir e o conforto das pessoas que trabalham em locais onde normalmente se utiliza motores a óleo diesel (extremamente barulhentos) irá aumentar;

- Redução da contaminação do lençol freático a partir dos automóveis. Hoje, praticamente todos os veículos utilizam óleo para lubrificação dos motores, ocorrendo muitos vazamentos que contaminam a superfície e provocam acidentes nas estradas. As CaCs não utilizam óleo para a manutenção;

- Redução da emissão de partículas na atmosfera, como cinzas da fumaça.

Embora seja esperado um crescimento significativo do mercado das CaCs em todo o mundo, o pequeno mercado existente atualmente irá resultar no crescimento de novas indústrias ${ }^{(21)}$

Em 2001, o mercado de CaCs nos EUA era de 218 milhões de dólares. Para este ano, o crescimento do mercado será de mais de 2,5 bilhões de dólares, segundo a BCC (Business Communications Company), empresa que estudou e analisou o mercado norte-americano de CaCs. Em 2009, serão mais de 7 bilhões de dólares e estima-se que em 2025, caso o crescimento de $25 \%$ ao ano se mantenha, o mercado será de mais de 85 bilhões de dólares ${ }^{(31)}$.

Assim, o Brasil, que tem um potencial enorme para desenvolver esta tecnologia, deve investir pesado e buscar a parceria público-privada. Como resultado, muitas oportunidades para desenvolvimento econômico poderão ser criadas. Para dar suporte aos fabricantes e também a indústria de desenvolvimento tecnológico, novos fornecedores, comerciantes e empresas de manutenção serão necessários ${ }^{(20)}$. 
Esta tecnologia, diferentemente da indústria de desenvolvimento de eletro eletrônicos e processadores de computador, por exemplo, pode fazer do Brasil uma possível referência mundial e grande candidato a competir no mercado externo, pois temos uma grande experiência e base financeira no setor de energia elétrica, agrícola e principalmente de etanol ${ }^{(21)}$.

Devido às suas disponibilidades e por serem menos poluentes, o gás natural e o propano deverão ser os combustíveis primários para as CaCs. No Brasil e nos EUA, o potencial do etanol pode ser aproveitado, tendo a vantagem de criar muitos empregos no campo, além de ser uma fonte renovável de energia. No início, até a gasolina poderá ser utilizada, enquanto todo o planeta estiver preparando a infra-estrutura para o $\mathrm{H}_{2}{ }^{(20,21)}$.

\subsubsection{Desafios atuais}

Alguns especialistas acreditam que o futuro baseado em $\mathrm{CaC}$ acontecerá dentro de pouco mais de uma década, mas muitos desafios devem ser superados. Diversos programas de cooperação pública-privada serão necessários para demonstrar os benefícios das $\mathrm{CaCs}$ e alcançar a comercialização em massa. Muitas barreiras técnicas e econômicas devem ser analisadas para que as CaCs sejam utilizadas em diversas aplicações ${ }^{(32-35)}$.

A principal barreira para que as CaCs atinjam o mercado mundial é o seu custo, seja qual for a tecnologia ou aplicação. As reduções nos custos devem ocorrer desde as matérias-primas até a manufatura da célula e seus componentes. A quantidade a ser reduzida no custo final depende muito da tecnologia e da sua aplicação ${ }^{(32,33)}$.

Para conseguir uma redução nas matérias-primas, deve haver uma combinação de materiais alternativos com custos menores, preço por quantidade, e uma redução na quantidade de materiais de alto custo. O custo de manufatura pode ser reduzido parcialmente através de práticas conhecidas ${ }^{(33,36)}$.

Entretanto, será necessária a introdução de uma nova tecnologia de fabricação ou propostas que produzam processos de manufatura mais simples. Pelo fato dos tamanhos das células e componentes não serem padronizados, os custos são relativamente altos ${ }^{(36)}$. 
Particularmente na aplicação em transportes, o custo é um fator determinante. Com a tecnologia atual de CaCs em veículos, e para uma quantidade de quinhentos mil unidades por ano, resultaria em um custo entre US\$ $195,00 / \mathrm{kW}$ a US\$ $325,00 / \mathrm{kW}^{(21)}$. Este custo está relacionado à eficiência e à desempenho obtido com CaCs fabricadas até o início de 2005 e, considerando que foram produzidas em alta escala. O custo real para atingir um desempenho equivalente, com base no tamanho e no peso de um veículo convencional, é maior, pois a tecnologia atual não alcança estes requisitos. O custo atual de motores a combustão está entre US\$25,00/kW a US\$35,00/kW ${ }^{(32,33)}$.

Nos EUA, a organização The Solid State Energy Conversion

Alliance (SECA), uma aliança entre o governo, indústria e comunidade científica, que promove o desenvolvimento de SOFCs, estabeleceu como objetivo um custo de aproximadamente US\$400,00/kW para células de $5 \mathrm{~kW}$ de potência utilizando a configuração planar para uma produção em massa de 100 mil unidades por ano. Este objetivo também representa uma redução significativa, se comparada aos custos dos sistemas atuais. Algumas empresas de desenvolvimento estão operando células por mais de 40 mil horas e também outras de $2 \mathrm{~kW}$ por mais de mil horas. O desafio tecnológico de alcançar 40 mil horas de vida útil a um custo de US\$ 400,00/kW leva a um avanço de desenvolvimento significativo ${ }^{(37)}$.

O custo para aplicações portáteis e de standby (emergência) são mais tolerantes do que para as aplicações estacionárias e móveis. Obviamente o custo para $\mathrm{CaCs}$, com finalidade de standby, deve ser similar àqueles destinados a geração distribuída, mas a vida útil do equipamento não será tão importante. Para equipamentos portáteis, como telefones celulares, o custo de produção em alta escala será alcançado com maior facilidade, mas a vida útil ainda será curta ${ }^{(21)}$.

O segundo problema tecnológico a ser superado é a durabilidade das CaCs. O mercado requer altíssima confiabilidade e longa vida útil para que haja competição satisfatória com as tecnologias de geração de energia existentes. Por exemplo, a maior parte do mercado estacionário (geradores, motores e turbinas a diesel e a gás) exige vida útil de mais de 40 mil horas e, em sistemas de transporte, de mais de 5 mil horas (170 mil quilômetros), superando questões climáticas severas, suportando condições de acionamento e desligamento sucessivos, além de condições cíclicas transientes ${ }^{(5,16,17)}$. 
Ainda não se pode dizer que as características de confiabilidade e durabilidade são satisfatórias, embora as PAFCs de $200 \mathrm{~kW}$ cada (Figura 3.13) e em operação em várias regiões no mundo, inclusive no Alasca, tenham demonstrado uma confiabilidade e durabilidade muito satisfatórias ${ }^{(20,21)}$.

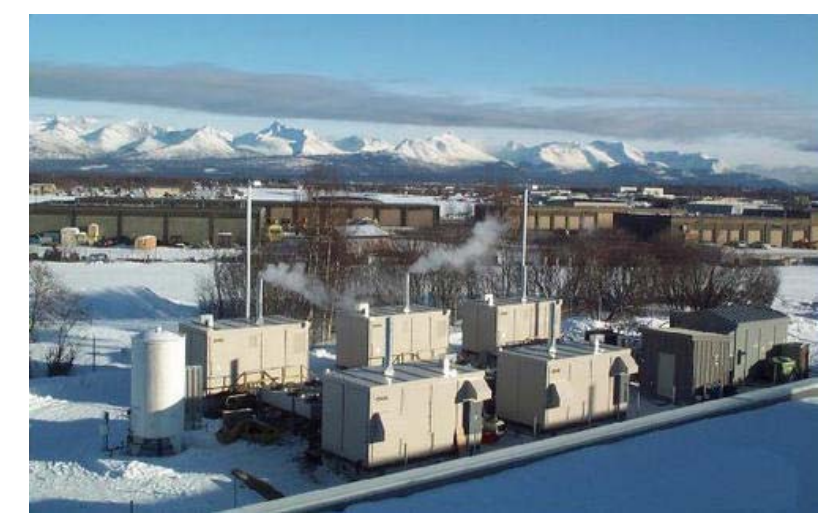

Figura 3.13 - Estação de PAFCs instalada no Alasca ${ }^{(38)}$.

As CaCs de baixa temperatura de operação (PEMFC e PAFC) necessitam de Pt como catalisador para alcançar a densidade de potência requerida. A utilização de $\mathrm{Pt}$ como catalisador em baixas temperaturas faz com que ela seja suscetível à contaminação do $\mathrm{CO}$ na região de alimentação do combustível. Os compostos sulfurosos também são um problema de corrosão cumulativa e permanente. Assim, os sistemas de alimentação de combustível nestas células, após a reforma do combustível, devem ser altamente limpos antes que sejam realmente utilizados ${ }^{(16,17,23)}$.

A utilização de elevada temperatura de operação alivia a situação, mas não a elimina. As MCFCs e as SOFCs não são sensíveis ao $\mathrm{CO}$, mas são afetadas pelos compostos sulfurosos. O fato de operarem em altas temperaturas leva a vantagens e desvantagens. Uma vantagem é a reforma interna do combustível na própria célula, não necessitando de um reformador externo e, com isso, diminuindo custos. Porém, os componentes devem resistir às altas temperaturas, pois podem sofrer degradação, entre outros problemas ${ }^{(16,17,35)}$.

O desenvolvimento de componentes a baixo custo e de alto desempenho, é um fator crítico e importante para o alcance de um sistema global a custo viável e boa eficiência para todos os tipos de CaCs e suas aplicações. Além disso, é necessária uma alta eficiência para ocorrer uma melhora nas 
dimensões (volume e peso) das células. Para aplicações móveis na área de transporte, o peso e o tamanho são muitos importantes, pois afetam diretamente a autonomia e o espaço interno para carga e passageiros ${ }^{(16,17,20)}$.

Um dos maiores desafios na área da tecnologia PEMFC é a criação de uma membrana que opere em temperaturas maiores que as atuais (em torno de 80 a $100^{\circ} \mathrm{C}$ ). Uma temperatura maior permitiria a utilização do calor de exaustão para co-geração ou um processo de aquecimento para reformar o combustível e extrair $\mathrm{O}_{2}{ }^{(10,23)}$.

\subsubsection{3. Áreas que necessitam de mais pesquisa}

Todos os sistemas de CaCs, independente da tecnologia, precisam de mais desenvolvimento e integração do balanço dos componentes do sistema, tais como trocadores de calor, compressores, sensores e controladores. A falta de atenção nestes componentes é comum, o que limita a confiabilidade e a durabilidade do sistema como um todo ${ }^{(21)}$.

O gerenciamento térmico e da água são de grande importância para as PEMFCs, e necessitam de uma umidificação do ar e do combustível para prevenir o processo de degradação da membrana (eletrólito) e evitar prejudicar a sua performance. Um fator complicado é a integração térmica entre a célula e o reformador de combustível, pois o calor rejeitado da célula e a manutenção do balanço da água se tornam críticas e de difícil operação ${ }^{(20,36)}$.

O hidrogênio ainda requer muitos desafios, como produção em quantidade abundante a custo baixo e de maneira ecologicamente limpa. A produção a partir de fontes de energia fósseis é relativamente cara se comparada aos combustíveis alternativos. Como a maior parte do hidrogênio é produzido a partir de hidrocarbonetos, o custo por unidade de energia gerada pelo hidrogênio é maior que o custo da mesma unidade de energia do próprio hidrocarboneto. Termodinamicamente sempre será assim, mas em relação ao uso eficiente de energia ( $\mathrm{CaC}$ versus motor a combustão), os custos podem ser comparados ${ }^{(4,20)}$.

Novos métodos para a produção de $\mathrm{H}_{2}$ a partir de fontes renováveis de energia precisam de desenvolvimento. No Brasil, os principais desafios estão nos grandes reservatórios das hidroelétricas brasileiras, como Itaipu, e no álcool da cana-de-açúcar. As usinas solares, eólicas e geotérmicas podem produzir $\mathrm{H}_{2}$ pelo 
processo de eletrólise, mas a biomassa pode produzir $\mathrm{H}_{2}$ diretamente e com um custo muito mais baixo ${ }^{(21)}$.

Outros métodos avançados para produção de $\mathrm{H}_{2}$ a partir de fonte de energia renovável e sustentável, sem gerar $\mathrm{CO}_{2}$, ainda estão em desenvolvimento. Processos como a quebra da molécula de água através de atividades termoquímicas, eletrólise fotoeletroquímica e métodos biológicos (a partir de algas e bactérias) precisam de tempo e investimentos para atingir nível comercial. Algumas tecnologias renováveis, como a solar, eólica e geotérmica, precisam também de mais desenvolvimento para que possam produzir $\mathrm{H}_{2}$ a um custo mais competitivo ${ }^{(33,36)}$.

\subsubsection{Pesquisa e Desenvolvimento no Brasil}

No Brasil, país com enorme potencial energético em várias fontes de energia, com destaque para a energia hidráulica, a pesquisa em CaCs está caminhando através da iniciativa de algumas empresas, institutos de pesquisa e universidades apoiadas financeiramente pelas concessionárias de energia e pelo governo brasileiro ${ }^{(21,39)}$.

O projeto de uma $\mathrm{CaC}$ envolve estudos sobre quais combustíveis são mais apropriados para o mercado brasileiro, quais as melhores formas de armazenar e reformar estes combustíveis, qual tecnologia deve ser utilizada para determinada aplicação e como melhorar a durabilidade e a eficiência ${ }^{(21)}$.

Os principais estudos de pesquisa estão voltados para o setor automobilístico e de geração de energia estacionária, principalmente residencial e comercial. Não há ainda no Brasil empresas pesquisando aplicações de CaC para equipamentos portáteis. Apesar do desinteresse nacional, esta aplicação será a de maior proximidade com o público mundial nos próximos anos ${ }^{(39)}$.

$\mathrm{Na}$ área de combustíveis se tem dado atenção especial ao álcool da cana-de-açúcar como fonte de $\mathrm{H}_{2}$, assim como o tipo de armazenamento de $\mathrm{H}_{2}$ em carros, desde comprimi-lo até estocá-lo em metais com a propriedade de absorvê-lo. Por meio do plano de massificação criado pela Petrobrás, o gás natural também deverá despertar a atenção dos pesquisadores ${ }^{(4,20,39)}$.

O governo brasileiro tem demonstrado interesse em apoiar o desenvolvimento das CaCs através do lançamento oficial, em novembro de 2002, 
do atual $\mathrm{PROH} 2$, uma iniciativa do MCT coordenado pelo CGEE do próprio ministério. O programa tem como principal objetivo incentivar um conjunto articulado de projetos de pesquisa, desenvolvimento e informações em diferentes áreas de atuação para a tecnologia nacional de $\mathrm{CaC}$ e $\mathrm{H}_{2}{ }^{(14,20)}$.

Empresas como a Clamper, a Unitech e a CEMIG estão investindo em projetos de $\mathrm{CaC}$ para o mercado residencial, utilizando etanol ou $\mathrm{H}_{2}$ como combustíveis. No Paraná, a Copel (Companhia Paranaense de Energia), em parceria com o Lactec (Instituto de Tecnologia para o Desenvolvimento), desenvolve pesquisas com CaC da UTC FCs, que utiliza tecnologia $A F C{ }^{(21)}$.

$\mathrm{Na}$ UFPR, há um estudo de otimização de PEMFC, financiado pela ANP, e estudos de obtenção de $\mathrm{H}_{2}$ pela eletrólise da água. Também se estuda uma modelagem teórica do funcionamento de todas as $\mathrm{CaCs}^{(21)}$.

Em São Paulo, a Electrocell em parceria com a Eletropaulo e a FAPESP, está desenvolvendo PEMFCs através do CIETEC (Centro Incubador de Empresas Tecnológicas), localizado no IPEN, no campus da USP (21).

No Rio de Janeiro, o LABH2 (Laboratório de Hidrogênio) da COOPE (Coordenação de Programas de Pós-Graduação em Engenharia) da UFRJ está desenvolvendo, juntamente com a Renault, uma das mais promissoras linhas de pesquisa em curso no mundo: $\mathrm{O}$ armazenamento de átomos de $\mathrm{H}_{2}$ inseridos dentro da estrutura atômica de um metal ${ }^{(21)}$.

A UNICAMP está desenvolvendo um protótipo de reformador de etanol para a produção de $\mathrm{H}_{2}$ e capaz de gerar $300 \mathrm{~W}$ em corrente alternada. Além deste, também estuda outros dois projetos de geração de energia elétrica com CaCs. O primeiro, realizado em parceria com a FAPESP, terá $1 \mathrm{~kW}$ de capacidade. O outro, desenvolvido com a Petrobrás, terá $5 \mathrm{~kW}{ }^{(21)}$.

Novamente em São Paulo, a EMTU (Empresa Metropolitana de Transportes Urbanos de São Paulo) desenvolve o projeto de ônibus com $\mathrm{CaC}$ utilizando $\mathrm{H}_{2}$ como combustível. Com o apoio do PNDU (Programa das Nações Unidas para o Desenvolvimento), o projeto consiste na aquisição, operação e manutenção de oito ônibus com $\mathrm{CaC}$ movidos a $\mathrm{H}_{2}$ e uma estação de produção e abastecimento, além de acompanhamento e verificação do desempenho desses veículos durante toda a operação ${ }^{(4,21)}$. 
Para prestar apoio e trocar informações sobre estudos sobre o $\mathrm{H}_{2}$, foi criado o Centro Nacional de Referência em Energia do Hidrogênio pelo MCT, Governo de São Paulo, UNICAMP, USP, CEMIG e Instituto Vitae Civilis ${ }^{(40)}$.

Em Florianópolis (SC), o INEP (Instituto Nacional de Eletrônica de Potência), com sede na UFSC (Universidade Federal de Santa Catarina), juntamente com PHB Eletrônica de São Paulo, está se especializando no controle e monitoramento de uma $\mathrm{CaC}$ de $3 \mathrm{~kW}^{(21)}$.

A UNIVALI (Universidade do Vale do Itajaí), também em Santa Catarina, em parceria com a CELESC (Concessionária de Energia de Santa Catarina), está utilizando $\mathrm{o}_{2}$ no desenvolvimento de uma $\mathrm{CaC}$ e pretende trabalhar também com o etanol como um combustível ${ }^{(21)}$.

O TECPAR (Instituto de Tecnologia do Paraná) está estudando o álcool comercial e determinando suas características para as CaCs ${ }^{(21)}$.

Como se pode ver resumidamente acima, temos no Brasil pesquisadores e investidores motivados a desenvolver CaCs genuinamente nacionais. É importante um incentivo de maior parte do governo brasileiro para que estes atuais e futuros projetos rendam frutos para o nosso país ${ }^{(20)}$.

Com grande capacidade hidráulica e sucro-alcooleira, o Brasil poderá produzir $\mathrm{H}_{2}$ para exportar e utilizar em suas próprias CaCs. Um trabalho de conscientização nas escolas deve ser feito para motivar os jovens brasileiros da importância que a energia e o meio ambiente terão no futuro deles, da nossa nação e de todo o planeta ${ }^{(20,39)}$.

\subsection{Células a Combustível de Óxido Sólido}

\subsubsection{Breve evolução histórica}

As CaCs cerâmicas vieram 60 anos depois dos princípios reportados por WILLIAM ROBERT GROVE, em 1839, e se iniciaram com a descoberta do

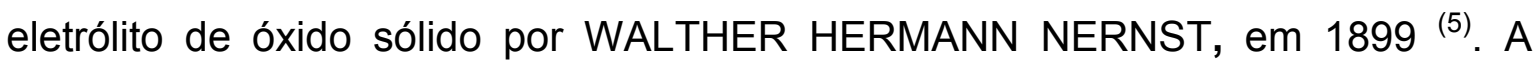
primeira suposta SOFC operando a, aproximadamente, $1000^{\circ} \mathrm{C}$ foi feita por EMIL BAUR e H. PREIS em $1937^{(5,22,25)}$.

As SOFCs somente começaram a despertar interesse como fonte na produção de energia elétrica após a crise energética da década de 1970. Porém, 
com a atual preocupação ambiental e a busca por fontes alternativas, as SOFCs despontam como fortes candidatas, por possibilitarem a geração de energia elétrica de alta potência de uma maneira eficiente, econômica, segura, silenciosa e ecologicamente limpa ${ }^{(10,25)}$.

Atualmente, as SOFCs são divididas em duas classes distintas, de acordo com a temperatura de operação. A primeira classe é conhecida como Célula a Combustível de Óxido Sólido de Temperatura Alta (HTSOFC: High Temperature Solid Oxide Fuel Cell), que opera entre 800 e $1000^{\circ} \mathrm{C}{ }^{(5)}$.

Entretanto, não tendo sido superados todos os problemas que ocorrem nos componentes, devido à alta temperatura de operação, os pequisadores continuam buscando por novos materiais que sejam compatíveis para operacionalizar as CaCs em altas temperaturas, como também em temperaturas consideradas intermediárias ${ }^{(5,10)}$.

Em virtude dos motivos citados, a atenção vem sendo direcionada também para a seleção e obtenção de materiais cerâmicos para serem utilizados como componentes na segunda classe de SOFC; a Célula a Combustível de Óxido Sólido de Temperatura Intermediária (ITSOFC: Intermediate Temperature Solid Oxide Fuel Cell), que opera entre 500 e $800^{\circ} \mathrm{C}^{(5)}$.

\subsubsection{O conceito}

As SOFCs, como todas as CaCs, são dispositivos que convertem diretamente a energia química de uma determinada reação utilizando a combinação entre um oxidante e um combustível para gerar energia elétrica, energia térmica e vapor de água ${ }^{(5,41)}$.

A unidade básica (uma célula unitária) da SOFC consiste de uma camada de eletrólito denso em contato com um anodo e um catodo, um de cada lado e ambos porosos. $\mathrm{O}$ anodo é alimentado continuamente com um combustível, enquanto o catodo recebe o oxidante. A reação eletroquímica que ocorre nos eletrodos produz uma corrente elétrica ${ }^{(16,17,25,41)}$. 


\subsubsection{Princípio de funcionamento}

As SOFCs têm basicamente o mesmo princípio de funcionamento que os outros tipos de $\mathrm{CaCs}$, mas com algumas diferenças. Estas células são compostas por dois eletrodos cerâmicos porosos e separados por um eletrólito também cerâmico e denso, que deve ser um material impermeável que permita movimento aos íons negativos entre os dois eletrodos ${ }^{(25)}$. Normalmente, como se utiliza o oxigênio puro ou o ar como elemento oxidante, os íons negativos de oxigênio serão conduzidos do catodo até o anodo através do eletrólito ${ }^{(25,41)}$.

Dentro da SOFC, o gás $\mathrm{H}_{2}$ pressurizado é bombeado para o terminal negativo, o anodo. Do outro lado, $\circ \mathrm{O}_{2}$, puro ou extraído do ar, entra na célula pelo terminal positivo, o catodo. A molécula de oxigênio é convertida em íons negativos de oxigênio $\left(\mathrm{O}^{2-}\right)$. Os íons $\mathrm{O}^{2-}$ migram até o anodo através do eletrólito ${ }^{(C)}$ e se combinam com a molécula de $\mathrm{H}_{2}$ localizada no anodo ${ }^{(\mathrm{D})}$ para formar a molécula de água $\left(\mathrm{H}_{2} \mathrm{O}\right)$ e dois elétrons $\left(\mathrm{e}^{-}\right)^{(16,17,25)}$ :

$$
\begin{gathered}
1 / 2 \mathrm{O}_{2(\mathrm{~g})}+2 \mathrm{e}^{-} \Rightarrow \mathrm{O}^{2-} \quad \text { (Catodo) } \\
\mathrm{H}_{2(\mathrm{~g})}+\mathrm{O}^{2-} \Rightarrow \mathrm{H}_{2} \mathrm{O}_{(\mathrm{l})}+2 \mathrm{e}^{-} \quad \text { (Anodo) }
\end{gathered}
$$

Nesta tecnologia, devido à alta temperatura de operação, entre $800 \mathrm{e}$ $1000{ }^{\circ} \mathrm{C}$ para a HTSOFC e entre 500 e $800{ }^{\circ} \mathrm{C}$ para a ITSOFC, a reforma do combustível é feita internamente. A Figura 3.14 mostra uma ilustração do funcionamento de uma SOFC unitária ${ }^{(42)}$.

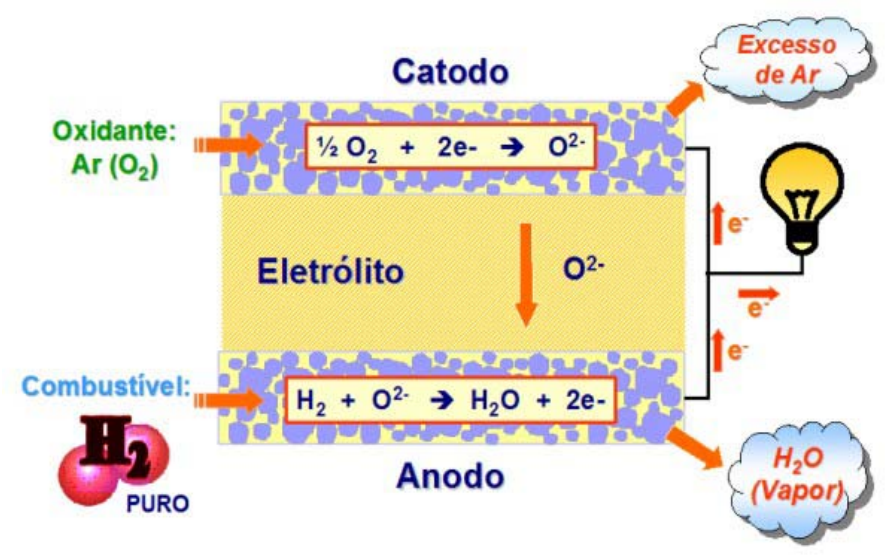

Figura 3.14 - Esquema do funcionamento de uma SOFC unitária ${ }^{(42)}$. 


\subsubsection{Principais componentes}

As SOFCs, assim como os demais tipos de CaCs, possuem componentes extremamente importantes para o seu correto funcionamento e para o seu desempenho durante a operação ${ }^{(43-48)}$.

Igualmente às outras tecnologias, os três componentes principais são: o catodo, o anodo e o eletrólito. Entretanto, para a fabricação de stacks (Figura 3.15), é muito importante o estudo do interconector, que possui o a função de conectar o catodo de uma célula ao anodo da célula seguinte, com o objetivo de empilhar as células unitárias e também do selante, que possui a função de vedar a célula, devido à operação em temperaturas superiores a $500^{\circ} \mathrm{C}{ }^{(43,44)}$.

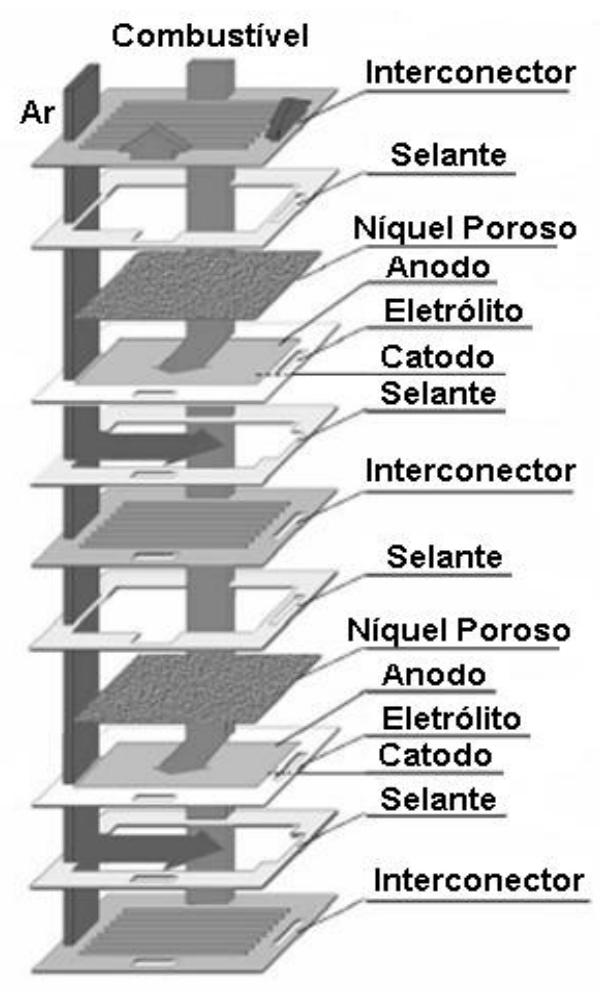

Figura 3.15 - Representação ilustrativa de um stack de SOFC ${ }^{(5)}$.

Os componentes das HTSOFCs mais comuns são a zircônia estabilizada com $8 \%$ em mol de ítria $\left(\mathrm{ZrO}_{2} / \mathrm{Y}_{2} \mathrm{O}_{3}-\mathrm{YSZ}\right)$ como eletrólito; o manganito de lantânio dopado com estrôncio $\left(\mathrm{LaSrMnO}_{3}-\mathrm{LSM}\right)$ como catodo; o cermet zircônia - ítria - níquel $\left(\mathrm{ZrO}_{2} / \mathrm{Y}_{2} \mathrm{O}_{3} / \mathrm{Ni}\right.$ - YSZ/Ni) como anodo; o cromito de lantânio $\left(\mathrm{LaCrO}_{3}-\mathrm{LC}\right)$ dopado geralmente com estrôncio (Sr), e/ou cobalto (Co) como interconector e materiais vitrocerâmicos como selante ${ }^{(43-48)}$. 
Em particular, nos manganitos como catodo das SOFCs, a dopagem do $\mathrm{LnMnO}_{3}(\mathrm{Ln}=\mathrm{La}, \mathrm{Nd}, \mathrm{Pr}, \mathrm{Ce}, \mathrm{Sm}$ e Gd) com Sr, aumenta a condutividade elétrica do material, pois ocorre o aumento de cátions $\mathrm{Mn}^{4+}$, através da substituição de cátions $\mathrm{Ln}^{3+}$ por cátions $\mathrm{Sr}^{2+}$. Isso torna o $\mathrm{LnSrMnO}_{3}$ um dos sistemas preferencialmente utilizados como material catódico ${ }^{(43-48)}$.

Atualmente, o material LSM é o material catódico mais utilizado para utilização em HTSOFCs e também o mais consolidado, devido ao seu excelente desempenho eletroquímico, à sua estabilidade química e térmica e à sua compatibilidade química e mecânica com o eletrólito sólido de $Y S Z{ }^{(10,24)}$.

Entretanto, o LSM, apresenta alta resistência de condução iônica em temperaturas mais baixas devido à sua pobre condução dos íons oxigênio, e o seu desempenho como eletrodo é melhorado somente se existirem duas camadas do catodo; uma formada no substrato YSZ, usualmente do compósito YSZ/LSM e a outra constituída de uma camada de $\operatorname{LSM}^{(9,10)}$.

Em virtude, principalmente, destes problemas mencionados, e aos relacionados com o custo de manufatura, da escolha limitada de materiais e da degradação dos componentes que operam em altas temperaturas, vários esforços estão concentrados na utilização de materiais que operam adequadamente em temperaturas intermediárias tais como sistemas que contêm neodímio $(\mathrm{Nd})$, praseodímio $(\mathrm{Pr})$, cério $(\mathrm{Ce})$, gadolínio $(\mathrm{Gd})$, samário $(\mathrm{Sm})$, entre outros ${ }^{(7,49)}$.

A operação em temperaturas intermediárias resolve alguns problemas associados com a fabricação e com os materiais envolvidos, melhorando a confiabilidade da própria célula durante uma operação mais prolongada ${ }^{(26,50)}$. Algumas ITSOFCs com metanol direto como combustível e que operam em torno de $500{ }^{\circ} \mathrm{C}$ vêm contribuindo significativamente para as pesquisas nesta área ${ }^{(21)}$.

\subsubsection{Principais configurações}

A SOFC, além de ser classificada de acordo com a sua temperatura de operação, possui também concepções variadas de acordo com a sua configuração geométrica ${ }^{(50-53)}$ :

- pSOFC (planar Solid Oxide Fuel Cell): célula a combustível de óxido sólido na forma planar retangular; 
- cSOFC (circular Solid Oxide Fuel Cell): célula a combustível de óxido sólido na forma planar circular;

- tSOFC (tubular Solid Oxide Fuel Cell): célula a combustível de óxido sólido na forma tubular;

- mSOFC (monilitic Solid Oxide Fuel Cell): célula a combustível de óxido sólido na forma monolítica;

- sSOFC (segmented Solid Oxide Fuel Cell): célula a combustível de óxido sólido na forma segmentada.

As configurações planar retangular e tubular são as mais consolidadas atualmente $^{(51-53)}$. As Figuras 3.16 a 3.18 mostram representações ilustrativas das configurações que estão sendo estudadas atualmente para as SOFCs ${ }^{(50-53)}$.

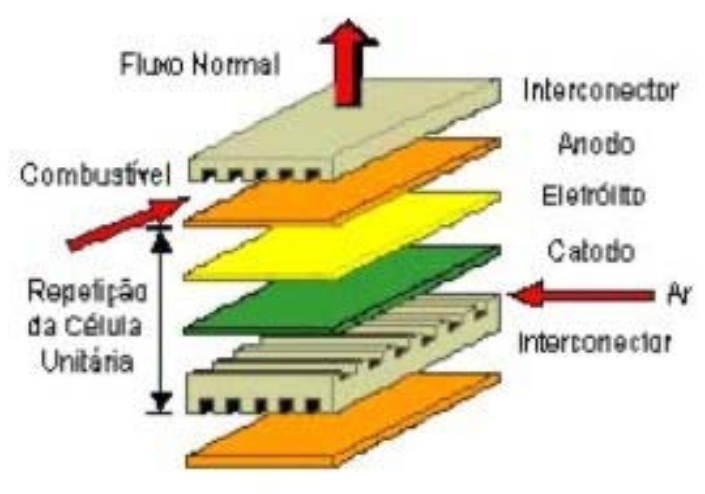

(a)

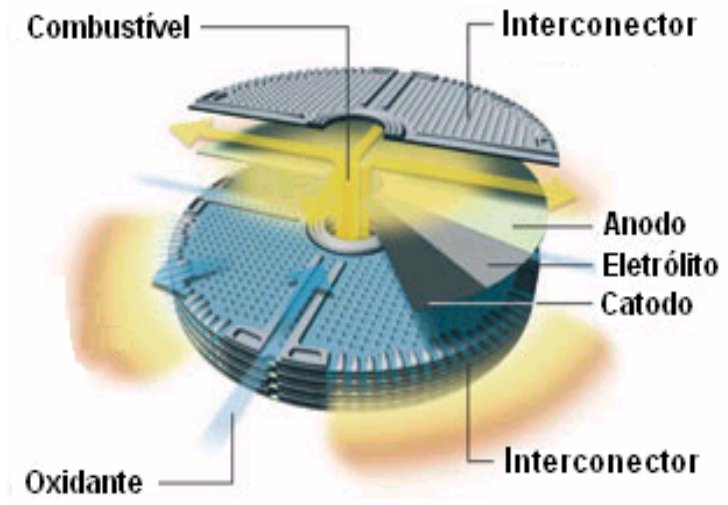

(b)

Figura 3.16 - Ilustrações de uma SOFC planar retangular (a) e planar circular (b) ${ }^{(9,50)}$.

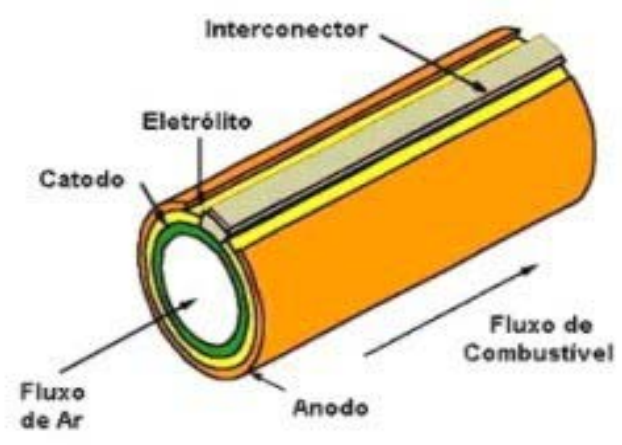

Figura 3.17 - llustração de uma SOFC tubular ${ }^{(51,52)}$. 

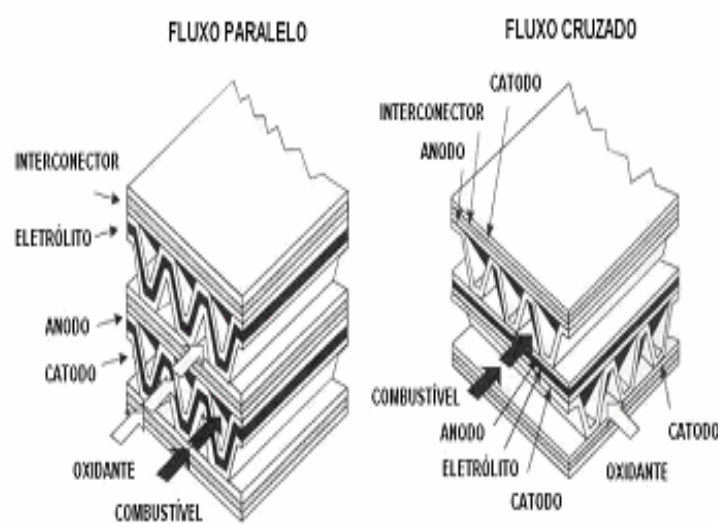

(a)

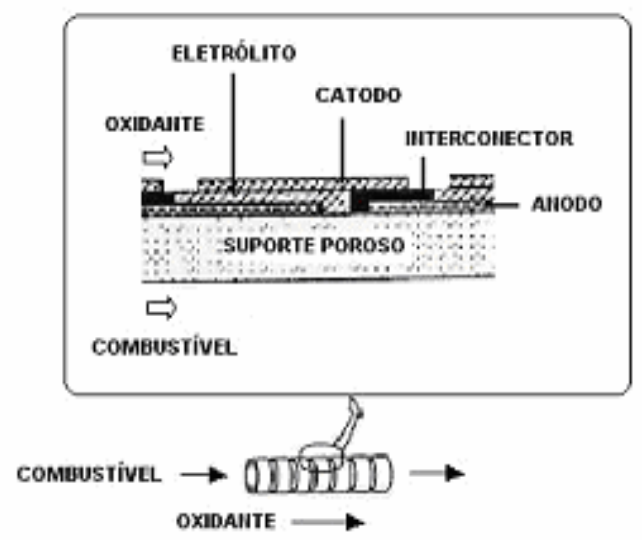

(b)

Figura 3.18 - llustrações de uma SOFC monolítica (a) e segmentada (b) ${ }^{(53)}$.

\subsubsection{Aplicações estacionárias}

Embora existam pesquisas com SOFCs para aplicações móveis e até portáteis (Micro-SOFCs), a grande aposta para este tipo de tecnologia serão as aplicações estacionárias de médio porte, para uso comercial e de grande porte, para uso principalmente industrial (Figura 3.19), mas podendo ser aplicada também para aplicações estacionárias de pequeno porte, para uso residencial ${ }^{(25)}$.

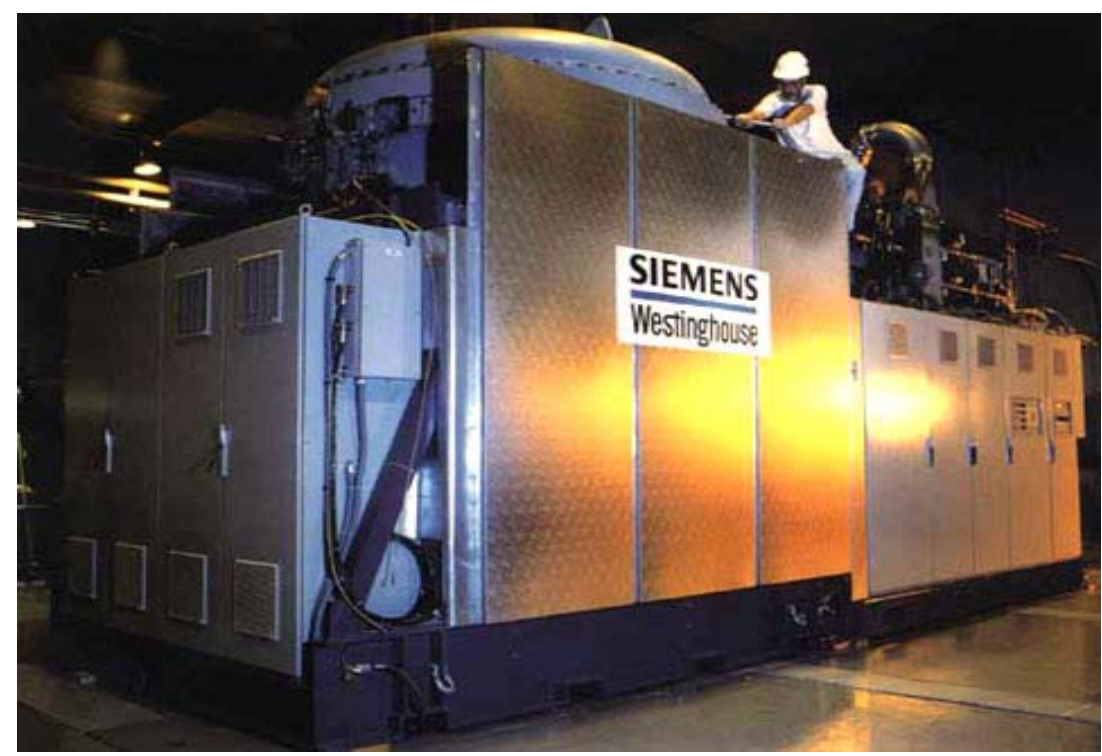

Figura 3.20 - llustração de módulo de SOFC industrial ${ }^{(54)}$. 
3.2.7. Célula a combustível de óxido sólido de temperatura intermediária

Como apresentado anteriormente, a ITSOFC é um tipo de SOFC que opera em temperaturas intermediárias, entre 500 e $800{ }^{\circ} \mathrm{C}$. Devido a operações em temperaturas menores, se comparada a HTSOFC, este tipo de célula requer materiais particulares para todos os seus componentes e possui vantagens e desvantagens ao se trabalhar nesta faixa de temperatura ${ }^{(5,25)}$.

Os principais componentes de uma ITSOFC são: eletrólito, catodo, anodo e o interconector. Todos devem atender a certos requisitos para serem utilizados nos stacks, como ter propriedades químicas, morfológicas e dimensionais bem estabilizadas em ambientes redutores ou oxidantes, boa compatibilidade química e ótimas propriedades elétricas ${ }^{(5,25)}$.

Os componentes dessas células devem ainda ter coeficientes de expansão térmica próximos para evitar separação e quebra durante a fabricação e operação. O eletrólito e o interconector devem ser densos, prevenindo a mistura de gases, enquanto o anodo e o catodo devem ser porosos para permitir a passagem dos gases às regiões de reação ${ }^{(5,25)}$.

Para as ITSOFCs, ainda existe uma grande quantidade de componentes que estão sendo pesquisados. Dentre estes componentes temos o cério dopado, ou galato de lantânio dopado como eletrólito, cobaltitos férricos e manganitos dopados como catodo; o cermet zircônia - ítria - cobre $\left(\mathrm{ZrO}_{2} / \mathrm{Y}_{2} \mathrm{O}_{3} / \mathrm{Cu}\right.$ - YSZ/Cu) ou manganitos dopados com Sr e Cromo (Cr), como anodo, alguns cermets ou ligas metálicas de Ferro $(\mathrm{Fe}) \mathrm{com} \mathrm{Cr}$ como interconector e materiais vitrocerâmicos como selante ${ }^{(5,26,55)}$.

\subsubsection{Vantagens e desvantagens da ITSOFC}

A ITSOFC combina todas as vantagens da tecnologia desenvolvida com a HTSOFC para a operação em temperaturas consideradas intermediárias (500 a $800^{\circ} \mathrm{C}$ ). Atualmente, muitos componentes cerâmicos são utilizados como eletrodo e eletrólito, pois o carbono não se deposita em material cerâmico e o combustível da célula pode conter hidrocarbonetos e CO ${ }^{(26,55)}$. 
Além disso, não existe o problema da degradação inerente ao eletrólito líquido. O processo interno de reforma do combustível é prático a partir de $650{ }^{\circ} \mathrm{C}$. As vantagens na utilização de temperaturas intermediárias são ${ }^{(21)}$ :

- Reforma e remoção de enxofre: melhora o equilíbrio térmico do processo;

- Menos precipitação e arraste de material no interior da célula: ajuda a manter a área de superfície da reação;

- Menor tensão térmica, pois a temperatura de operação mais baixa permite a utilização de menos material, aumentando a área de resistência específica e facilitando a selagem da estrutura;

- Maior flexibilidade de material, pois a disponibilidade de materiais é maior em temperatura intermediária;

- Menor perda de calor para níveis similares de isolação;

- Menor tempo para atingir a temperatura de operação;

- Permite a aplicação de processos por ativação térmica.

A temperatura de operação mais baixa permite a construção da célula em aço inoxidável, o que representa menor custo de fabricação em relação aos metais mais nobres. As desvantagens dessa tecnologia estão na condutividade do eletrólito e na dinâmica do eletrodo, que diminuem significativamente em temperaturas menores que $800{ }^{\circ} \mathrm{C}$. Para tentar superar estas desvantagens, outros materiais alternativos estão sendo pesquisados e testados ${ }^{(26,55)}$.

\subsubsection{Pesquisa e desenvolvimento no Brasil}

As SOFCs estão cada vez mais sendo estudadas e pesquisas por institutos de pesquisas, universidades, companhias estatais e federais de energia elétrica em todo o Brasil ${ }^{(21)}$.

Entretanto, se compararmos o atual estágio da pesquisa com SOFCs no Brasil em relação a alguns países, é constatado que temos muito caminho a percorrer para desenvolver realmente esta tecnologia promissora ${ }^{(21)}$.

Todavia, a comunidade científica brasileira que trabalha com SOFCs está crescendo de forma significativa a cada ano e organizando eventos e congressos para a disseminação das pesquisas em todo o território nacional ${ }^{(21)}$. 
Isso demonstra que, embora ainda relativamente pequena, a comunidade científica está trabalhando e gerando conhecimento científico e tecnológico sobre as SOFCs. Nos últimos três anos, foram aprovados diversos projetos de pesquisas pelos Fundos Setoriais, além do projeto estruturante da Rede PaCOS (Rede de Pilhas a Combustível de Óxido Sólido), financiado pela FINEP e incluindo bolsas do CNPq. Tudo isso é resultado de uma ação conjunta e consistente, da própria comunidade científica e do MCT, através do seu Programa de Ciência, Tecnologia e Inovação para a Economia do Hidrogênio ${ }^{(56)}$.

O Brasil é uma potência mundial na produção e tecnologia do etanol (álcool) e tem tudo para conseguir produzir e até exportar as suas próprias SOFCs, seja utilizando diretamente o etanol como combustível, ou reformando para a produção de hidrogênio ${ }^{(21,39)}$.

\subsection{O Catodo}

Os estudos dos principais componentes de uma SOFC unitária são extremamente importantes, mas como o objetivo deste trabalho está diretamente relacionado ao catodo de uma ITSOFC, este será amplamente discutido.

O catodo opera em meio oxidante, geralmente ar ou oxigênio puro em temperaturas entre 500 e $800^{\circ} \mathrm{C}$, mais efetivamente a partir de $650{ }^{\circ} \mathrm{C}$ e participa diretamente na reação de redução do $\mathrm{O}_{2}(\mathrm{E})^{(16,17,25)}$ :

$$
1 / 2 \mathrm{O}_{2(\mathrm{~g})}+2 \mathrm{e}^{-} \Rightarrow \mathrm{O}^{2-}
$$

Nesta situação, $\mathrm{o} \mathrm{O}_{2}$ é reduzido para íons de oxigênio $\left(\mathrm{O}^{2-}\right)$, consumindo dois elétrons $\left(\mathrm{e}^{-}\right)$durante o processo. Um catodo promissor para as

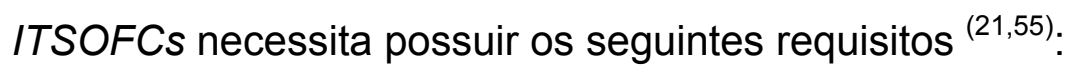

- Alta condutividade eletrônica;

- Estabilidade dimensional e química durante a operação da célula e durante a fabricação do interconector, eletrólito e camadas do anodo;

- Expansão térmica próxima com a dos outros componentes da célula;

- Compatibilidade e reatividade adequadas com o eletrólito e o interconector em que o catodo está em contato; 
- Porosidade suficiente para facilitar o transporte do $\mathrm{O}_{2}$ para a interface catodo/eletrólito.

Para satisfazer estes requisitos, o material deve ser convenientemente dopado com elementos alcalinos. O material catódico pode ter excesso ou deficiência de $\mathrm{O}_{2}$ dependendo da sua pressão parcial e da temperatura de operação em que a célula será solicitada ${ }^{(10)}$.

O interesse pelos parâmetros microestruturais está relacionado diretamente à determinação da área ativa eletroquimicamente, que é conhecida como tripla fase reacional (three phase boundary line - TPBL), que é a região onde o eletrodo (neste caso o catodo), o eletrólito e a fase gasosa $\left(\mathrm{O}_{2}\right)$ estão em contato (Figura 3.20) ${ }^{(5,22,25)}$.

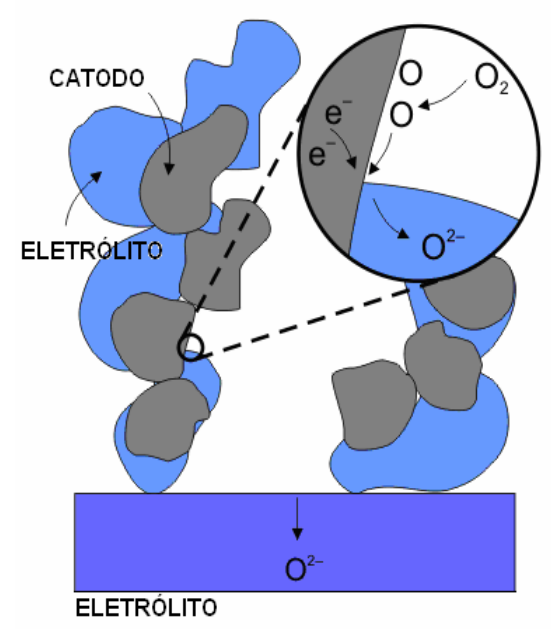

Figura 3.20 - Representação ilustrativa da tripla fase reacional ${ }^{(5)}$.

Várias pesquisas têm sido conduzidas para se verificar qual o melhor método de obtenção do material catódico das ITSOFCs, sendo que o mais importante é conseguir controlar de forma efetiva as seguintes variáveis que influenciam o processo de fabricação ${ }^{(16,17)}$ :

- Composição do manganito;

- Preparação e obtenção dos precursores;

- Temperaturas de calcinação e sinterização;

- Processo de conformação de suspensões. 
O controle das variáveis acima citados tem como objetivo a obtenção de uma microestrutura controlada com tamanho médio de partículas homogêneas e distribuição de fases constante, aumentando a região da TPBL ${ }^{(16,17)}$.

Embora tenham sido realizados vários estudos sobre os eletrodos catódicos, muitas pesquisas continuam para tentar completar o entendimento do mecanismo de reação, bastante complexo devido à composição, microestrutura, morfologia e formação de vacâncias de íons $\mathrm{O}_{2}$ no catodo cerâmico ${ }^{(16,17)}$.

Além disso, o material catódico deve ser estável em atmosfera oxidante, ter condutividade eletrônica de pelo menos $50 \Omega^{-1} \mathrm{~cm}^{-1}$, ter nível de porosidade entre 25 e 35 \% e exibir boa atividade para a redução do oxigênio em condições normais de operação ${ }^{(16,17)}$.

O perfil de redução no aquecimento e o coeficiente de expansão térmica devem ser compatíveis com os outros componentes da célula. O LSM, que é constantemente utilizado como material catódico para as HTSOFCs tem uma condutividade elétrica de aproximadamente $80 \Omega^{-1} \mathrm{~cm}^{-1}$ a $1000{ }^{\circ} \mathrm{C}$ e é estável em ambiente oxidante ${ }^{(25)}$. O NSM deve ter condutividade elétrica de aproximadamente $40 \Omega^{-1} \mathrm{~cm}^{-1}$ entre 650 e $800{ }^{\circ} \mathrm{C}{ }^{(55)}$.

Pelo controle cuidadoso da estequiometria e das características do pó, outras propriedades, tais como o perfil de redução no aquecimento, a expansão térmica e a porosidade, podem ser adaptadas para se obter uma adequada compatibilidade com os outros componentes da célula ${ }^{(25)}$.

\subsection{Manganito de Neodímio Dopado com Estrôncio}

As estruturas pseudo-perovskitas baseadas no sistema $\mathrm{Nd}_{1-\mathrm{x}} \mathrm{Sr}_{\mathrm{x}} \mathrm{MnO}_{3}$ (NSM), são reconhecidas como um dos mais adequados materiais catódicos para utilização em ITSOFCs, devido ao seu excelente desempenho eletroquímico e às suas ótimas estabilidades química e térmica ${ }^{(7,8,15)}$.

A literatura apresenta trabalhos já realizados sobre os materiais catódicos de manganito de neodímio $\left(\mathrm{NdMnO}_{3}\right)$ sem e com dopagem de $\mathrm{Sr}$ ou $\mathrm{Ca}$. Estes trabalhos mostram que o desempenho do $\mathrm{NdMnO}_{3}$, utilizado nas ITSOFCs, depende da sua composição química e da microestrutura do material (porosidade, espessura do catodo e distribuição do tamanho médio de partícula) ${ }^{(1,8,49)}$. 
Diferentes composições de NSM foram sintetizadas. Dentre estas, citase na literatura o trabalho de SAKAKI, Y.; TAKEDA, Y. e colaboradores ${ }^{(7)}$, que obtiveram $\mathrm{Nd}_{1-x} \mathrm{Sr}_{x} \mathrm{MnO}_{3}$ com " $\mathrm{x}$ " variando entre $0<x \leq 0,5$ utilizando as técnicas de mistura de sólidos e de decomposição térmica dos respectivos nitratos. Por estas técnicas, a calcinação foi realizada a $1000^{\circ} \mathrm{C}$ durante 12 horas e os pós destes materiais foram conformados e sinterizados a $1350{ }^{\circ} \mathrm{C}$ durante 24 horas em atmosfera de ar sintético. Após a sua caracterização, a estrutura ortorrômbica pseudo-perovskita foi encontrada em todas as composições estudadas. Segundo as condições adotadas por estes autores, a condutividade elétrica e o coeficiente de expansão térmica encontrados, demonstraram que o material é um cátodo promissor para as ITSOFCs. Além disso, foram observados o tamanho médio de partículas, a distribuição de tamanho médio e a porosidade do material ${ }^{(7)}$.

No trabalho de TING-LIAN WEN e colaboradores ${ }^{(8)}$, foi obtido o $\mathrm{Nd}_{1-\mathrm{x}} \mathrm{Sr}_{x} \mathrm{MnO}_{3}$ com " $\mathrm{x}$ " variando entre $0<x \leq 0,5$, utilizando o método convencional cerâmico por mistura de sólidos, onde a calcinação foi realizada a $1000{ }^{\circ} \mathrm{C}$ durante 6 horas e os pós foram conformados e sinterizados a $140{ }^{\circ} \mathrm{C}$ durante 4 horas. A estrutura ortorrômbica do tipo pseudo-perovskita foi novamente encontrada em todas as composições estudadas. Segundo as condições adotadas por estes autores, a condutividade elétrica e o coeficiente de expansão térmica encontrados também demonstraram que o material é um catodo promissor para as ITSOFCs ${ }^{(8)}$.

Outros trabalhos realizados, como o de KOSTOGLOUDIS e colaboradores (15), que obtiveram $\mathrm{Pr}_{1-x} \mathrm{Sr}_{x} \mathrm{MnO}_{3}$ (PSM), material semelhante ao NSM, e utilizando a técnica dos citratos, obtiveram um material com estrutura pseudo-perovskita ortorrômbica, com adequada porosidade e boas características térmicas e elétricas para um cátodo de uma ITSOFC ${ }^{(15)}$.

Em muitos outros trabalhos são estudados para o catodo, materiais na forma de $\mathrm{Ln}_{1-\mathrm{x}} \mathrm{Sr}_{\mathrm{x}} \mathrm{MnO}_{3}(\mathrm{Ln}=\mathrm{La}, \mathrm{Nd}, \mathrm{Pr}, \mathrm{Sm}$ e $\mathrm{Gd}$ ) com diversas composições para " $x$ " e diferentes métodos de obtenção desses materiais.

Os métodos de obtenção mais utilizados para a síntese desses materiais são: o método de mistura de sólidos (reação no estado sólido), o método dos citratos (conhecido também como Pechini modificado) e o método da reação por combustão ${ }^{(1,8,15,49)}$. 


\subsection{Estrutura Pseudo-Perovskita}

A estrutura perovskita foi identificada pela primeira vez em materiais ferroelétricos. Muitos compostos ternários de fórmula $\mathrm{ABO}_{3}$, cujos cátions $\mathrm{A}$ e $\mathrm{B}$ diferem consideravelmente no tamanho, cristalizam-se nessa estrutura ${ }^{(57)}$.

Como mostra a Figura $3.21^{(58)}$, a estrutura pode ser considerada uma estrutura derivada da cúbica de face centrada (CFC), onde o cátion A, maior, e o oxigênio (na figura representada pela letra $O$ ) formam um reticulado CFC. $O$ cátion $B$, menor, ocupa algum local dentro do octaedro, normalmente no centro do reticulado em uma estrutura típica e tem somente átomos de oxigênio como seus vizinhos mais próximos. A sua estrutura é cúbica, contendo três íons diferentes na forma $\mathrm{ABO}_{3}$. Os átomos $\mathrm{A}$ e $\mathrm{B}$ representam íons de valências +2 e +4, respectivamente, e o átomo de oxigênio representa seu íon de valência $-2^{(57,58)}$.

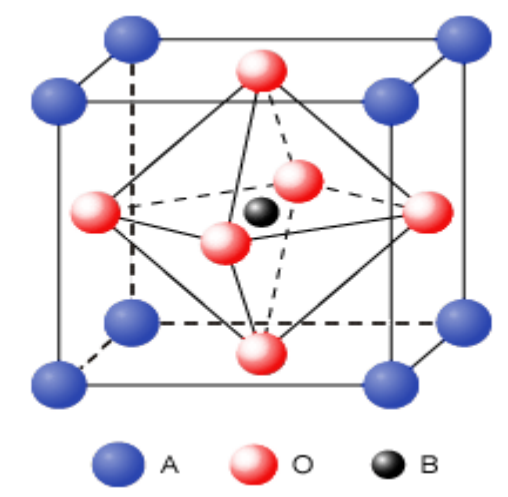

Figura 3.21 - Ilustração representativa da estrutura perovskita ${ }^{(58)}$.

Desta forma, a estrutura de $\mathrm{ABO}_{3}$, em sentido geral, pode ser imaginada com átomos de $\mathrm{A}$ em seus vértices e átomos de $\mathrm{O}$ no centro das faces. $\mathrm{O}$ átomo de $\mathrm{B}$ completa a estrutura, ficando situado no centro do reticulado. $\mathrm{O}$ átomo de $\mathrm{A}$ é o maior dos átomos e aumenta conseqüentemente o tamanho total da estrutura. Em conseqüência, existem algumas posições mínimas de energia descentralizadas do octaedro original que pode ser ocupado pelo átomo de $\mathrm{B}^{(59)}$.

A família das perovskitas inclui muitos titanatos utilizados em aplicações eletrocerâmicas, tais como o $\mathrm{BaTiO}_{3}, \mathrm{CaTiO}_{3}$ (que recebe o nome do mineral perovskita), $\mathrm{SrTiO}_{3}, \mathrm{PbTiO}_{3}$, incluindo zirconatos tais como $\mathrm{PbZrO}_{3}$, $\mathrm{BaZrO}_{3}$, e inúmeros outros compostos como $\mathrm{LaGaO}_{3}, \mathrm{LaAlO}_{3}$ e $\mathrm{KNbO}_{3}{ }^{(60)}$. 
Os materiais utilizados como catodos em SOFCs, como o manganito de lantânio $\left(\mathrm{LaMnO}_{3}\right)$ e o manganito de neodímio $\left(\mathrm{NdMnO}_{3}\right)$ apresentam uma estrutura que deve ser denominada corretamente de pseudo-perovskita ou perovskita distorcida, pois, para formação do material, ocorre uma transformação cristalográfica com conseqüente alteração de volume do cristal. A Figura $3.22^{(24)}$ representa através de uma ilustração, a distorção que ocorre na estrutura cristalina após a formação do NSM ${ }^{(60,61)}$.

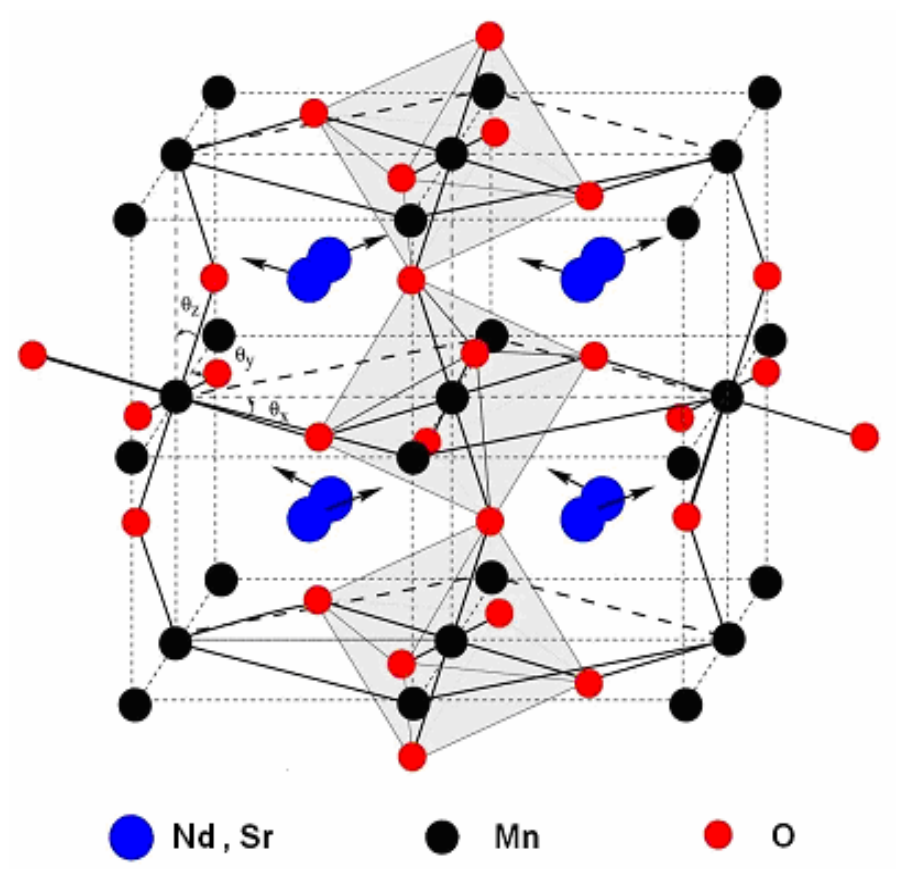

Figura 3.22 - Aspecto da distorção da estrutura perovskita ${ }^{(24)}$.

$\mathrm{Na}$ estrutura do manganito de neodímio, os átomos de neodímio correspondem às posições $A$ (representado nas figuras pela coloração azul), e os átomos de manganês (coloração preta), por sua vez, correspondem às posições B. A utilização de outras espécies, nas posições $A$ e $B$ objetivam melhorar ou modificar uma ou mais propriedades da estrutura inicial. A substituição destas espécies atômicas por outras poderão causar alterações que podem influenciar na transformação de fase, na condutividade elétrica, na estequiometria de oxigênio e na expansão térmica ${ }^{(42,60)}$.

As substituições ocorrem quando dopamos o material, ou seja, são adicionados estequiometricamente elementos que possam substituir tanto os átomos da posição $A$ quanto os da posição $B^{(60,61)}$. 
Entretanto, nem sempre a adição será substitucional, ela pode ocorrer também de forma intersticial, ou seja, acomodando os átomos adicionados entre os espaços vazios existentes na estrutura ${ }^{(60,61)}$.

Os elementos mais empregados nas substituições, ou dopagem, ao $\mathrm{NdMnO}_{3}$ são: $\mathrm{Sr}$ e $\mathrm{Ca}$ no lugar do $\mathrm{Nd}$ (posição $\mathrm{A}$ ), e $\mathrm{Mg}$ no lugar do $\mathrm{Mn}$ (posição B). Para a posição A, ambos os elementos dopantes ( $\mathrm{Sr}$ e $\mathrm{Ca}$ ) proporcionam alta condutividade elétrica para o material ${ }^{(60,61)}$.

\subsection{Mistura de Sólidos}

O método de mistura de sólidos multicomponentes é a reação no estado sólido entre os carbonatos ou óxidos de seus constituintes ${ }^{(62,63)}$. A repetição de ciclos de moagem e calcinação é muitas vezes necessária para se conseguir uma melhor interação entre os elementos químicos presentes. $\mathrm{Na}$ maioria das vezes, temperaturas relativamente altas são necessárias para que as reações no estado sólido aconteçam ${ }^{(62,63)}$.

A moagem deve ser realizada com cuidados, pois pode introduzir contaminantes a partir de seus componentes abrasivos, modificando as características dos materiais produzidos em diferentes lotes ${ }^{(62,63)}$.

Alguns problemas no processamento de soluções sólidas a partir de técnicas que empregam altas temperaturas são as dificuldades de controlar o crescimento dos grãos, segregação dos dopantes e, conseqüentemente, perda de estequiometria devido à volatilização dos reagentes ${ }^{(62,63)}$.

No caso da utilização dos reagentes na forma de óxidos, é importante destacar que reações entre óxidos simples (Figuras 3.23) em altas temperaturas resultam em óxidos não homogêneos ${ }^{(62,63,64)}$.

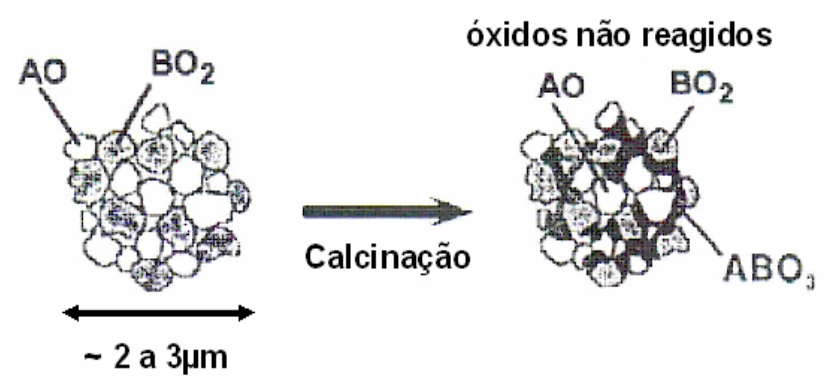

Figura 3.23 - Problema encontrado na mistura de sólidos com utilização de óxidos ${ }^{(64)}$. 
A mistura de sólidos também apresenta vantagens importantes, pois é um método tradicional de síntese de materiais cerâmicos e apesar de possuir etapas relativamente longas, são de simples execução. Este método ainda é muito utilizado industrialmente, pois apresenta baixo custo e boa reprodutibilidade, se as etapas forem realizadas com cuidado e atenção ${ }^{(63,64)}$.

\subsection{Calcinação}

A calcinação é uma operação que consiste em transformar, por efeito do calor, carbonatos ou quaisquer metais em óxidos de seus elementos químicos. É um processo de tratamento térmico em que se oxidam as substâncias presentes em uma determinada amostra utilizando temperaturas elevadas. Normalmente são realizadas em laboratório, com uso de um forno mufla, e na industria em fornos aquecidos por óleo, como na produção de cimento ${ }^{(58,59)}$.

Normalmente, as calcinações ocorrem em temperaturas da ordem de $1000^{\circ} \mathrm{C}$ e são utilizadas para preparar os materiais para posteriores análises químicas de substâncias complexas ou para a quantificação de metais, pois a maior parte dos óxidos metálicos se mantêm estáveis a altas temperaturas. Depois de trabsformada a óxidos, pode-se analisar as amostras com o uso de outras técnicas, principalmente volumétricas e instrumentais ${ }^{(58,59)}$.

Para os materiais cerâmicos utilizados como componentes em SOFCs, a calcinação é realizada com a finalidade de sintetizar o material desejado, além de reduzir parte do teor de carbono presente na amostra, quando se utilizam reagentes na forma de carbonatos ${ }^{(58,59)}$.

\subsection{Sinterização}

A sinterização pode ser descrita como um processo no quais, pós cristalinos ou não, compactados, são tratados termicamente em uma temperatura ligeiramente acima da metade da temperatura de fusão, envolvendo mudança na microestrutura desse material, por meio de um ou mais mecanismos de transporte de massa, para se obter um único sólido coerente e homogêneo ${ }^{(65-69)}$.

Durante o processo de sinterização no estado sólido, as reações são termicamente ativadas e algumas dessas reações ocorrem espontaneamente 
quando uma determinada temperatura é atingida. Outras reações ocorrem lentamente em amplo intervalo de temperatura e somente entre as partículas em contato. Neste caso, não só a temperatura, mas também o tamanho de partícula e a área de contato entre elas são de extrema importância ${ }^{(65,66)}$.

$\mathrm{Na}$ produção de cerâmicas à base de manganês, o fenômeno de sinterização mais importante é a sinterização no estado sólido ${ }^{(68)}$. Este evento é preferível na produção de cerâmicas com boas propriedades mecânicas, e elétricas. $\mathrm{Na}$ sinterização, os constituintes do material em forma de pó, posteriormente compactado, permanecem sólidos durante todo o processo ${ }^{(65,66)}$.

A densificação máxima do material é atingida pela mudança na forma dos grãos constituintes. A variável mais importante da sinterização é a redução da energia livre de superfície do sistema, ou seja, a tendência do sistema em atingir o estado de menor energia livre, onde é acompanhada por uma redução nas áreas das superfícies e interfaces dos compactados, sendo que isso se consegue pela transformação de muitas partículas pequenas em maiores, ocorrendo o crescimento de grão e a substituição das interfaces gás-sólido, por sólido-sólido de menor energia ${ }^{(65,66)}$.

O estudo da sinterização é geralmente simplificado, assumindo que o processo ocorre em três estágios: inicial, intermediário e final (Figuras 3.24).

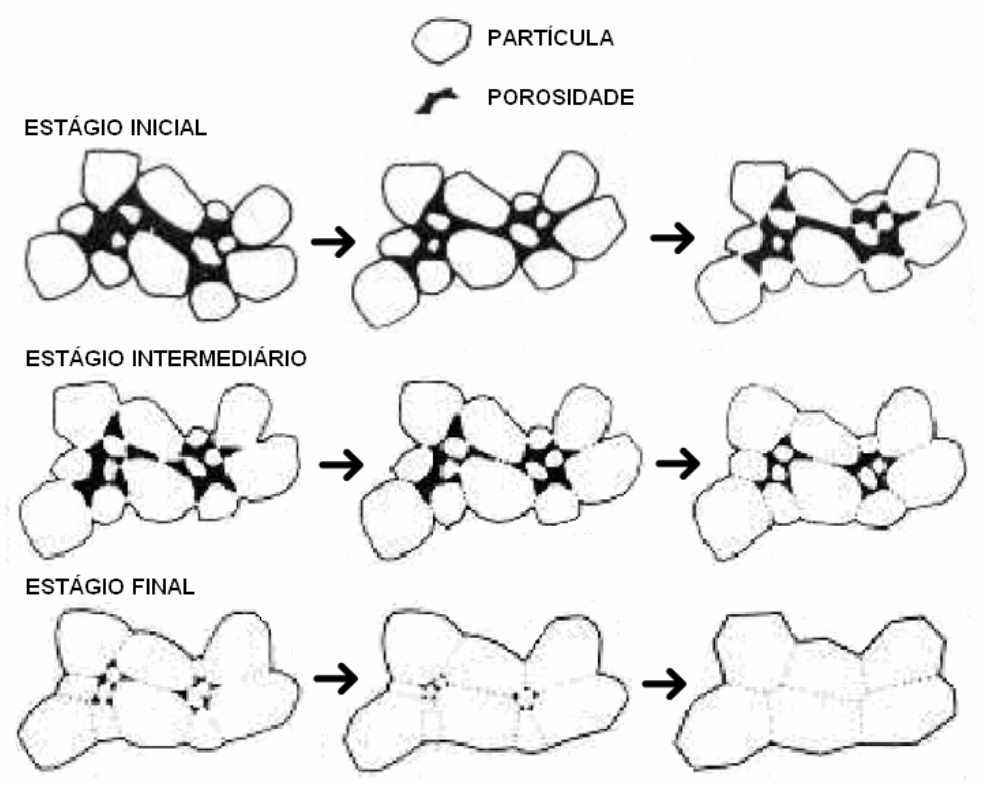

Figura 3.24 - Representação ilustrativa dos estágios da sinterização ${ }^{(68)}$. 
Não existe uma diferenciação clara entre os três estágios e alguns autores chegam a omitir o estágio intermediário ${ }^{(29)}$. Vários modelos têm sido propostos com a finalidade de determinar o mecanismo, ou os mecanismos, responsáveis pela sinterização ${ }^{(66,67)}$.

No estágio inicial ocorre o rearranjo das partículas e início da formação de pescoços entre os pontos de contato. Este rearranjo consiste em leves movimentos ou rotações das partículas adjacentes, causando um aumento no número de pontos de contato. No primeiro estágio a porosidade é relativamente grande. No segundo estágio há uma redução na porosidade e os centros de massa das partículas iniciais se aproximam. No terceiro estágio ocorre à remoção da porosidade por difusão, utilizando o mecanismo de transporte de massa ao longo dos contornos de grão. Entretanto, como o catodo necessita possuir porosidade, a sinterização deve ser controlada para que não ocorra a eliminação dessa porosidade requerida ${ }^{(66,67)}$.

Os materiais a base de manganês têm recebido relativamente pouca atenção em termos de estudos de sua cinética de sinterização e, que raramente se encontram trabalhos onde os modelos são aplicados ou propostos especificadamente para a sinterização destes materiais, sendo a ênfase dada no estudo da otimização dos processos de sinterização ${ }^{(67)}$.

O crescimento de grão ocorre em todos os estágios de sinterização. 0 modelo mais simples de crescimento de grão leva em consideração o movimento dos contornos de grão, que é inversamente proporcional ao tamanho médio do grão. Dessa forma a segregação de impurezas nos contornos de grão pode reduzir a energia livre do sistema e, conseqüentemente, diminuir a taxa de crescimento do grão, influenciando diretamente na sinterização ${ }^{(58,59,66,67)}$.

\subsection{Dilatação Térmica}

Todos os corpos na natureza estão sujeitos a dilatação térmica, alguns mais, outros menos. Geralmente, quando aquecemos um corpo, ou uma substância, este tende a aumentar o volume (expansão térmica). Se esfriarmos um corpo ou substância, este tende a diminuir seu volume (contração térmica) ${ }^{(70)}$.

Existem alguns materiais que, em condições especiais, fazem 0 contrário: quando esquentam contraem e quando esfriam dilatam. É o caso da 
água quando está entre 0 e $4{ }^{\circ} \mathrm{C}{ }^{(70)}$. Mas estes casos são exceções e, apesar de importantes, não serão descritos neste trabalho.

Quando aquecemos algum material estamos aumentando a agitação de suas moléculas e isso faz com que elas se afastem umas das outras, aumentando o espaço entre elas. Para uma molécula é mais fácil, quando esta vibra com maior intensidade, afastar-se das suas vizinhas do que se aproximar delas. Isto acontece por causa da maneira como as forças moleculares agem no interior da matéria. Com isso, se o espaço entre elas aumenta, o volume final do corpo acaba aumentando proporcionalmente ${ }^{(70)}$.

Quando esfriamos algum material ocorre exatamente o inverso, pois diminuímos as suas agitações internas, fazendo com que o espaço entre as moléculas diminua, ocasionando uma redução do volume do corpo ${ }^{(70)}$.

Existem três equações simples para determinar o quanto um corpo varia de tamanho e, cada uma delas, deve ser utilizada em uma situação diferente (70). A primeira equação (1) corresponde à dilatação térmica linear, a segunda (2) à dilatação térmica superficial e a terceira (3) à dilatação térmica volumétrica:

$$
\Delta \mathrm{L}=\mathrm{Lo} \cdot \alpha \cdot \Delta \mathrm{T} \quad \text { (1) } \quad \Delta \mathrm{A}=\mathrm{Ao} \cdot \beta \cdot \Delta \mathrm{T} \quad \text { (2) } \quad \Delta \mathrm{V}=\mathrm{Vo} \cdot \mathrm{Y} \cdot \Delta \mathrm{T}
$$

Onde:

$$
\begin{aligned}
& \Delta \mathrm{L}=\text { o quanto o corpo aumentou seu comprimento }(\mathrm{m}) ; \\
& \mathrm{Lo}=\text { comprimento inicial do corpo }(\mathrm{m}) ; \\
& \alpha=\text { coeficiente de dilatação linear }\left({ }^{\circ} \mathrm{C}^{-1}\right) ; \\
& \Delta \mathrm{T}=\text { variação da temperatura: } \mathrm{T}_{\text {final }}-\mathrm{T}_{\text {inicial }}\left({ }^{\circ} \mathrm{C}\right) ; \\
& \Delta \mathrm{A}=\text { o quanto o corpo aumentou sua área }\left(\mathrm{m}^{2}\right) ; \\
& \mathrm{Ao}=\text { área inicial do corpo }\left(\mathrm{m}^{2}\right) ; \\
& \beta=\text { coeficiente de dilatação superficial }\left({ }^{\circ} \mathrm{C}^{-1}\right) ; \\
& \Delta \mathrm{V}=\text { o quanto o corpo aumentou seu volume }\left(\mathrm{m}^{3}\right) ; \\
& \mathrm{Vo}=\text { volume inicial do corpo }\left(\mathrm{m}^{3}\right) ; \\
& \mathrm{Y}=\text { coeficiente de dilatação volumétrico }\left({ }^{\circ} \mathrm{C}^{-1}\right)
\end{aligned}
$$

O coeficiente de dilatação linear ( $\alpha$ ) é um número que depende de cada material. Com esse número podemos comparar qual substância dilata ou contrai 
mais do que a outra. Quanto maior for o a da substância mais facilidade ela terá para aumentar seu tamanho quando aquecida, ou diminuir, quando esfriada ${ }^{(70)}$.

Outra coisa importante é que, se soubermos o valor do a de um determinado material, poderemos determinar o valor do coeficiente de dilatação superficial $(\beta)$ e do coeficiente de dilatação volumétrica $(\gamma)$ do mesmo material, pois eles se relacionam da seguinte maneira ${ }^{(70)}$ :

$$
\beta=2 . \alpha \quad(4) \quad y=3 \cdot \alpha
$$

\subsection{Condutividade Elétrica}

A condutividade elétrica é utilizada para especificar o caráter elétrico e, é recíproca da resistividade, ou seja, inversamente proporcional e indicativa da facilidade com que um material é capaz de conduzir uma corrente elétrica ${ }^{(71)}$.

Os materiais sólidos exibem uma grande faixa de condutividades. De fato, uma maneira de classificar materiais sólidos é de acordo com a facilidade com que conduzem uma corrente elétrica. Dentro desta classificação existem três importantes grupos: os condutores, os semicondutores e os isolantes ${ }^{(71)}$.

Os metais são bons condutores, tipicamente tendo condutividades da ordem de $10^{7} \Omega^{-1} \mathrm{~m}^{-1}$. No outro extremo estão os materiais com baixas condutividades, situando-se entre $10^{-10}$ e $10^{-20} \Omega^{-1} \mathrm{~m}^{-1}$, que são os isolantes elétricos. Os materiais com condutividades intermediárias, geralmente entre $10^{-6} \mathrm{e}$ $10^{4} \Omega^{-1} \mathrm{~m}^{-1}$, são denominados semicondutores. No Sistema Internacional de Unidades (SI), a condutividade elétrica é medida em siemens por metro $(\mathrm{S} / \mathrm{m}){ }^{(71)}$.

Durante o fluxo da corrente elétrica, um condutor é percorrido por elétrons. A elevada velocidade de propagação do impulso elétrico permitiria supor que o fluxo é fácil. No entanto, a corrente elétrica precisa superar resistências no percurso através do material condutor ${ }^{(71)}$.

Esta resistência varia de acordo com o material e recebe o nome de resistência do condutor elétrico, podendo ser traduzida em números por meio de experiências. A resistência relativa a $1 \mathrm{~m}$ de comprimento e $1 \mathrm{~mm}^{2}$ de secção transversal de um determinado condutor chama-se "resistência específica" ou "resistividade". A unidade de medida da resistência é o Ohm $(\Omega)$, assim 
denominado em homenagem ao físico alemão GEORG SIMON OHM (71), descobridor do princípio básico da teoria da eletricidade em 1849 (relação entre tensão, intensidade de corrente e resistência de um circuito elétrico). De acordo com as experiências do físico, $1 \mathrm{Ohm}$ é a resistência oferecida por um fio de mercúrio de $1 \mathrm{~mm}^{2}$ de seção transversal e $106,3 \mathrm{~cm}$ de comprimento ${ }^{(71)}$.

Para se calcular a resistência de um determinado material a partir de sua resistividade ou resistência específica utiliza-se a equação $6^{(71)}$ :

$$
R=\rho . I / A
$$

Onde:

$R=$ resistência elétrica do material $(\Omega)$;

$\rho=$ resistividade ou resistência específica do material $\left(\Omega^{*} \mathrm{~cm}\right)$;

$\mathrm{I}=$ comprimento $(\mathrm{cm})$;

$\mathrm{A}=$ área da seção transversal $\left(\mathrm{cm}^{2}\right)$.

Os valores de energia de ativação (energia necessária para que a reação aconteça) podem ser determinados utilizando os coeficientes angulares (b) da curva de Arrhenius juntamente com a equação $7^{\text {(72): }}$

$$
\mathrm{Ea}=\mathrm{b} \cdot \mathrm{k} \cdot 2,3026 \cdot 1000
$$

Onde:

$\mathrm{Ea}=$ energia de ativação (eV);

$\mathrm{b}=$ coeficiente angular da curva de Arrhenius;

$\mathrm{k}=$ constante de Boltzmann $=8,617 \times 10^{-5}(\mathrm{eV} / \mathrm{K})$. 


\section{MATERIAIS E MÉTODOS}

\subsection{Matérias Primas de Partida}

Para a síntese, processamento e caracterização do NSM obtido pela técnica de reação no estado sólido (mistura de sólidos), foram utilizadas as seguintes matérias-primas de partida:

- Carbonato de Neodímio - $\mathrm{Nd}_{2}\left(\mathrm{CO}_{3}\right)_{3}$ - com 98,5 \% de pureza (Vetec);

- Carbonato de Estrôncio - $\mathrm{SrCO}_{3}$ - com 99,9 \% de pureza (Aldrich);

- Carbonato de Manganês - $\mathrm{MnCO}_{3}$ - $\operatorname{com}$ 99,9 \% de pureza (Aldrich);

- Álcool Isopropílico - P.A. (Merck);

- Água Destilada (Laboratórios de Insumos e Reologia - CCTM);

- Água Deionizada (Laboratório de Insumos e Reologia - CCTM).

\subsection{Composição Química e Nomenclatura}

A composição química de cada amostra, assim como a nomenclatura adotada para identificar os materiais obtidos são apresentadas na Tabela 4.1.

Tabela 4.1 - Composição química e nomenclatura adotada para estudo do $\mathrm{Nd}_{1-x} \mathrm{Sr}_{x} \mathrm{MnO}_{3}$.

\begin{tabular}{|c|c|c|c|c|}
\hline $\begin{array}{l}\text { Composição } \\
\text { Química }\end{array}$ & $\begin{array}{c}\text { Composição } \\
\text { de Estrôncio } \\
(\%)\end{array}$ & $\begin{array}{c}\text { Nomenclatura } \\
\text { (Pós) }\end{array}$ & $\begin{array}{c}\text { Temperatura } \\
\text { de Sinterização } \\
\left({ }^{\circ} \mathrm{C}\right)\end{array}$ & $\begin{array}{c}\text { Nomenclatura } \\
\text { (Cerâmicas) }\end{array}$ \\
\hline \multirow{4}{*}{$\mathrm{Nd}_{0,90} \mathrm{Sr}_{0,10} \mathrm{MnO}_{3}$} & \multirow{4}{*}{10} & \multirow{4}{*}{ NSM10 } & 1100 & NSM1011 \\
\hline & & & 1200 & NSM1012 \\
\hline & & & 1300 & NSM1013 \\
\hline & & & 1400 & NSM1014 \\
\hline \multirow{4}{*}{$\mathrm{Nd}_{0,70} \mathrm{Sr}_{0,30} \mathrm{MnO}_{3}$} & \multirow{4}{*}{30} & \multirow{4}{*}{ NSM30 } & 1100 & NSM3011 \\
\hline & & & 1200 & NSM3012 \\
\hline & & & 1300 & NSM3013 \\
\hline & & & 1400 & NSM3014 \\
\hline \multirow{4}{*}{$\mathrm{Nd}_{0,50} \mathrm{Sr}_{0,50} \mathrm{MnO}_{3}$} & \multirow{4}{*}{50} & \multirow{4}{*}{ NSM50 } & 1100 & NSM5011 \\
\hline & & & 1200 & NSM5012 \\
\hline & & & 1300 & NSM5013 \\
\hline & & & 1400 & NSM5014 \\
\hline
\end{tabular}


Para a nomenclatura das amostras em forma de pós, foram adotadas as letras NSM representando o material $\mathrm{Nd}_{1-\mathrm{x}} \mathrm{Sr}_{x} \mathrm{MnO}_{3}$ (Manganito de Neodímio Dopado com Estrôncio) e seguido da quantidade do dopante estrôncio (por exemplo: 10, que representa " $x=0,10$ "; ou seja, $10 \%$ em mol de Sr). Para a nomenclatura das amostras em forma de pastilhas, adotou-se as letras NSM, o número que indica a quantidade de estrôncio e os dois primeiros algarismos da temperatura de sinterização realizada (por exemplo: 11 , que representa $1100^{\circ} \mathrm{C}$ ).

\subsection{Procedimento Experimental}

\subsubsection{Preparação dos pós}

Para a preparação dos pós de NSM foi utilizada a técnica de mistura de sólidos. A Figura 4.1 apresenta um fluxograma detalhado da preparação dos pós e das caracterizações realizadas.

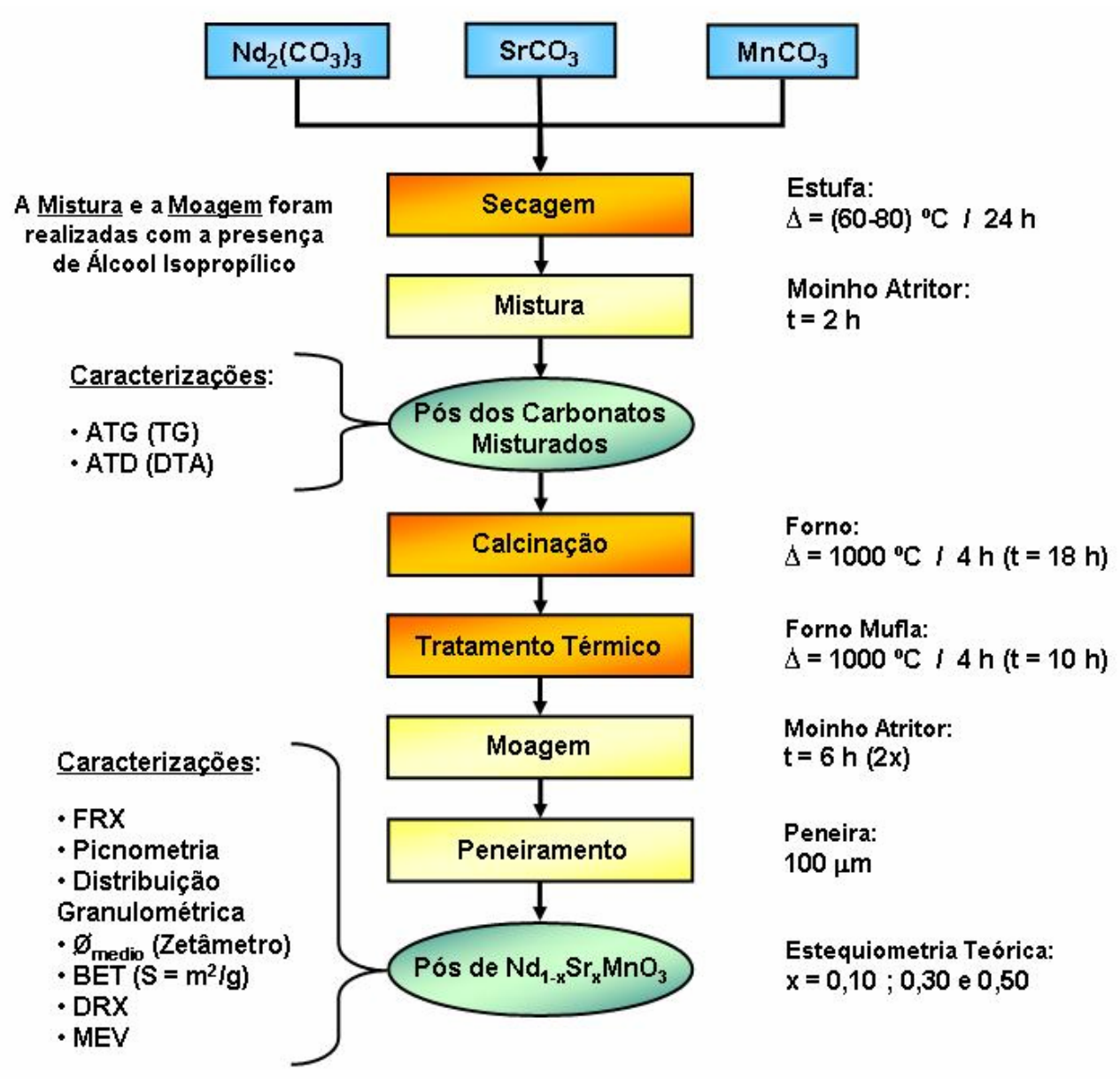

Figura 4.1 - Fluxograma ilustrativo da síntese de pós de NSM. 


\subsubsection{Mistura}

A primeira etapa de síntese do NSM consistiu na secagem em estufa de marca FANEM, modelo $515 A$ por aproximadamente 24 horas e posterior prémistura manual em almofariz dos pós de $\mathrm{Nd}_{2}\left(\mathrm{CO}_{3}\right)_{3}, \mathrm{SrCO}_{3}$ e $\mathrm{MnCO}_{3}$ para cada uma das estequiometrias adotadas. A mistura foi realizada em moinho atritor de marca VARIRED, modelo M3OBF por 2 horas com a presença de álcool isopropílico. A mistura foi adotada com a finalidade de conseguir uma maior homogeneização do material, o que não seria possível com a mesma eficiência em um moinho de bolas ou com mistura manual utilizando um almofariz.

É importante mencionar que foram confeccionados acessórios exclusivos (copo, haste e haletas) para a utilização deste material, evitando assim, a contaminação com outros materiais sintetizados no mesmo moinho. $O$ copo e a haste foram confeccionados em teflon e as haletas em nylon. A contaminação ocasionada pelo desgaste dos acessórios durante as operações do moinho não foram levadas em consideração, pois como são materiais poliméricos, serão extraídos das amostras nos tratamentos térmicos.

Um maior cuidado foi tomado em relação aos corpos de moagem (esferas de moagem) que foram utilizados, pois os mesmos são feitos de zircônia. Neste caso, para evitar ao máximo qualquer tipo de contaminação, as esferas eram lavadas com acetona no ultra-som marca UNIQUE, modelo USC2850.

\subsubsection{Caracterização dos pós após a etapa de mistura}

\subsubsection{Análise térmica gravimétrica e análise térmica diferencial}

O material que contém os carbonatos misturados foi caracterizado por análise térmica gravimétrica (ATG) e por análise térmica diferencial (ATD).

A ATG é utilizada para acompanhar a variação de perda ou ganho de massa, geralmente expressa em porcentagem (\%) ou miligrama (mg) de um determinado material em função da temperatura $\left({ }^{\circ} \mathrm{C}\right)$. Essas variações podem ser positivas, como em processos de oxidação, ou negativas, como na redução e devido a perdas de umidade, decomposição de carbonatos, entre outros ${ }^{(73)}$. 
A ATD é utilizada para acompanhar as transformações que ocorrem em uma determinada substância ou amostra com o aumento de temperatura $\left({ }^{\circ} \mathrm{C}\right)$. Por esta técnica é possível verificar a temperatura em que ocorreram fenômenos como transformações de estrutura, reações que envolvem liberação ou absorção de energia, transformações de fase, mudanças de estado físico, desprendimento de gases e aparecimento de fases líquidas ${ }^{(74)}$.

As duas análises foram realizadas simultaneamente no mesmo equipamento. As transformações endotérmicas ou exotérmicas são registradas como deflexões em sentidos opostos na curva. As transformações endotérmicas são, por exemplo, as reações de decomposição, dissociação gasosa, entre outras; e as exotérmicas são, por exemplo, as oxidações, cristalizações, transformações cristalinas, entre outras ${ }^{(73,74)}$.

As análises dos carbonatos foram obtidas em um analisador térmico marca SETARAM INSTRUMENTATION, modelo LABSYS S60/51935. O material de referência utilizado foi alumina, com taxa de aquecimento de $10^{\circ} \mathrm{C} / \mathrm{min}$ e temperatura ambiente até $1300^{\circ} \mathrm{C}$ com fluxo de ar sintético.

\subsubsection{Síntese dos pós de $\mathrm{Nd}_{1-x} \mathrm{Sr}_{x} \mathrm{MnO}_{3}$}

\subsubsection{Calcinação}

Após a etapa de mistura, os pós dos respectivos carbonatos misturados foram calcinados a $1000^{\circ} \mathrm{C}$ durante 4 horas ${ }^{(49)}$ (Figura 4.2).

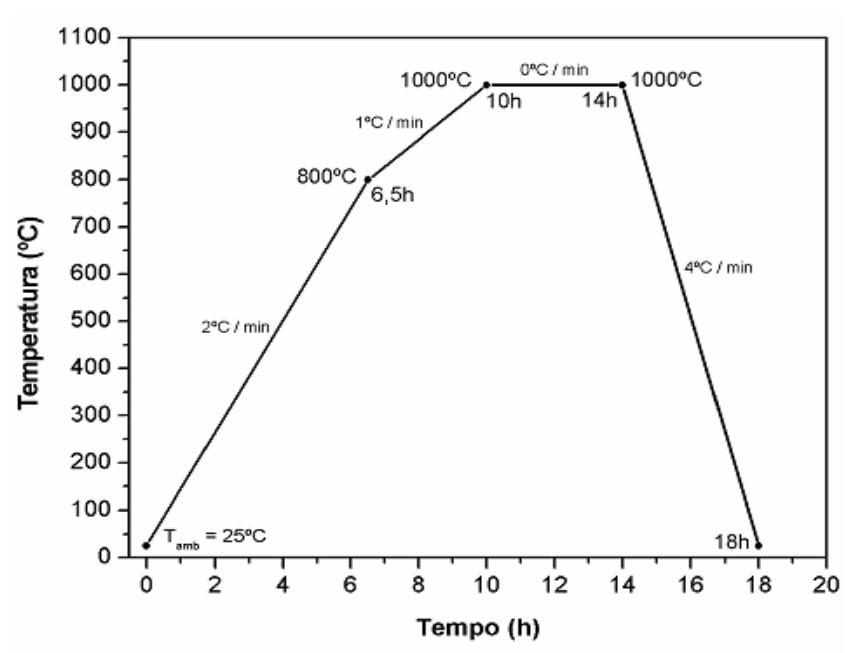

Figura 4.2 - Gráfico ilustrativo da etapa de calcinação. 
O objetivo da calcinação a esta temperatura e durante este tempo é sintetizar o material NSM. Um forno elétrico tipo caixa de marca LINDBERG, modelo BLUE M com controle de temperatura e taxa de aquecimento foi utilizado.

\subsubsection{Tratamento térmico}

Para diminuir o teor de carbono (\%C em massa) encontrado em todas as amostras após a calcinação, foi realizado um tratamento térmico em forno elétrico mufla marca QUIMIS, modelo Q-318M24 a $1000{ }^{\circ} \mathrm{C}$ durante 4 horas ${ }^{(49)}$.

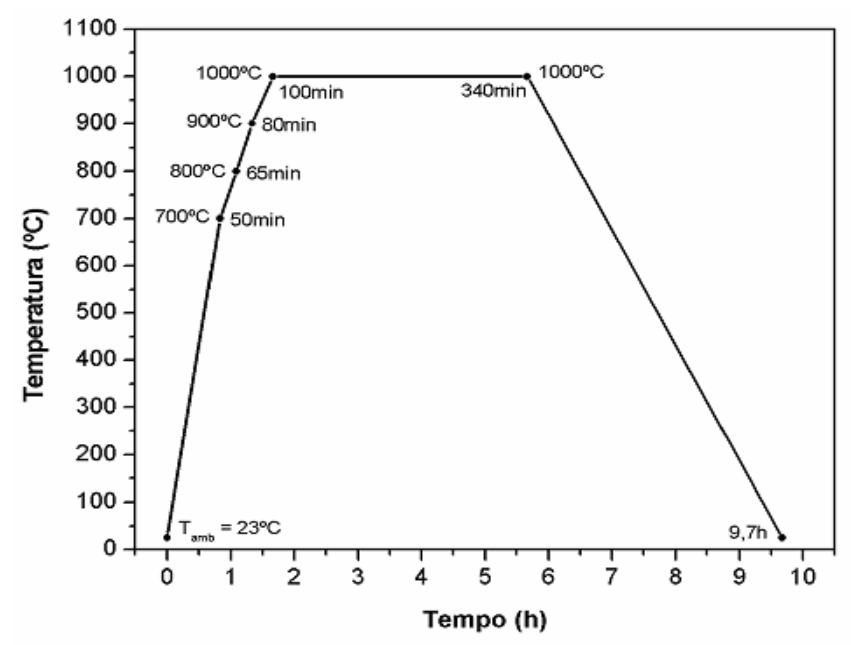

Figura 4.3 - Gráfico ilustrativo da etapa de tratamento térmico.

\subsubsection{Moagem}

Com o material sintetizado, foi realizada a etapa de moagem utilizando moinho atritor de marca VARIRED, modelo $M 30 B F$ para a cominuição das partículas. O tempo de 12 horas dividido em duas vezes de 6 horas foi definido de acordo com a literatura ${ }^{(7,8)}$.

\subsubsection{Peneiramento}

Em seguida foram realizadas etapas de peneiramento com a finalidade de desaglomerar as partículas dos pós de NSM para a realização de caracterizações físicas, químicas e microestruturais. A malha utilizada para o peneiramento possui aberturas de $100 \mu \mathrm{m}$. 


\subsubsection{Caracterização dos pós de $\mathrm{Nd}_{1-x} \mathrm{Sr}_{x} \mathrm{MnO}_{3}$}

As caracterizações físicas, químicas e microestruturais dos pós de NSM foram realizadas por diversas técnicas de análise.

\subsubsection{Cromatografia de absorção gasosa}

$\mathrm{Na}$ análise por cromatografia de absorção gasosa, o teor de carbono residual (pode ser expresso em \% em massa ou ppm) presente nos materiais, é determinado utilizando o princípio de absorção por radiação infravermelha. Este princípio realiza a extração dos gases do material sob atmosfera de oxigênio, na forma de $\mathrm{CO}$ e $\mathrm{CO}_{2}$ em forno de radiofreqüência, além de realizar a identificação analítica destes gases em uma célula utilizando infravermelho ${ }^{(75,76)}$.

Nesta análise, são utilizados aceleradores para auxiliar a combustão do material no forno de indução, diminuindo o seu ponto de fusão. $O$ teor de carbono é analisado na faixa de ppm, tendo um limite mínimo de deteç̧ão de 0,5 ppm e um desvio padrão em torno de $10 \%{ }^{(75,76)}$.

Os teores de carbono residuais dos pós das amostras de NSM foram obtidos em um cromatógrafo marca $L E C O$, modelo CS400. O cadinho utilizado para queima do material é constituído de alumina e o acelerador fundente é uma mistura de tungstênio (W) e estanho (Sn) ${ }^{(75,76)}$.

\subsubsection{Espectrometria de fluorescência de raios $\mathrm{X}$ por energia dispersiva}

A espectrometria de fluorescência de raios $X$ ( $F R X)$ é realizada com um espectrômetro que utiliza sinais de raios $X$ para excitar um determinado material. Os elementos químicos presentes nesse material emitem seus raios $X$ característicos, que são detectados pelo equipamento e são determinados qualitativamente e/ou quantitativamente ${ }^{(76,77)}$.

A FRX por energia dispersiva (EDS) detecta os raios $X$ através de um semicondutor, o qual permite análises simultâneas, possibilitando uma análise extremamente rápida, mesmo na faixa de ppm. As análises ao ar são possíveis, devido à pequena distância entre o material e o semicondutor ${ }^{(76,77)}$. 
As composições químicas dos pós de NSM foram obtidas em um espectrômetro marca SHIMADZU, modelo EDX900HS. As amostras foram condicionadas em porta amostra de teflon na presença vácuo.

\subsubsection{Picnometria de gás hélio}

A análise por picnometria de gás hélio consiste na obtenção do volume de um sólido através da redução do fluxo de gás em uma câmara de medida, causada pela presença do próprio sólido. O gás hélio $(\mathrm{He})$ penetra nas superfícies irregulares e em seus poros, onde o volume obtido e a massa determinada permitem o cálculo da densidade real $\left(\mathrm{g} / \mathrm{cm}^{3}\right)$ de um determinado material ${ }^{(78)}$.

As densidades reais determinadas por picnometria para os pós de NSM foram obtidas em um picnômetro marca MICROMERITICS, modelo 1330.

\subsubsection{Análise granulométrica por espalhamento de feixes de laser}

A análise granulométrica por espalhamento laser permite determinar os diâmetros médios de partículas, expresso geralmente em mícron $(\mu \mathrm{m})$, utilizando os fenômenos de difração e difusão de um feixe de laser ao atravessar o meio onde se encontram as partículas em suspensão ${ }^{(79,80)}$.

Esta técnica se aplica a pós que se dispersam facilmente em água ou álcool, além de suspensões e emulsões. Quando a partícula atinge o feixe de luz, essa luz pode ser transmitida, adsorvida e/ou espalhada. A luz espalhada é afetada pelo índice de refração relativo ao meio de suspensão das partículas, pelo seu comprimento de onda e pelo tamanho e forma das partículas ${ }^{(79,80)}$.

Na câmara de análise, os detectores medem a intensidade e o ângulo da luz espalhada, onde o sinal é convertido em informações relacionadas à distribuição de tamanho médio de partículas ${ }^{(80,81)}$. Dependendo do tamanho das partículas, duas teorias são bastante utilizadas: a teoria de Fraunhöffer (teoria da difração), quanto menor o tamanho da partícula, maior o ângulo de difração de um feixe luminoso que atravessa uma população de partículas e a teoria de Mie (teoria da difração-difusão), que é válida para partículas bastante maiores do que o comprimento de onda da luz utilizada ${ }^{(81)}$. 
As distribuições granulométricas das partículas das amostras de NSM foram obtidas em um granulômetro marca CILAS, modelo 1064. As amostras foram dispersas em ultra-som durante 3 minutos. Na dispersão foi utilizada água destilada como solvente e um dispersante.

\subsubsection{Análise de diâmetro médio utilizando o zetâmetro}

O diâmetro médio, em micrometro $(\mu \mathrm{m})$ também foi determinado utilizando um analisador de potencial zeta marca BROOKHAVEN INSTRUMENTS CORPORATION, modelo ZETAPALS ${ }^{(82)}$. Este equipamento determina através da dispersão de partículas, utilizando feixes de laser, o diâmetro médio de partículas e apresenta os resultados em um software denominado Particle Sizing.

\subsubsection{6. Área de superfície específica}

A área de superfície específica $\left(\mathrm{m}^{2} / \mathrm{g}\right)$, teoria proposta por BRUNAUER, EMMETT e TELLER, conhecida como BET, descreve a adsorção física dos gases em superfícies sólidas ${ }^{(83)}$. O aumento da adsorção física dos gases nos sólidos ocorre com a diminuição da temperatura e com o aumento da pressão. As amostras são aquecidas para eliminação da umidade e posteriormente resfriadas em nitrogênio líquido. Em seguida, as amostras são alimentadas pelo gás a ser adsorvido a uma temperatura fixa. Os dados das curvas de adsorção são calculados para a determinação da área de superfície específica ${ }^{(84,85)}$.

A partir do valor da área de superfície específica, é possível determinar o tamanho médio das partículas do material utilizando a equação $8{ }^{(86)}$ que considera a morfologia das partículas esféricas.

$$
D=6 /\left(\rho_{t} \cdot S\right)
$$

Onde:

$$
\begin{aligned}
& D=\text { diâmetro médio da partícula }(\mu \mathrm{m}) ; \\
& \rho_{\mathrm{t}}=\text { densidade teórica do material }\left(\mathrm{g} / \mathrm{cm}^{3}\right) ; \\
& S=\text { área específica da partícula }\left(\mathrm{m}^{2} / \mathrm{g}\right) .
\end{aligned}
$$


As áreas de superfície específica para os pós das amostras de NSM foram obtidas em um analisador marca MICROMERITICS, modelo ASAP2010. As amostras foram aquecidas à temperatura de $300^{\circ} \mathrm{C}$ para eliminação da umidade e resfriada em nitrogênio líquido, que participa da análise como gás de adsorção.

\subsubsection{Difratometria de raios $X$}

Através da análise por difratometria de raios $X(D R X)$ realizaram-se as identificações das fases cristalinas, as verificações das estruturas cristalinas e dos parâmetros de rede das células unitárias ${ }^{(73,87)}$. Esta técnica detecta o feixe de raios $X$ difratado após a incidência sobre o material. $O$ feixe difratado pelos átomos no reticulado cristalino e nos planos cristalográficos deve seguir a Lei de Bragg, que é representada pela equação $9{ }^{(73,87)}$.

$$
\mathrm{n} \cdot \lambda=2 \cdot d \cdot \operatorname{sen} \theta
$$

Onde:

$$
\begin{aligned}
& n=\text { número inteiro de comprimento de onda; } \\
& \lambda=\text { comprimento de onda da radiação incidente; } \\
& d=\text { distância interplanar entre dois planos adjacentes; } \\
& \theta=\text { ângulo de incidência da radiação. }
\end{aligned}
$$

Os difratogramas dos pós de NSM foram obtidos através de um difratômetro marca RIGAKU, modelo MULTIFLEX. As amostras foram analisadas com uma radiação CuKa, na faixa angular de $2 \theta$ entre 20 e $80^{\circ}$ a um passo de varredura de $0,02^{\circ} \mathrm{e}$ tempo de permanência em torno de 1 a 2 horas.

\subsubsection{Microscopia eletrônica de varredura}

O princípio de funcionamento do microscópio eletrônico de varredura (MEV) consiste na emissão de um feixe de elétrons, provocando uma diferença de potencial que acelera os elétrons e conseqüentemente aquece o filamento. A correção do percurso dos feixes de elétrons é realizada pelas lentes 
condensadoras que "varrem" a superfície da amostra contida em uma câmara contendo vácuo. A interação dos feixes de elétrons com a superfície do material promove a emissão de elétrons secundários, retroespalhados, raios $X$ característicos e fótons. Os elétrons secundários e os retroespalhados são os sinais mais utilizados para a formação de imagem ${ }^{(88,89)}$.

O MEV é um equipamento capaz de produzir imagens de alta resolução, da ordem de até 300 mil vezes, permitindo obter resultados tanto microestruturalmente como quimicamente ${ }^{(88,89)}$. As imagens observadas dos pós de NSM foram obtidas pelo MEV marca PHILIPS, modelo XL30.

Para a preparação dos pós de NSM, inicialmente foi feita uma dispersão do material em uma pequena quantidade de acetona e utilizando o ultra-som para formar uma suspensão. Uma pequena alíquota foi retirada dessa suspensão e depositada sobre a superfície do porta amostra de alumínio. Após a secagem da suspensão, foi aplicado um recobrimento de ouro por sputtering e levado ao MEV para observação da distribuição e da forma dos aglomerados.

\subsubsection{Processamento cerâmico}

Após a obtenção do material na forma de pós, realizaram-se etapas de processamento (Figura 4.4) do mesmo para a confecção de pastilhas cerâmicas.

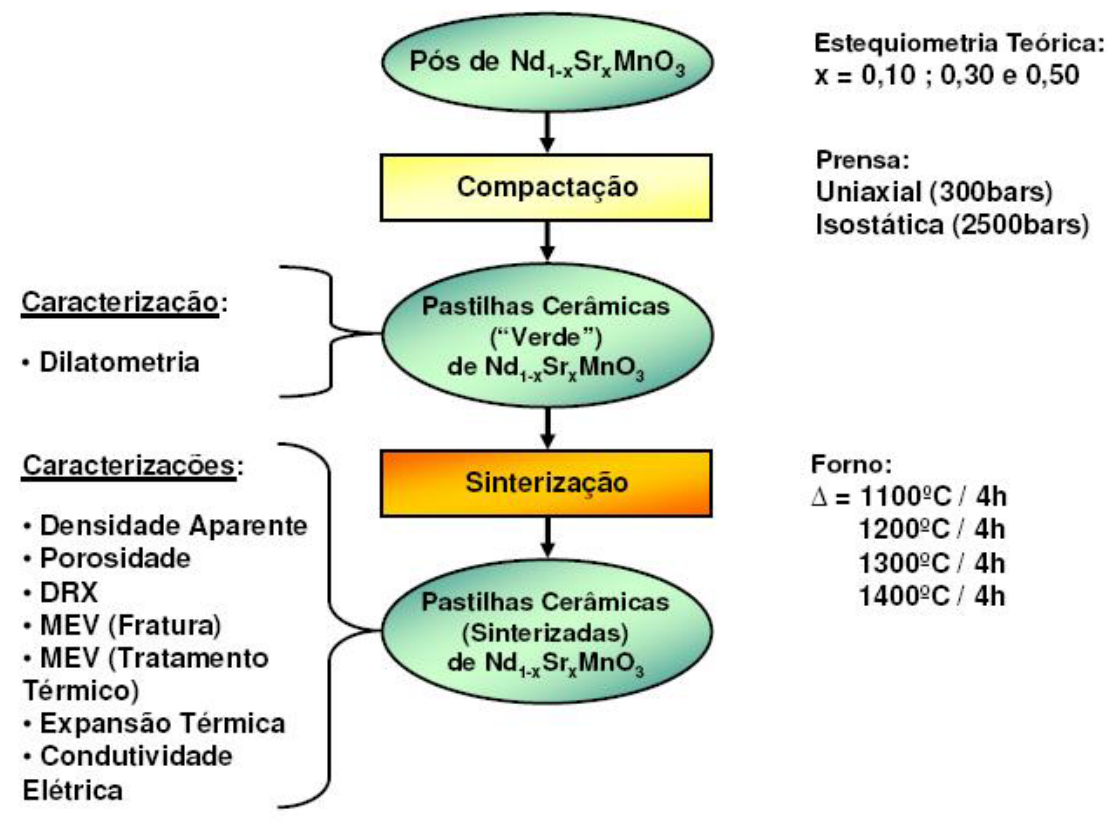

Figura 4.4 - Fluxograma ilustrativo para preparação das pastilhas cerâmicas de NSM. 
As pastilhas cerâmicas, com aproximadamente $10 \mathrm{~mm}$ de diâmetro e entre um e dois milímetros de espessura, foram posteriormente caracterizadas por análises físicas e microestruturais.

\subsubsection{Compactação}

Os pós de NSM foram conformados, na forma de pastilhas cilíndricas por prensagem uniaxial (30 MPa) e posterior prensagem isostática (250 MPa).

Para a primeira etapa de conformação por prensagem uniaxial, foi utilizada uma matriz de aço especialmente fabricada para esta finalidade e estearato de zinco - $\mathrm{Zn}\left(\mathrm{C}_{18} \mathrm{H}_{35} \mathrm{O}_{2}\right)_{2}$ como lubrificante para a matriz e seus respectivos punções. Uma prensa uniaxial de marca SOMAR, modelo 01098 foi utilizada para a realização desta etapa.

Para a segunda etapa de conformação, as pastilhas foram envolvidas em dedeiras de látex. Com a utilização de uma bomba de vácuo marca QUIMIS, modelo 355B2 foi realizado vácuo em cada amostra. Para a prensagem das amostras utilizou-se uma prensa isostática de marca ENERPAC, modelo T6010L.

A prensagem isostática foi realizada devido às amostras de NSM serem extremamente frágeis, pois a prensagem uniaxial não consegue fornecer uma resistência mecânica que permita manipular as pastilhas "a verde" para a realização de medidas de massa $(\mathrm{g})$, diâmetro $(\mathrm{mm})$ e espessura $(\mathrm{mm})$.

Para as medidas de diâmetro e espessura foi utilizado um micrômetro de marca MITUTOYO e para as pesagens das massas utilizou-se uma balança analítica de marca METTLER TOLEDO, modelo AG204.

\subsubsection{Sinterização}

Continuando a etapa de processamento, foram realizados tratamentos térmicos de sinterização a temperaturas de 1100, 1200, 1300 e $1400{ }^{\circ} \mathrm{C}$ durante aproximadamente 4 horas ${ }^{(49)}$ em forno elétrico tipo caixa de marca LINDBERG, modelo BLUE $M$, com velocidade de aquecimento de $20{ }^{\circ} \mathrm{C} / \mathrm{min}$ até $850{ }^{\circ} \mathrm{C}$, $2{ }^{\circ} \mathrm{C} / \mathrm{min}$ até a temperatura de sinterização desejada e $10^{\circ} \mathrm{C} / \mathrm{min}$ de velocidade de resfriamento ${ }^{(91)}$. Essas condições (Figura 4.5) foram adotadas de acordo com os resultados da dilatometria e de trabalhos divulgados na literatura ${ }^{(8,13,15,49)}$. 


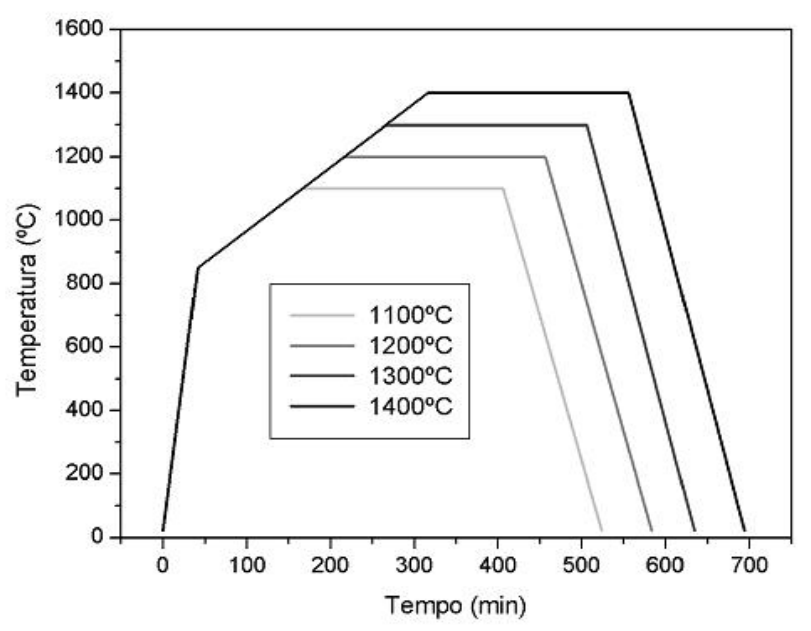

Figura 4.5 - Fluxograma ilustrativo da etapa de sinterização.

Alguns autores verificaram que temperaturas de sinterização entre 1100 e $1400^{\circ} \mathrm{C}$, variando o tempo de 2 a 24 horas, influenciam a densidade e a porosidade do material sinterizado ${ }^{(15,49,93,94)}$. Abaixo de $1100{ }^{\circ} \mathrm{C}$ as pastilhas ficam frágeis e acima de $1400{ }^{\circ} \mathrm{C}$ o material se encontra muito denso e não aplicável como eletrodo catódico ${ }^{(93,94)}$.

Após as sinterizações e medidas de massa, espessura, diâmetro e densidade hidrostática, parte das pastilhas foram para as etapas de caracterizações físicas e microestruturais e, a outra parte, para as etapas de fratura, embutimento, lixamento, polimento e ataque térmico (choque térmico).

\subsubsection{Preparação das amostras sinterizadas}

\subsection{Corte das amostras sinterizadas}

Algumas pastilhas cerâmicas foram cortadas para visualização por MEV do aspecto da superfície fraturada e presença de porosidade.

\subsection{Embutimento}

As amostras fraturadas foram embutidas a frio em resina polimérica para a realização de etapas de lixamento e polimento com a finalidade de preparar a superfície da amostra para visualização por MEV após a realização de um tratamento térmico. 


\subsection{Lixamento}

O lixamento foi realizado com a utilização de quatro lixas específicas $(220,400,600$ e 1500) de marca NORTON. As amostras foram lixadas em todas as lixas, começando pela lixa de número 220 e terminando na lixa 1500. Para esta etapa foi utilizada uma lixadeira manual de marca FORTEL, modelo PLF.

\subsection{Polimento}

O polimento foi realizado com a utilização de dois panos magnéticos de marca PRESI, modelo MAGNWF. Para esta etapa, utilizou-se glicerina para umidificação dos panos e duas pastas de diamante (6 $\mu \mathrm{m}$ e $1 \mu \mathrm{m})$. O polimento foi realizado em uma politriz automática de marca MECAPOL, modelo P220U.

Após o polimento, as amostras foram retiradas das resinas de embutimento utilizando uma chapa aquecedora marca QUIMIS, modelo 2612.

\subsection{Tratamento térmico para revelação dos grãos}

Um tratamento térmico foi adotado para identificar os grãos presentes nas superfícies que foram lixadas e polidas. A operação consistiu em atacar termicamente as amostras a uma temperatura abaixo do valor correspondente a temperatura de sinterização em que a amostra foi submetida. Este tratamento térmico é válido para garantir a revelação dos grãos e não alterar as condições microestruturais determinadas pelo processo de sinterização. Os tempos de ataque térmico variam de acordo com a literatura ${ }^{(95,96)}$. Com isso, adotaram-se tempos de 20, 40 e 60 min.

Para a realização do ataque térmico foi utilizado um forno elétrico mufla de marca QUIMIS, modelo Q-318M24. As amostras foram colocadas somente quando o forno atingia a temperatura desejada, deixadas durante o tempo determinado e retiradas em seguida para a temperatura ambiente.

\subsubsection{Caracterização das cerâmicas a verde}

Para determinar as temperaturas de sinterização, foi realizada dilatometria em algumas pastilhas a verde. 


\subsubsection{Dilatometria}

A dilatometria mede as variações das dimensões de uma determinada amostra em função da temperatura, ou seja, mede a sua expansão e retração térmica. As mudanças dimensionais são ocasionadas devido ao aumento na amplitude vibracional entre os átomos da amostra na temperatura analisada. $\mathrm{A}$ variação dimensional é determinada pela força de ligação e pelo arranjo atômico do material, sendo que o aumento das forças de ligação aumenta relativamente à temperatura de fusão e reduz o coeficiente de expansão térmica ${ }^{(70,73)}$.

Para a dilatometria, foram utilizadas amostras cilíndricas conformadas por prensagem uniaxial, com aproximadamente $6 \mathrm{~mm}$ de diâmetro e $8 \mathrm{~mm}$ de comprimento. Os resultados foram obtidos em um dilatômetro de marca SETARAM INSTRUMENTATION, modelo LABSYS S60/51935, com taxa de aquecimento de $5^{\circ} \mathrm{C} / \mathrm{min}$ até $1400^{\circ} \mathrm{C}$ em atmosfera de ar sintético.

\subsubsection{Caracterização das cerâmicas sinterizadas}

As caracterizações das cerâmicas sinterizadas de NSM foram realizadas por análises físicas e microestruturais.

\subsubsection{Método de Determinação da Densidade geométrica a verde}

Após a etapa de conformação e antes da sinterização, as amostras em forma de pastilhas cilíndricas foram submetidas a medidas de massa, diâmetro e espessura para o cálculo da densidade geométrica (Equação 10) ${ }^{(79)}$ :

$$
\rho_{g}=m / V_{c}=m /\left(\pi \cdot r^{2} \cdot h\right)
$$

Onde:

$\rho_{\mathrm{g}}=$ densidade geométrica $\left(\mathrm{g} / \mathrm{cm}^{3}\right)$;

$\mathrm{m}=$ massa $(\mathrm{g})$;

Vc = volume da pastilha cilíndrica $\left(\mathrm{cm}^{3}\right)$;

$\mathrm{r}=$ raio do cilindro $(\mathrm{cm})$ e $\mathrm{h}=$ altura do cilindro $(\mathrm{cm})$. 


\subsubsection{Método de Determinação da Densidade geométrica dos sinterizados}

Após a sinterização, as amostras em forma de pastilhas cilíndricas foram submetidas novamente às mesmas medidas para o cálculo da densidade geométrica dos sinterizados. O procedimento é idêntico ao item anterior.

\subsubsection{Método de Determinação da Densidade aparente dos sinterizados}

A densidade aparente (hidrostática) é obtida pelo princípio de Arquimedes e mostra que um corpo imerso em um fluido sofre a ação de duas forças, peso e empuxo, cuja intensidade do empuxo é igual e contrária ao peso do fluido deslocado pelo corpo ${ }^{(79)}$, como mostra a equação 11 :

$$
\rho_{A}=\left(M_{s} \cdot \rho_{L}\right) /\left(M_{u}-M_{i}\right)
$$

Onde:

$$
\begin{aligned}
& \rho_{\mathrm{A}}=\text { densidade aparente }\left(\mathrm{g} / \mathrm{cm}^{3}\right) ; \\
& M_{\mathrm{S}}=\text { massa seca }(\mathrm{g}) ; \\
& \rho_{\mathrm{L}}=\text { densidade do líquido na temperatura da medida }\left(\mathrm{g} / \mathrm{cm}^{3}\right) \\
& M_{\mathrm{U}}=\text { massa úmida }(\mathrm{g}) ; \\
& M_{\mathrm{i}}=\text { massa imersa }(\mathrm{g}) .
\end{aligned}
$$

Por este método, o material sinterizado é imerso em um líquido fervente durante um tempo suficiente para que o mesmo penetre nas superfícies irregulares e regiões com a presença de porosidade aberta.

Antes das medidas, as amostras foram colocadas na presença de água destilada em ebulição durante 2 horas e resfriadas a temperatura ambiente. Em seguida, foram medidas as massas úmidas e imersas; e a temperatura da água destilada. A medida da massa seca é realizada após secagem em estufa marca LINDBERG / BLUE M, modelo M01490C-1 a $100^{\circ} \mathrm{C}$ e após serem resfriadas em um dessecador.

As densidades aparentes para as cerâmicas de NSM foram obtidas em uma balança marca METTLER TOLEDO, modelo AG204 com precisão de $10^{-4} \mathrm{~g}$. 


\subsubsection{Método de Determinação da Densidade teórica e da porosidade}

A densidade teórica foi obtida no banco de dados JCPDS de DRX e a porosidade de todas as amostras foi calculada através da equação 12 :

$$
P=\left(\rho_{t}-\rho_{A}\right) / \rho_{t} \cdot 100
$$

Onde:

$$
\begin{aligned}
& P=\text { porosidade }(\%) \\
& \rho_{t}=\text { densidade teórica }\left(\mathrm{g} / \mathrm{cm}^{3}\right) \\
& \rho_{A}=\text { densidade aparente }\left(\mathrm{g} / \mathrm{cm}^{3}\right) .
\end{aligned}
$$

\subsubsection{Difratometria de raios $X$}

As pastilhas cerâmicas sinterizadas de NSM foram analisadas por DRX. O procedimento é o mesmo das amostras em forma de pós. A única diferença está no preparo da amostra, que neste caso é pastilha, onde a cola de prata é colocada em volta da pastilha e o ouro na superfície de visualização.

\subsubsection{Microscopia eletrônica de varredura}

Para a avaliação das superfícies fraturadas e das superfícies fraturadas e atacadas termicamente, as pastilhas foram fixas com fita adesiva e com cola de prata em portas amostras de alumínio e levadas ao MEV para observação da superfície quanto à porosidade (no caso das fraturadas) e quanto à forma, distribuição e tamanho médio de grãos (no caso das fraturadas e atacadas termicamente). O recobrimento com uma fina camada de ouro, por meio de um sputter coater, marca $S C D$, modelo 50 foi também utilizado nas pastilhas cerâmicas, antes de serem analisadas no MEV.

As imagens observadas das pastilhas cerâmicas fraturadas de NSM foram obtidas pelo MEV marca PHILIPS, modelo XL30 localizado no CCTM dentro do IPEN e as imagens das pastilhas tratadas termicamente foram obtidas pelo MEV marca JEOL, modelo JSM-5900LV localizado no Laboratório Nacional de Luz Síncrotron (LNLS) em Campinas. 


\subsubsection{Expansão térmica}

A expansão térmica mede as variações das dimensões de uma determinada amostra em função da temperatura, ou seja, mede a sua expansão e retração térmica. O Procedimento é idêntico à etapa de dilatometria.

Para esta análise, foram utilizadas amostras cilíndricas conformadas por prensagem uniaxial, com aproximadamente $6 \mathrm{~mm}$ de diâmetro, $8 \mathrm{~mm}$ de comprimento e sinterizadas a 1100 e $1200{ }^{\circ} \mathrm{C}$. Os resultados foram obtidos em um dilatômetro marca SETARAM INSTRUMENTATION, modelo LABSYS $S 60 / 51935$, com taxa de $10^{\circ} \mathrm{C} / \mathrm{min}$ até $1000^{\circ} \mathrm{C}$ em atmosfera de ar sintético.

\subsubsection{Condutividade elétrica}

A análise de condutividade elétrica foi realizada nas mostras de NSM que foram sinterizadas a $1200^{\circ} \mathrm{C}$.

Para a realização desta análise, algumas amostras em forma de pastilhas cilíndricas de $10 \mathrm{~mm}$ de diâmetro e $2 \mathrm{~mm}$ de espessura foram cortadas em uma máquina de corte marca BUEHLER, modelo ISOMET até as dimensões desejadas (aproximadamente $2 \times 2 \times 8 \mathrm{~mm}$ ). Em seguida foram medidas a área da seção transversal $\left(\mathrm{mm}^{2}\right)$ de todas as amostras para posterior cálculos da resistividade elétrica e condutividade elétrica.

A próxima etapa consistiu em colocar quatro contatos de tinta de prata, um paralelo ao outro e separados entre si por uma distância de aproximadamente $2 \mathrm{~mm}$, em uma das superfícies de cada amostra e posterior realização de um ataque térmico a $500{ }^{\circ} \mathrm{C}$ durante aproximadamente 1 hora em forno tubular de marca ELETROTÉRMICA, modelo TB4120.

Após a preparação, as amostras foram verificadas com um voltímetro quanto à qualidade dos contatos de prata colocados, ou seja, se existe a passagem de corrente elétrica e se os contatos estão adequados para a medição durante a operação dentro do forno termoelétrico marca LINDBERG BLUE.

Após a realização da análise, foram calculadas as resistências elétricas $(\Omega)$, a resistividade elétrica $(\Omega \mathrm{cm})$ e a condutividade elétrica $\left(\Omega^{-1} \mathrm{~cm}^{-1}\right)$. 


\section{RESULTADOS E DISCUSSÃO}

Neste capítulo, dividido em quatro partes, são discutidos os principais resultados obtidos para o estudo do NSM. A primeira parte apresenta um estudo de síntese, desde a decomposição dos seus precursores, até a formação do material desejado. A segunda apresenta as caracterizações químicas, físicas e microestruturais do material em forma de pó. A terceira apresenta um estudo de processo para as condições de fabricação do material cerâmico em forma de pastilhas cilíndricas. A quarta e última, apresenta as caracterizações físicas e microestruturais dessas cerâmicas para aplicação como catodo em ITSOFCs.

\subsection{Estudo de Síntese}

\subsubsection{Decomposição dos precursores}

Primeiramente partiu-se com os carbonatos das amostras $\mathrm{Nd}_{0,90} \mathrm{Sr}_{0,10} \mathrm{MnO}_{3} \quad(\mathrm{NSM} 10), \quad \mathrm{Nd}_{0,70} \mathrm{Sr}_{0,30} \mathrm{MnO}_{3} \quad(\mathrm{NSM} 30)$ e $\quad \mathrm{Nd}_{0,50} \mathrm{Sr}_{0,50} \mathrm{MnO}_{3}$ (NSM50) previamente misturados e ainda não sintetizados. As curvas termogravimétricas obtidas são apresentadas na Figura 5.1 (curvas coloridas), e permitem diferenciar três etapas distintas de decomposição e transformações de seus elementos químicos para temperaturas de até $1300^{\circ} \mathrm{C}$.

Estas etapas de decomposição e transformações para a sintetização do material desejado referem-se a:

- Entre 100 e $400{ }^{\circ} \mathrm{C}$ ocorre uma relativa perda de massa, que corresponde à perda da água de hidratação presente no material;

- Entre 400 e $550{ }^{\circ} \mathrm{C}$ ocorre decomposição dos carbonatos formando CO, $\mathrm{CO}_{2}$ e carbonatos intermediários, ocorrendo liberação de gases;

- Entre 550 e $800{ }^{\circ} \mathrm{C}$ ocorre uma relativa decomposição dos carbonatos intermediários a um produto final estável de NSM. Nesta etapa, ocorre a liberação dos gases $\mathrm{CO}$ e $\mathrm{CO}_{2}$; 
- A partir de $700{ }^{\circ} \mathrm{C}$ para as amostras NSM10 e NSM30 e, $800{ }^{\circ} \mathrm{C}$ para a amostra NSM50 ocorre à formação dos materiais desejados;

- Acima de $800^{\circ} \mathrm{C}$, os compostos mostraram-se estáveis.

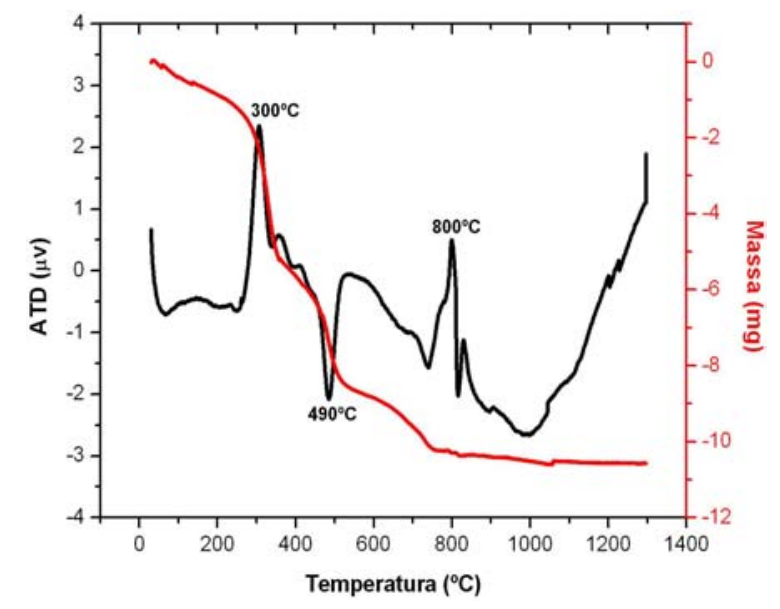

(a)

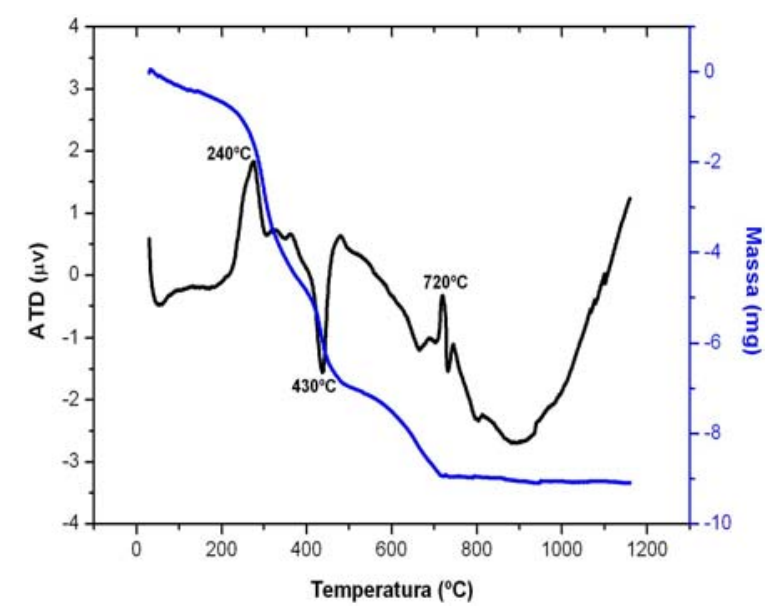

(b)

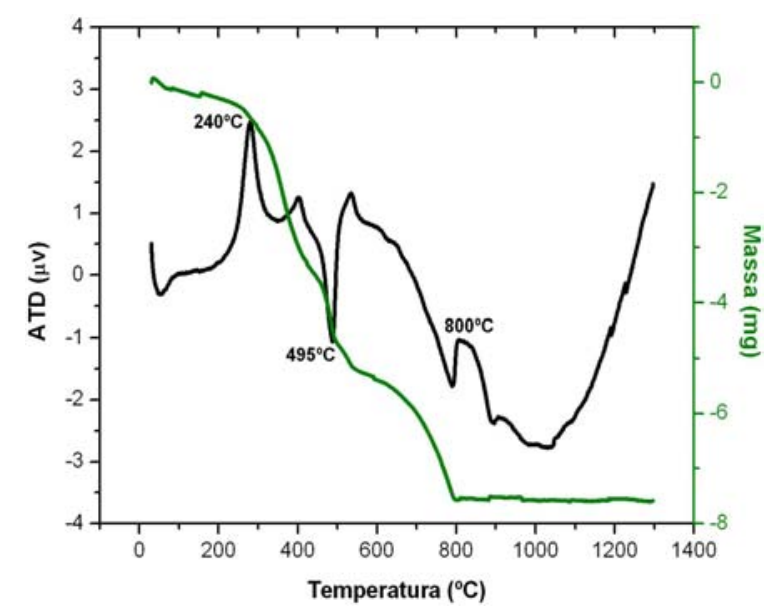

(c)

Figura 5.1 - Resultados da ATG/ATD para os pós de NSM10(a), NSM30(b) e NSM50(c).

A perda de massa é mais intensa no intervalo de 100 a $750{ }^{\circ} \mathrm{C}$ para a amostra NSM10. Na transformação dos carbonatos correspondentes, ocorreu uma perda de massa total em torno de 10,50 mg (69,9 \%) em massa, no intervalo entre a temperatura ambiente $\left(25^{\circ} \mathrm{C}\right)$ e $750^{\circ} \mathrm{C}$. A análise dos resultados é similar para as amostras NSM30 e NSM50. A Tabela 5.1 apresenta os resultados das perdas de massa (expressa em $\mathrm{mg}$ ) total e também para cada intervalo de temperatura (expressa em ${ }^{\circ} \mathrm{C}$ ) dos três materiais em estudo. 
Tabela 5.1 - Perda de massa durante a ATG para as amostras de NSM.

\begin{tabular}{|c|c|c|c|c|c|}
\hline \multirow{3}{*}{ Amostra } & \multirow{3}{*}{$\begin{array}{c}\text { Intervalo de } \\
\text { Temperatura }\left({ }^{\circ} \mathrm{C}\right)\end{array}$} & \multicolumn{4}{|c|}{ Perda de Massa } \\
\hline & & \multicolumn{2}{|c|}{$(\mathrm{mg})$} & \multicolumn{2}{|c|}{ (\% em massa) } \\
\hline & & Intervalo & Total & Intervalo & Total \\
\hline \multirow{3}{*}{ NSM10 } & 25 a 350 & 5,00 & \multirow{3}{*}{10,50} & 33,3 & \multirow{3}{*}{69,9} \\
\hline & 350 a 550 & 3,50 & & 23,3 & \\
\hline & 550 a 750 & 2,00 & & 13,3 & \\
\hline \multirow{3}{*}{ NSM30 } & 25 a 350 & 4,00 & \multirow{3}{*}{9,00} & 26,7 & \multirow{3}{*}{60,0} \\
\hline & 350 a 500 & 3,00 & & 20,0 & \\
\hline & 500 a 700 & 2,00 & & 13,3 & \\
\hline \multirow{3}{*}{ NSM50 } & 25 a 400 & 3,00 & \multirow{3}{*}{7,50} & 20,0 & \multirow{3}{*}{50,0} \\
\hline & 400 a 550 & 2,50 & & 16,7 & \\
\hline & 550 a 800 & 2,00 & & 13,3 & \\
\hline
\end{tabular}

A partir das curvas ATD (coloração preta), localizadas também na Figura 5.1, verificou-se que até 240 ou $300{ }^{\circ} \mathrm{C}$ existe a ocorrência de um pico endotérmico, que deve estar relacionado com o calor necessário para a reação de vaporização da água de cristalização. À medida que continua o aquecimento, são encontrados mais dois picos endotérmicos entre 400 e $500{ }^{\circ} \mathrm{C}$ e também entre 700 e $800^{\circ} \mathrm{C}$, que possivelmente estão relacionados com a decomposição dos carbonatos em $\mathrm{CO}$ e $\mathrm{CO}_{2}$ e dos carbonatos intermediários, respectivamente. Com relação aos picos exotérmicos, o primeiro ocorre em $300^{\circ} \mathrm{C}$ (NSM10) e $240{ }^{\circ} \mathrm{C}$ (NSM30 e NSM50) e refere-se principalmente a eliminação de água de cristalização presente em cada material. O segundo pico ocorre aproximadamente entre 700 e $800^{\circ} \mathrm{C}$ e está relacionado com o rearranjo da estrutura cristalina.

O estudo da decomposição e transformações dos carbonatos precursores é importante para definir a temperatura de calcinação mais adequada para a síntese do NSM. Com base nos resultados obtidos através das análises térmicas e segundo a literatura técnica relacionada à síntese de $\mathrm{NSM}^{(7,8)}$, definiuse a temperatura de $1000{ }^{\circ} \mathrm{C}$ com um patamar de 4 horas para a etapa de calcinação dos carbonatos misturados.

Segundo alguns autores ${ }^{(11,35)}$, temperaturas de calcinação inferiores a $1000{ }^{\circ} \mathrm{C}$ podem ser adequadas, mas não garante a sintetização (formação) completa do NSM e, temperaturas superiores, não são indicadas devido ao início de pré-sinterização. 


\subsection{Caracterização dos Pós}

\subsubsection{Avaliação do teor de carbono residual}

Para a verificação da quantidade de carbono residual existente em cada amostra após a etapa de calcinação, utilizou-se a cromatografia de absorção gasosa. Os resultados são apresentados na Tabela 5.2, mostrando que existe uma considerável quantidade de carbono após a etapa de calcinação e indicando que o tempo de 4 horas não foi suficiente para eliminar o carbono residual presente em cada material. Por esse motivo, foi realizado um tratamento térmico a $1000^{\circ} \mathrm{C}$ e por mais 4 horas para diminuir o teor de carbono encontrado.

Tabela 5.2 - Teor de carbono após as etapas de calcinação e tratamento térmico.

\begin{tabular}{cccc}
\cline { 2 - 3 } & \multicolumn{2}{c}{$\begin{array}{c}\text { Teor de Carbono } \\
\text { (\% em massa) }\end{array}$} \\
\hline Amostra & Calcinação & $\begin{array}{c}\text { Tratamento } \\
\text { Térmico }\end{array}$ & $\begin{array}{c}\text { Redução } \\
\text { (\%) }\end{array}$ \\
\hline NSM10 & 0,6223 & 0,0074 & 98,81 \\
NSM30 & 0,3424 & 0,0020 & 99,41 \\
NSM50 & 0,4587 & 0,0103 & 97,75 \\
\hline
\end{tabular}

Os resultados indicam que o percentual de carbono residual ainda era considerável após a calcinação, mas após o tratamento térmico houve uma redução de mais de $97,50 \%$ em todas as amostras, confirmando que para sintetizar o NSM através da técnica de mistura de sólidos e praticamente sem a presença de carbono residual, é necessário um tempo de pelo menos 8 horas a uma temperatura de $1000^{\circ} \mathrm{C}$.

\subsubsection{Composição química}

A composição química foi determinada por análise de espectrometria de fluorescência de raios X por energia dispersiva (FRX-EDS). Analisaram-se os pós sintetizados de NSM, com a finalidade de identificar a estequiometria real dos elementos químicos em cada composição. Por meio de cálculos matemáticos, determinou-se o valor (em \% molar) da estequiometria obtida para cada um dos compostos de NSM. Os resultados são apresentados na Tabela 5.3. 
Tabela 5.3 - Valores obtidos por FRX e estequiometria real dos materiais em estudo.

\begin{tabular}{|c|c|c|c|}
\hline Amostra & $\begin{array}{c}\text { Composto } \\
\text { Teórico }\end{array}$ & $\begin{array}{c}\text { Elementos Químicos } \\
(\% \text { em Massa) }\end{array}$ & $\begin{array}{l}\text { Composto } \\
\text { Obtido }\end{array}$ \\
\hline NSM10 & $\mathrm{Nd}_{0,90} \mathrm{Sr}_{0,10} \mathrm{MnO}_{3}$ & $\begin{array}{l}\mathrm{Nd}=42,30 \pm 0,10 \\
\mathrm{Sr}=4,90 \pm 0,10 \\
\mathrm{MnO}_{3}=52,80 \pm 0,10\end{array}$ & $\mathrm{Nd}_{0,84} \mathrm{Sr}_{0,16} \mathrm{MnO}_{3}$ \\
\hline NSM30 & $\mathrm{Nd}_{0,70} \mathrm{Sr}_{0,30} \mathrm{MnO}_{3}$ & $\begin{array}{l}\mathrm{Nd}=34,60 \pm 0,10 \\
\mathrm{Sr}=12,20 \pm 0,10 \\
\mathrm{MnO}_{3}=53,20 \pm 0,10\end{array}$ & $\mathrm{Nd}_{0,63} \mathrm{Sr}_{0,37} \mathrm{MnO}_{3}$ \\
\hline NSM50 & $\mathrm{Nd}_{0,50} \mathrm{Sr}_{0,50} \mathrm{MnO}_{3}$ & $\begin{array}{l}\mathrm{Nd}=26,90 \pm 0,10 \\
\mathrm{Sr}=19,80 \pm 0,10 \\
\mathrm{MnO}_{3}=53,30 \pm 0,10\end{array}$ & $\mathrm{Nd}_{0,45} \mathrm{Sr}_{0,55} \mathrm{MnO}_{3}$ \\
\hline
\end{tabular}

Através da FRX, pode-se concluir que a estequiometria real ficou relativamente próxima à teórica, entretanto, percebe-se que houve uma perda estequiométrica devido, provavelmente, à formação de pequena quantidade de óxido de neodímio $\left(\mathrm{Nd}_{2} \mathrm{O}_{3}\right)$ em altas temperaturas, ocasionada pela segregação de neodímio durante a rota de síntese.

\subsubsection{Diâmetro médio equivalente de aglomerados}

$\mathrm{Na}$ análise granulométrica por espalhamento, utilizando feixes de laser, foi determinado o diâmetro médio equivalente por massa acumulada dos pós sintetizados de NSM após a etapa de moagem, como demonstrado na Figura 5.2.

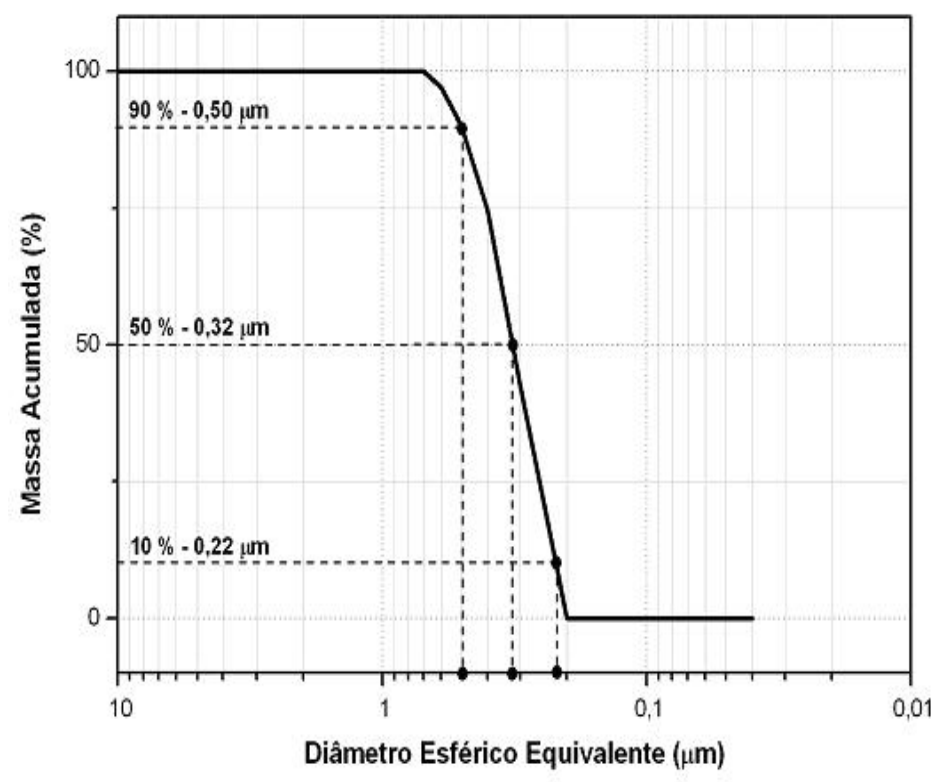

Figura 5.2 - Distribuição granulométrica para as amostras de NSM. 
As curvas características de massa acumulada (\%) versus diâmetro esférico equivalente ficaram idênticas para os três materiais (NSM10, NSM30 e NSM50), indicando o diâmetro médio de pós aglomerados.

Os resultados obtidos, apresentados na Tabela 5.4, mostram que para os pós de NSM, o diâmetro médio equivalente é de aproximadamente $0,35 \mu \mathrm{m}$. Tais granulometrias são adequadas, de acordo com a literatura ${ }^{(7,8,97)}$, ao processamento destes pós para a preparação de suspensões e deposição como filmes finos sobre os substratos de eletrólitos sólidos.

Tabela 5.4 - Diâmetros médios equivalentes obtidos por distribuição granulométrica.

\begin{tabular}{cc}
\hline Amostra & Diâmetro Médio Equivalente $(\boldsymbol{\mu m})$ \\
\hline NSM10 & 0,35 \\
NSM30 & 0,35 \\
NSM50 & 0,35 \\
\hline
\end{tabular}

As possíveis explicações para igualdade dos resultados estão relacionadas ao modelo de FRAUNHOFER ${ }^{(81)}$ que foi utilizado para a análise de distribuição granulométrica, pois este modelo, é mais adequado para partículas bastante maiores que $1 \mu \mathrm{m}$. Entretanto, os materiais foram processados nas mesmas condições de moagem e peneiramento. O modelo de MIE ${ }^{(81)}$ seria mais correto para a análise desses três materiais, mas é necessário saber o índice de refração do NSM (não disponível na literatura técnica).

\subsubsection{Diâmetro médio efetivo de aglomerados}

Como não foi possível a determinação do diâmetro médio através do modelo de MIE, buscou-se outra técnica para avaliar o diâmetro das partículas dos materiais em estudo e melhorar a confiabilidade do resultado neste trabalho.

Com isso, o diâmetro médio também foi determinado utilizando um analisador de potencial zeta ${ }^{(82)}$. Este equipamento possui um dispositivo para determinar o diâmetro médio efetivo de partículas. É chamado de efetivo porque a técnica utiliza o princípio da dispersão de partículas e feixes de laser, sendo que pelo fato das partículas estarem em suspensão em um meio líquido (geralmente água deionizada), forma-se uma camada bem fina de água em volta da partícula 
(conhecida como dupla camada). Como a dupla camada é quase insignificante, o diâmetro médio efetivo é obtido com razoável precisão.

Os resultados obtidos, apresentados na Tabela 5.5, mostram que para os pós de NSM, o diâmetro médio efetivo está no intervalo de $0,26 \mu \mathrm{m}$ a 0,30 $\mu \mathrm{m}$.

Tabela 5.5 - Diâmetros médios efetivos obtidos no zetâmetro.

\begin{tabular}{cc}
\hline Amostra & Diâmetro Médio Efetivo $(\boldsymbol{\mu m})$ \\
\hline NSM10 & 0,26 \\
NSM30 & 0,30 \\
NSM50 & 0,26 \\
\hline
\end{tabular}

Tais granulometrias comprovam a validade dos resultados obtidos pela distribuição granulométrica, mesmo com a limitação do modelo de FRAUNHOFER, e sendo realmente adequadas ao processamento destes pós para a preparação de suspensões e posterior deposição como filmes finos sobre os substratos de eletrólitos sólidos.

\subsection{5. Área de superfície específica}

A área superficial específica foi determinada por adsorção gasosa (B.E.T.). Os valores das áreas superficiais específicas de cada amostra são apresentados na Tabela 5.6. Os pós foram calcinados a $1000{ }^{\circ} \mathrm{C}$ com um patamar de 4 horas, tratados termicamente a $1000^{\circ} \mathrm{C}$ também durante 4 horas, moídos por 12 horas em moinho atritor e peneirados.

Tabela 5.6 - Área superficial específica das amostras em estudo.

\begin{tabular}{cc}
\hline Amostra & Área Superficial Específica $\left(\mathbf{m}^{2} / \mathbf{g}\right)$ \\
\hline NSM10 & $10,1 \pm 0,1$ \\
NSM30 & $8,8 \pm 0,1$ \\
NSM50 & $7,9 \pm 0,1$ \\
\hline
\end{tabular}

Através dos resultados obtidos, percebe-se que para as três amostras de pós de NSM, os valores de área superficial específica estão razoavelmente dentro da mesma ordem de grandeza. 


\subsubsection{Diâmetro médio de partícula}

O diâmetro médio de partícula (D) foi calculado utilizando os valores de área de superfície específica $(S)$ obtidos e os valores das densidades teóricas $\left(\rho_{t}\right)$ de cada material, calculadas através de parâmetros de rede refinados e disponíneis nos bancos de dados JCPDS. Os resultados calculados são apresentados na Tabela 5.7.

Tabela 5.7 - Diâmetros médios de partículas das amostras NSM10, NSM30 e NSM50.

\begin{tabular}{cccc}
\hline Amostra & $\boldsymbol{\rho}_{\mathrm{t}}\left(\mathbf{g} / \mathbf{c m}^{3}\right)$ & $\mathbf{S}\left(\mathbf{m}^{2} / \mathbf{g}\right)$ & $\mathbf{D}(\boldsymbol{\mu m})$ \\
\hline NSM10 & 6,68 & 10,11 & 0,09 \\
NSM30 & 6,64 & 8,77 & 0,10 \\
NSM50 & 6,40 & 7,88 & 0,12 \\
\hline
\end{tabular}

Os valores de diâmetros médios de partículas entre as amostras de NSM são bastante próximos entre si, mostrando a mesma característica encontrada na distribuição granulométrica e no zetâmetro. Entretanto é importante mencionar que os valores estão abaixo se comparado com os obtidos experimentalmente, comprovando também que as técnicas experimentais medem diâmetro médio de aglomerados de partículas.

\subsubsection{Densidade real}

A massa específica via picnometria de gás hélio, que é uma medida representativa da densidade real do material, foi obtida. Os resultados são apresentados na Tabela 5.8. Para os pós de NSM10, o valor obtido experimentalmente corresponde a $92,81 \%$ da densidade teórica; de NSM30 corresponde a 93,07 \% e NSM50, corresponde a 91,40\%. As densidades teóricas foram obtidas nos bancos de dados de DRX e serão discutidas mais adiante.

Tabela 5.8 - Densidades reais das amostras de NSM.

\begin{tabular}{cc}
\hline Amostra & Densidade Real $\mathbf{( g / \mathbf { c m } ^ { 3 } )}$ \\
\hline NSM10 & $6,200 \pm 0,004$ \\
NSM30 & $6,180 \pm 0,007$ \\
NSM50 & $5,850 \pm 0,007$ \\
\hline
\end{tabular}


Os resultados obtidos mostram que as concentrações do dopante estrôncio estudadas neste trabalho não afetam de forma muito significativa as densidades dos pós sintetizados de NSM.

\subsubsection{Estrutura cristalina}

Por difratometria de raios $X(D R X)$, verificou-se a formação da estrutura cristalina característica para cada amostra. A Figura 5.3 apresenta os difratogramas dos pós de NSM10, NSM30 e NSM50.

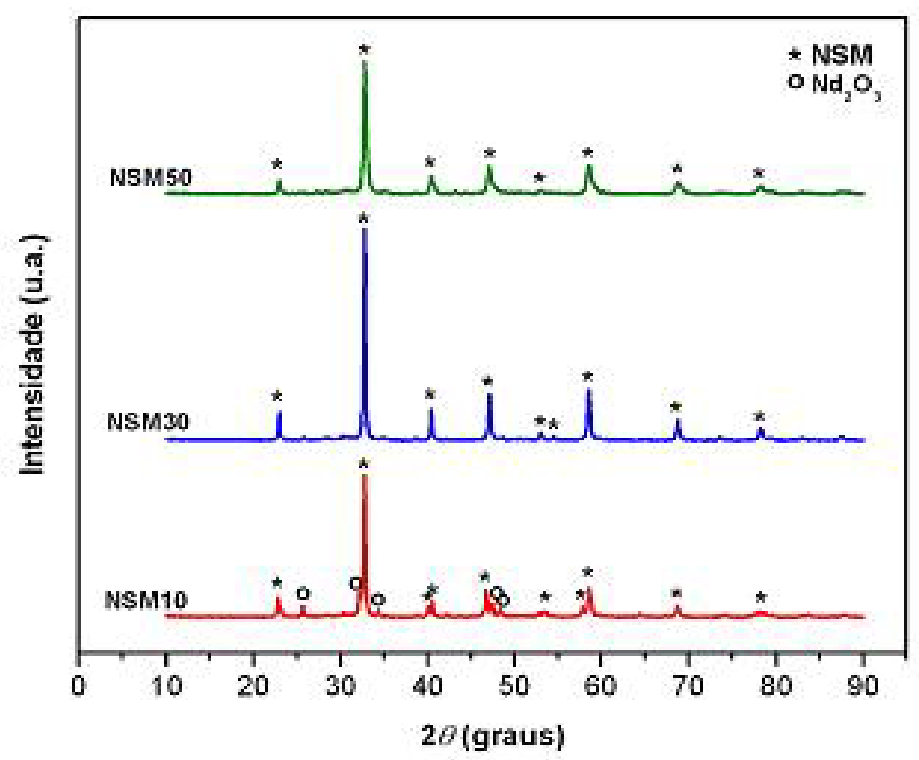

Figura 5.3 - Difratogramas obtidos por DRX dos pós de NSM10, NSM30 e NSM50.

A caracterização por DRX para os pós de NSM foi baseada no trabalho de ARUNA et al. ${ }^{(95)}$. Para as concentrações de neodímio (Nd) e de estrôncio (Sr) utilizadas neste trabalho espera-se obter uma estrutura pseudo-perovskita ortorrômbica, segundo os autores anteriormente citados. Os resultados obtidos utilizando os difratogramas são apresentados na Tabela 5.9.

Tabela 5.9 - Estrutura cristalina e parâmetros de rede das amostras sintetizadas.

\begin{tabular}{ccccc}
\hline \multirow{2}{*}{ Amostra } & Estrutura & \multicolumn{3}{c}{ Parâmetros de Rede $(\AA)$} \\
\cline { 3 - 5 } & Cristalina & a & b & c \\
\hline NSM10 & Ortorrômbica & 5,4599 & 5,4600 & 7,7110 \\
NSM30 & Ortorrômbica & 5,4494 & 5,4547 & 7,9640 \\
NSM50 & Ortorrômbica & 5,4310 & 5,4700 & 7,6250 \\
\hline
\end{tabular}


A partir dos resultados, e comparando com os trabalhos de KOSTOGLOUDIS et al. ${ }^{(15)}$ e SAKAKI et al. ${ }^{(7)}$, pode-se comprovar a formação de uma estrutura pseudo-perovskita ortorrômbica e a presença de uma pequena quantidade de óxido de neodímio $\left(\mathrm{Nd}_{2} \mathrm{O}_{3}\right)$ nas amostras de NSM.

Os cálculos de parâmetros de rede foram possíveis, devido ao programa Crystallographica Search Match (CSM), que permitiu encontrar os parâmetros de rede utilizando os bancos de dados JCPDS existentes desses materiais, com suas respectivas estruturas cristalinas e grupos espaciais. $O$ programa Celref possibilitou o cálculo de refinamento dos parâmetros de rede das amostras NSM10, NSM30 e NSM50. A identificação foi visual e comparativa para se confirmar à estrutura cristalina e seus respectivos parâmetros refinados.

Para a amostra NSM10, identificou-se à presença de uma pequena quantidade de $\mathrm{Nd}_{2} \mathrm{O}_{3}$ (JCPDS $\mathrm{n}^{\circ}$ 000-86-1531) proveniente da não total reação de estado sólido com os íons segregados de $\mathrm{Nd}^{3+}$. Os resultados das estruturas cristalinas, dos parâmetros de rede e da presença de $\mathrm{Nd}_{2} \mathrm{O}_{3}$ estão de acordo com os valores apresentados por SAKAKI et.al. ${ }^{(7)}$.

A presença de $\mathrm{Nd}^{3+}$ na forma de $\mathrm{Nd}_{2} \mathrm{O}_{3}$ é influenciada pelo raio iônico do íon. $\mathrm{O}$ íon $\mathrm{Nd}^{3+}$ possui um raio iônico de $1,08 \AA$ enquanto que o íon $\mathrm{Sr}^{2+}$ possui um raio iônico de $1,13 \AA^{(8)}$. Pelo fato do raio iônico do íon $\mathrm{Sr}^{2+}$ ser maior do que o íon $\mathrm{Nd}^{3+}$ ocorre uma limitação e posterior substituição do neodímio pelo estrôncio na estrutura pseudo-perovskita $\mathrm{NdMnO}_{3}{ }^{(7,8)}$.

\subsubsection{Morfologia}

A morfologia das partículas dos pós obtidos após calcinação foi observada por microscopia eletrônica de varredura (MEV). As micrografias apresentadas (Figura 5.4) mostram nitidamente a homogeneidade dos aglomerados de partículas e que o tamanho médio de muitos desses aglomerados são inferiores a $1 \mu \mathrm{m}$.

Analisando com mais atenção as micrografias obtidas e comparando com os valores de diâmetros médios de partículas encontrados pela distribuição granulométrica e pelo zetâmetro, percebe-se realmente a formação de grande quantidade de aglomerados bem homogêneos para os três pós sintetizados. 


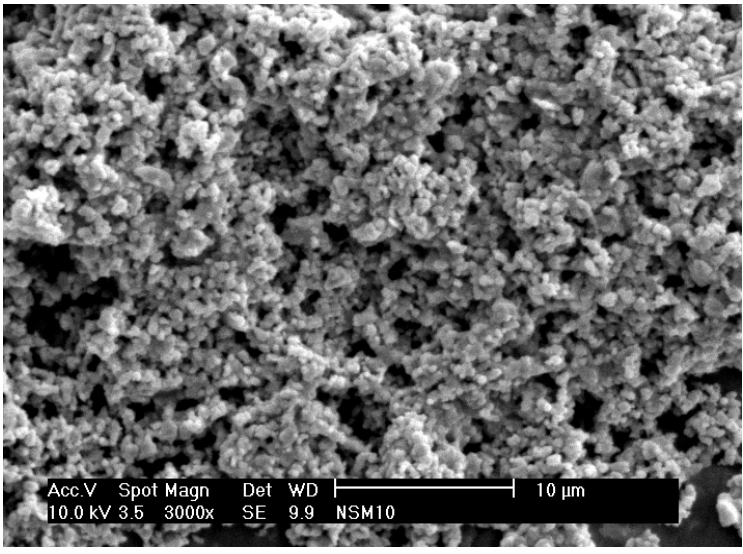

(a)

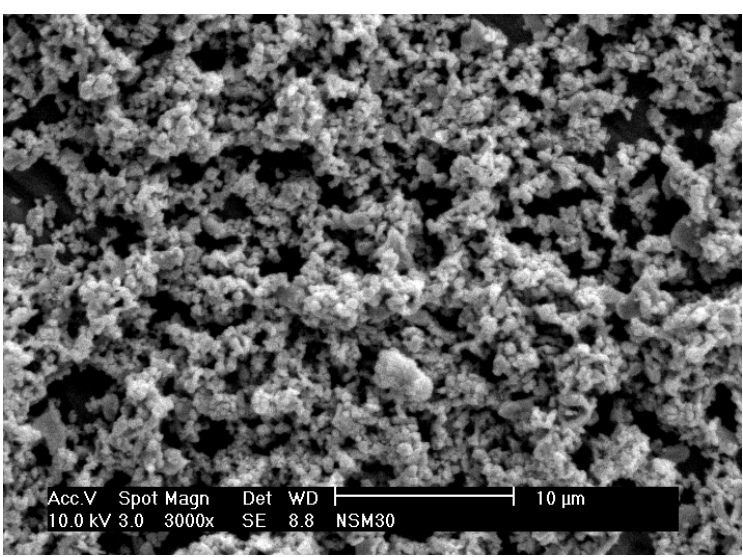

(c)

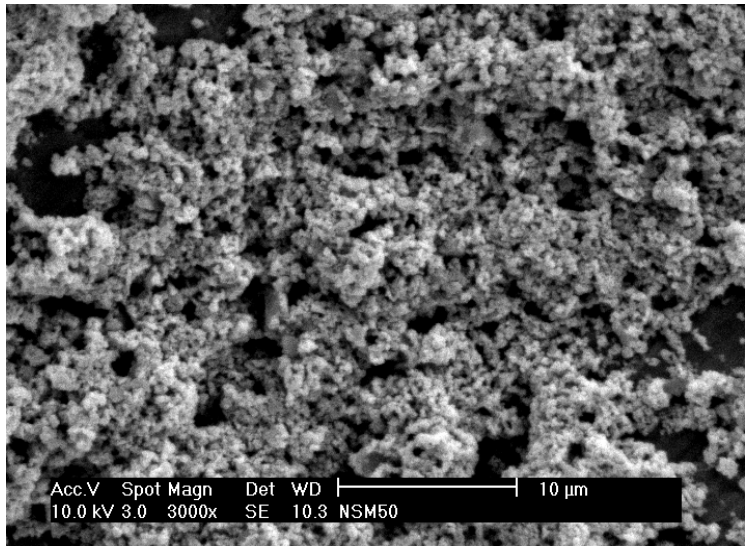

(e)

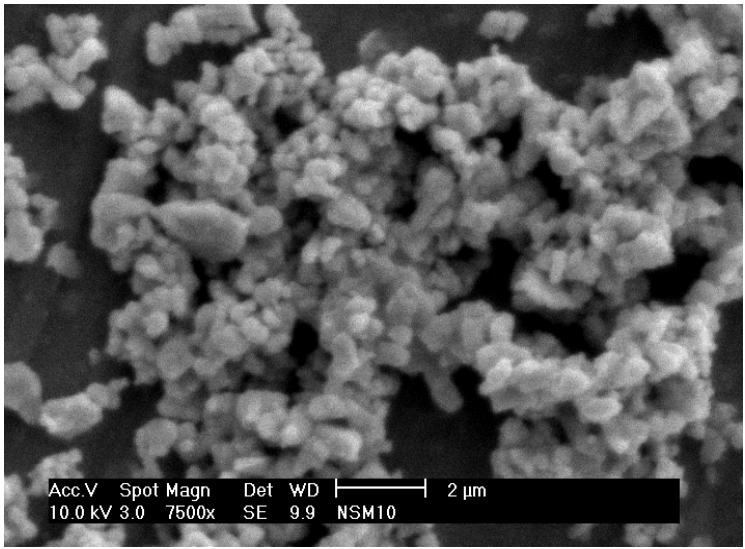

(b)

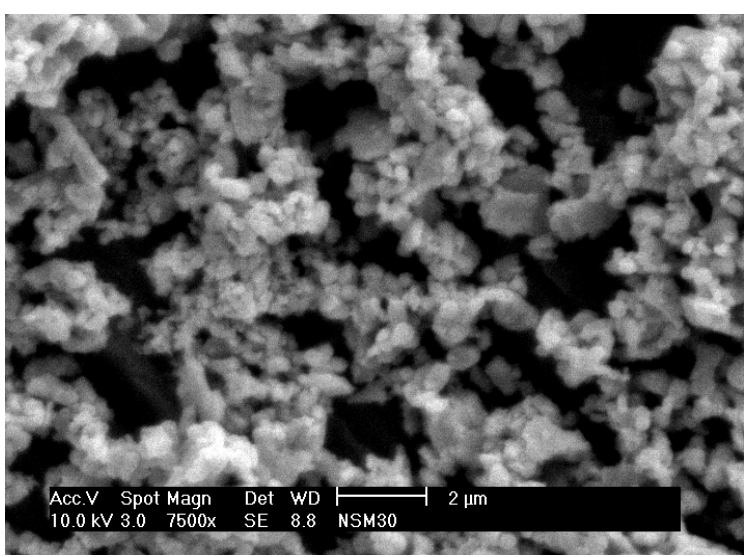

(d)

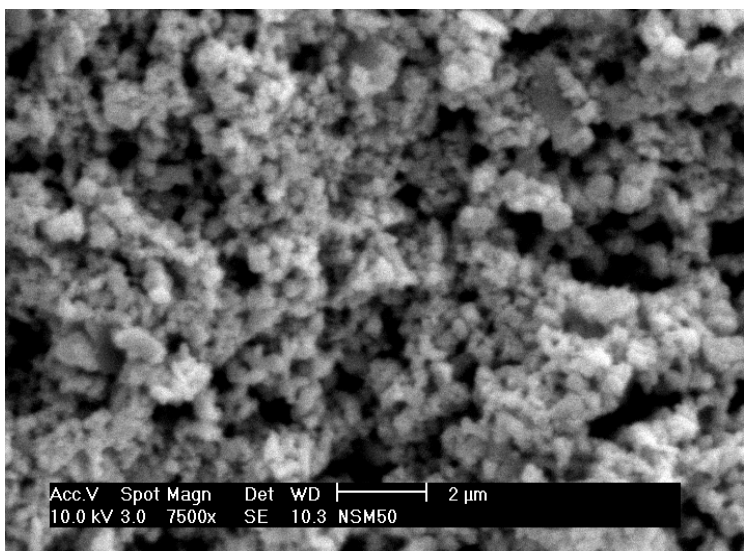

(f)

Figura 5.4 - Micrografias dos pós de NSM10(a,b), NSM30(c,d) e NSM50(e,f).

\subsection{Estudo de Processo}

\subsubsection{Dilatometria}

Antes de entrar nas discussões das caracterizações das cerâmicas, serão apresentados os resultados de dilatometria das amostras a verde de NSM. 
Os resultados demonstrados na Figura 5.5 apresentam as curvas de retração linear $(\mu \mathrm{m})$ em função do aumento de temperatura $\left({ }^{\circ} \mathrm{C}\right)$. Analisando as curvas de aquecimento, verifica-se que 0 início da retração ocorre aproximadamente a $900{ }^{\circ} \mathrm{C}$ e mais especificamente no intervalo entre $1000 \mathrm{a}$ $1300{ }^{\circ} \mathrm{C}$ ocorre à taxa máxima de retração linear e, acima de $1350{ }^{\circ} \mathrm{C}$, as amostras se encontram com alta densificação. A realização da dilatometria (expansão térmica) é de grande importância para selecionar as temperaturas mais adequadas para o processo de sinterização das amostras em estudo para posterior estudo das suas características físicas e microestruturais.

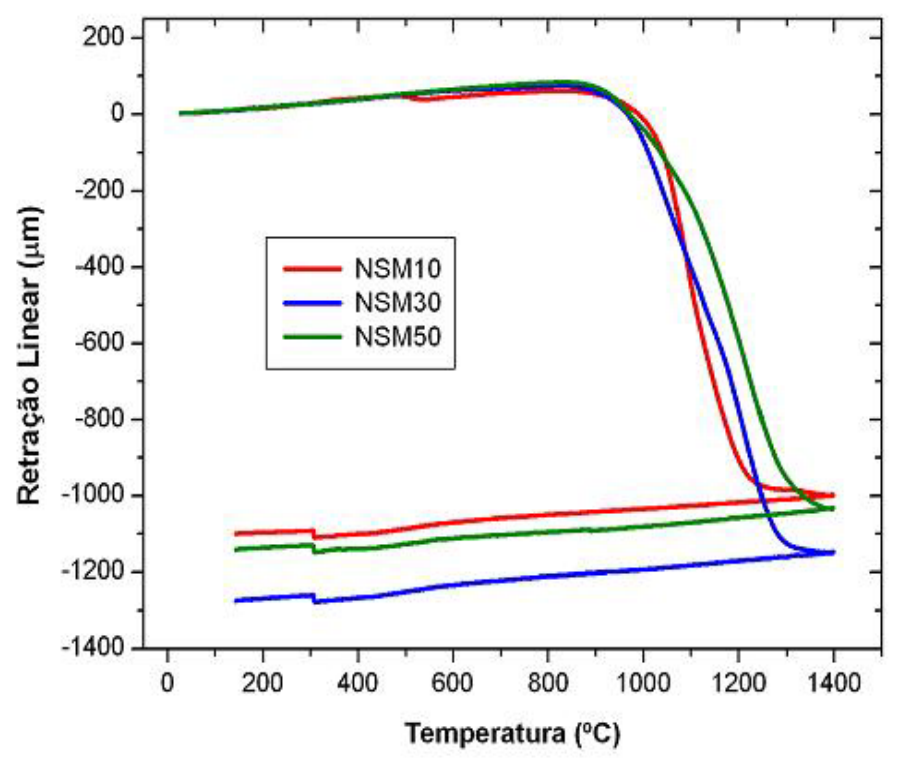

Figuras 5.5 - Curvas de retração linear das amostras NSM10, NSM30 e NSM50.

De acordo com os resultados obtidos através da dilatometria, as temperaturas entre 1000 e $1300^{\circ} \mathrm{C}$ são as mais adequadas à realização das etapas de sinterização para estudo de um material catódico em SOFCs. Entretanto, o material foi sintetizado a $1000^{\circ} \mathrm{C}$ e dessa forma, não se espera uma sinterização mínima adequada a esta temperatura. Com base nesses resultados e de acordo com a literatura ${ }^{(7,8,15,95)}$, adotou-se as temperaturas de 1100, 1200, 1300 e $1400^{\circ} \mathrm{C}$ por 4 horas para sinterizar as amostras de NSM.

A temperatura de $1400^{\circ} \mathrm{C}$ foi adotada como um estudo comparativo em relação às demais, mas de acordo com a literatura ${ }^{(5,9)}$, esta temperatura não é a mais indicada para conseguir um material adequado para aplicação em SOFCs, devido à sinterização estar em estado avançado e com baixa porosidade para aplicação do material como um componente catódico. 


\subsection{Caracterização das Cerâmicas}

\subsubsection{Densidade geométrica a verde}

As amostras preparadas para a sinterização foram pesadas e anotadas as suas massas secas $(\mathrm{g})$ e medidos os diâmetros $(\mathrm{mm})$ e as espessuras $(\mathrm{mm})$ para os cálculos da densidade geométrica das pastilhas não sinterizadas. Os valores das densidades geométricas das pastilhas a "verde" se encontram na Tabela 5.10, os quais são da mesma ordem de grandeza, pois diminuem relativamente pouco com o aumento do teor de estrôncio.

Tabela 5.10 - Valores das densidades geométricas a "verde" dos materiais em estudo.

\begin{tabular}{cc}
\hline Amostra & Densidade Geométrica a "Verde" $\left(\mathbf{g} / \mathbf{c m}^{3}\right)$ \\
\hline NSM10 & 3,64 \\
NSM30 & 3,60 \\
NSM50 & 3,38 \\
\hline
\end{tabular}

5.4.2. Densidade geométrica dos sinterizados

As amostras NSM10, NSM30 e NSM50 em forma de pastilhas cilíndricas foram sinterizadas a 1100, 1200, 1300 e $1400{ }^{\circ} \mathrm{C}$ por 4 horas. As temperaturas de 1100 a $1300{ }^{\circ} \mathrm{C}$ foram adotadas de acordo com os resultados da análise de dilatometria, pois estão presentes na faixa de maior retrações lineares, ou seja, na faixa em que está ocorrendo sinterização.

A temperatura de $1400{ }^{\circ} \mathrm{C}$ está fora da faixa de retração linear e indica que as amostras estão em processo de sinterização avançado. Esta temperatura foi adotada apenas para estudo de comparação em relação às anteriores.

Todas as amostras sinterizadas foram pesadas e anotadas as suas massas secas $(\mathrm{g})$ e medidos os diâmetros $(\mathrm{mm})$ e as espessuras $(\mathrm{mm})$ para 0 cálculo da densidade geométrica das pastilhas sinterizadas (Tabela 5.11).

Tabela 5.11 - Valores das densidades geométricas dos sinterizados.

\begin{tabular}{ccccc}
\hline \multirow{2}{*}{ Amostra } & \multicolumn{4}{c}{ Densidade Geométrica dos Sinterizados $\mathbf{( \mathbf { g } / \mathbf { c m } ^ { \mathbf { 3 } } )}$} \\
\cline { 2 - 5 } & $\mathbf{1 1 0 0}{ }^{\circ} \mathbf{C}$ & $\mathbf{1 2 0 0}{ }^{\circ} \mathbf{C}$ & $\mathbf{1 3 0 0}{ }^{\circ} \mathbf{C}$ & $\mathbf{1 4 0 0}{ }^{\circ} \mathbf{C}$ \\
\hline NSM10 & 5,30 & 5,75 & 5,84 & 5,87 \\
NSM30 & 5,68 & 5,88 & 6,18 & 6,22 \\
NSM50 & 5,72 & 5,93 & 6,21 & 6,28 \\
\hline
\end{tabular}


De acordo com os resultados obtidos das densidades, observa-se que à medida que a temperatura de sinterização aumenta, existe um aumento significativo nos valores das densidades geométricas para todas as amostras. Analogamente, à medida que aumenta o teor do dopante estrôncio, há acréscimos nos valores das densidades após as sinterizações.

\subsubsection{Densidade aparente dos sinterizados}

Após a etapa de sinterização, foram medidas a massa úmida (g) e a massa imersa $(\mathrm{g})$ de todas as amostras com o objetivo de calcular a densidade aparente (densidade hidrostática) obtida pelo princípio de Arquimedes. Os valores das densidades aparentes se encontram na Tabela 5.12.

Tabela 5.12 - Valores das densidades aparentes dos materiais após sinterização.

\begin{tabular}{ccccc}
\hline \multirow{2}{*}{ Amostra } & \multicolumn{4}{c}{ Densidade Aparente dos Sinterizados $\left(\mathbf{g} / \mathbf{c m}^{3}\right)$} \\
\cline { 2 - 5 } & $\mathbf{1 1 0 0}{ }^{\circ} \mathbf{C}$ & $\mathbf{1 2 0 0}{ }^{\circ} \mathbf{C}$ & $\mathbf{1 3 0 0}{ }^{\circ} \mathbf{C}$ & $\mathbf{1 4 0 0}{ }^{\circ} \mathbf{C}$ \\
\hline NSM10 & 4,30 & 4,62 & 4,93 & 4,98 \\
NSM30 & 4,67 & 4,98 & 5,16 & 5,32 \\
NSM50 & 5,11 & 5,18 & 5,19 & 5,49 \\
\hline
\end{tabular}

De acordo com os resultados obtidos das densidades, observa-se que à medida que a temperatura de sinterização aumenta, existe também um aumento significativo nos valores das densidades aparentes para todas as amostras. Analogamente, à medida que aumenta o teor do dopante estrôncio, há também acréscimos nos valores das densidades após as sinterizações.

\subsubsection{Densidade teórica e porosidade}

As densidades teóricas das amostras sinterizadas de NSM10, NSM30 e NSM50 foram calculadas utilizando os parâmetros de rede disponíveis nos bancos de dados JCPDS de difração de raios $\mathrm{X}$.

A partir dos valores de densidades aparente e teórica, foram calculadas as porosidades (em \%) correspondentes (Tabela 5.13). 
Tabela 5.13 - Valores das porosidades calculadas.

\begin{tabular}{cccccc} 
& & \multicolumn{4}{c}{ Porosidade (\%) } \\
\cline { 2 - 6 } Amostra & $\boldsymbol{\rho}_{\mathrm{t}}\left(\mathbf{g} / \mathbf{c m}^{\mathbf{3}}\right)$ & $\mathbf{1 1 0 0}{ }^{\circ} \mathbf{C}$ & $\mathbf{1 2 0 0}{ }^{\circ} \mathbf{C}$ & $\mathbf{1 3 0 0}{ }^{\circ} \mathbf{C}$ & $\mathbf{1 4 0 0}{ }^{\circ} \mathbf{C}$ \\
\hline NSM10 & 6,68 & 35,63 & 30,84 & 26,20 & 25,45 \\
NSM30 & 6,64 & 29,67 & 25,00 & 22,29 & 19,88 \\
NSM50 & 6,40 & 20,16 & 19,06 & 18,81 & 14,22 \\
\hline
\end{tabular}

Os valores encontrados estão abaixo do esperado, devido à presença de porosidade fechada que não pode ser medida pelo princípio de Arquimedes, portanto, as porosidades calculadas na Tabela 5.13 são valores aproximados e certamente um pouco abaixo dos valores reais. Verifica-se que os valores de porosidades estão de acordo com a literatura ${ }^{(16,17)}$. A maioria das amostras apresenta valores de porosidades abaixo do intervalo entre 30 e $40 \%$ que é recomendado como ideal para o catodo de SOFCs.

\subsubsection{Estrutura cristalina}

Os difratogramas de raios $X$ para todas as amostras sinterizadas a 1100, 1200, 1300 e $1400{ }^{\circ} \mathrm{C}$ são apresentados na Figuras 5.6, 5.7 e 5.8. Igualmente para todas as amostras, verificaram-se as formações das estruturas cristalinas pseudo-perovskitas ortorrômbicas, como também a presença de $\mathrm{Nd}_{2} \mathrm{O}_{3}$, assim como encontrado também nas amostras em forma de pós.

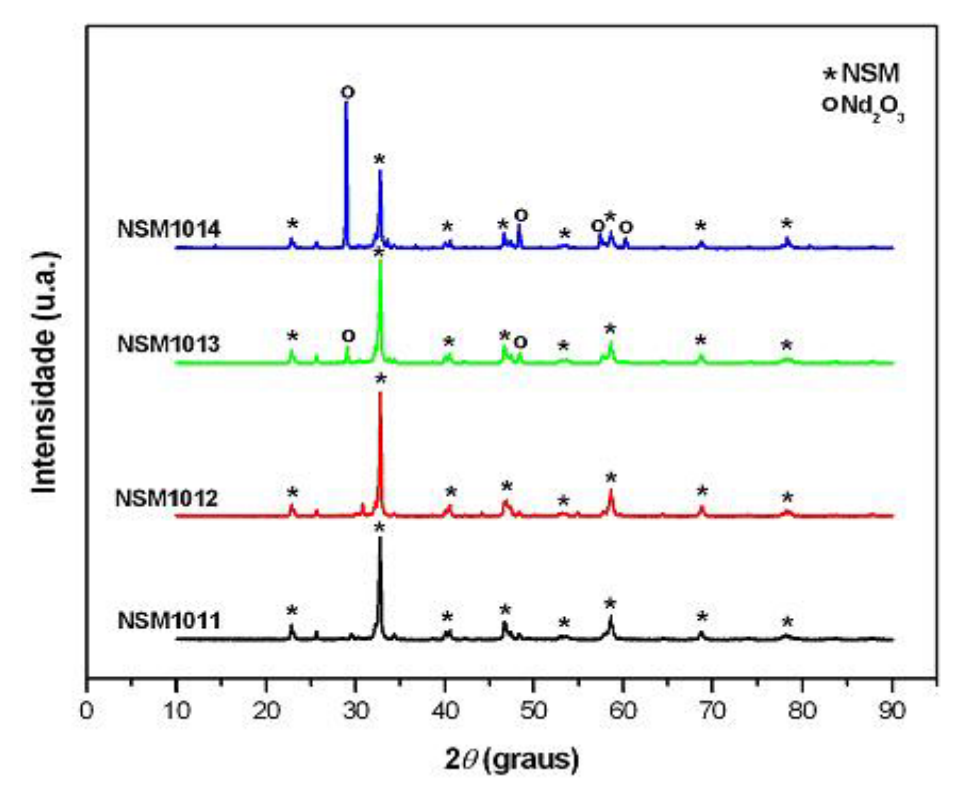

Figura 5.6 - DRX das amostras sinterizadas de NSM10. 


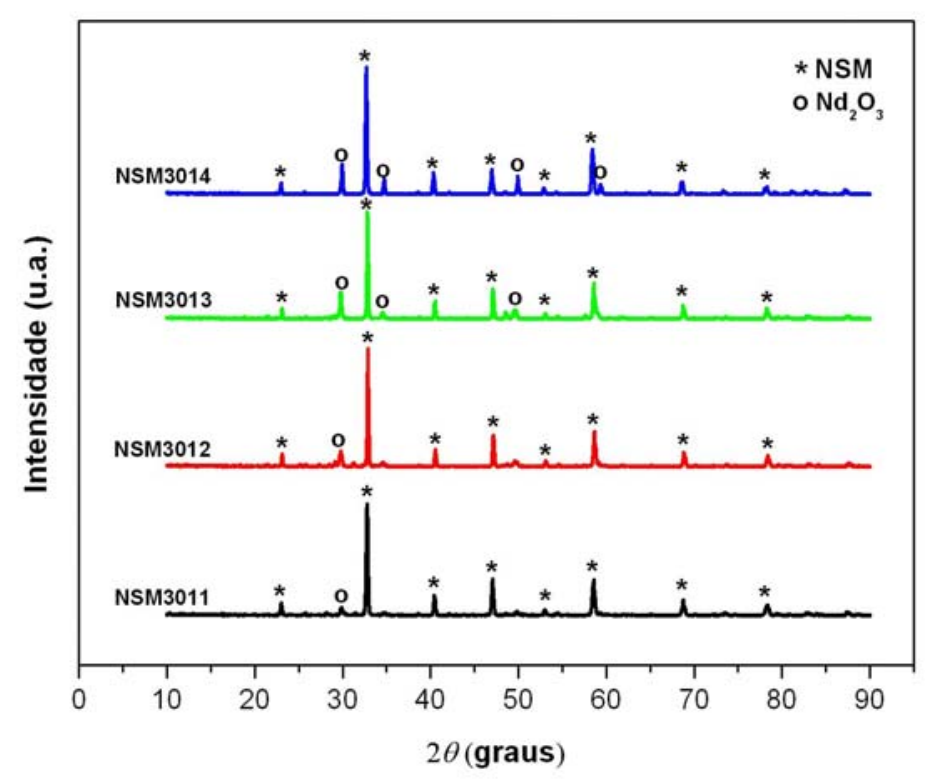

Figura 5.7 - DRX das amostras sinterizadas de NSM30.

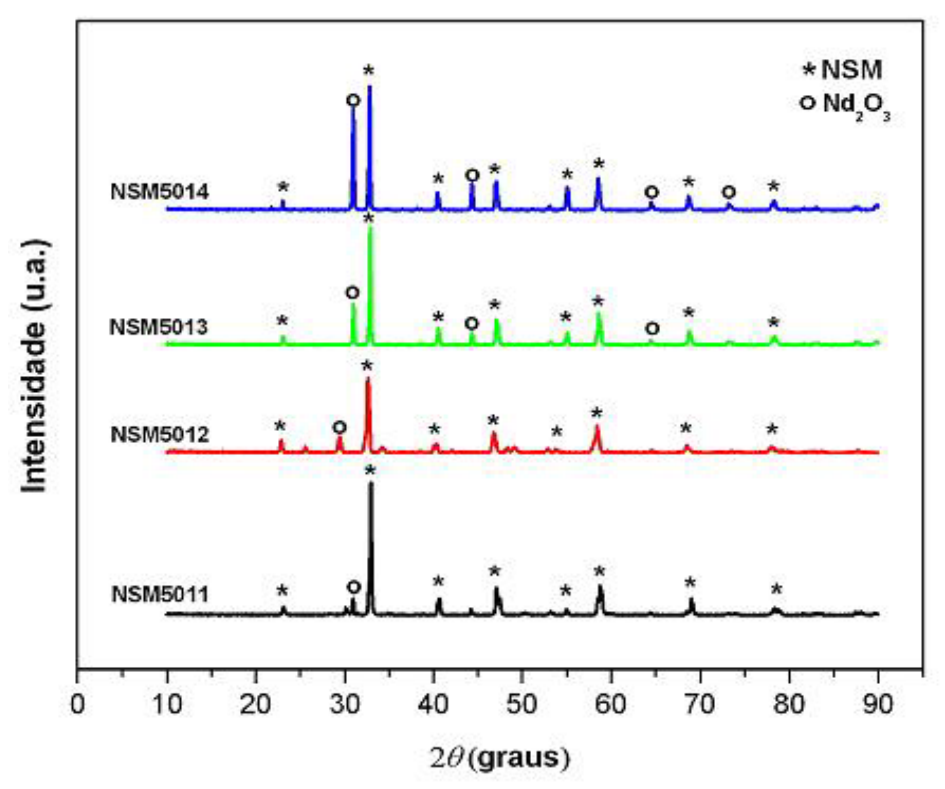

Figura 5.8 - DRX das amostras sinterizadas de NSM50.

A caracterização por DRX para os pós de NSM foi baseada nos trabalhos de WEN et al. (8), SAKAKI et al. ${ }^{(7)}$ e ARUNA et al. ${ }^{(95)}$. Para as concentrações de neodímio ( $\mathrm{Nd}$ ) e de estrôncio $(\mathrm{Sr})$ utilizadas neste trabalho espera-se obter uma estrutura pseudo-perovskita ortorrômbica.

Para as amostras da série NSM10, foi utilizado o arquivo JCPDS número 000-86-1531, para as amostras da série NSM30, o arquivo número 00086-1534 a série NSM50, foi utilizado o arquivo JCPDS número 000-87-1537. 
Os resultados encontrados mostram que praticamente não existe transformação de estrutura cristalina das pastilhas sinterizadas em relação às amostras sintetizadas em forma de pós, indicando que existe uma estabilização de fase a uma temperatura de sinterização de até $1200{ }^{\circ} \mathrm{C}$. Entretanto, a 1300 e $1400{ }^{\circ} \mathrm{C}$ ocorre um aumento significativo da fase secundária de $\mathrm{Nd}_{2} \mathrm{O}_{3}$.

\subsubsection{Superfícies fraturadas}

A análise por microscopia eletrônica de varredura (MEV) foi utilizada para a observação das superfícies de fratura das amostras sinterizadas, principalmente quanto ao aspecto da presença de porosidade. Os resultados indicam que à medida que aumenta a temperatura de sinterização, ocorre diminuição nos valores de porosidade (Figuras 5.9, 5.10 e 5.11).

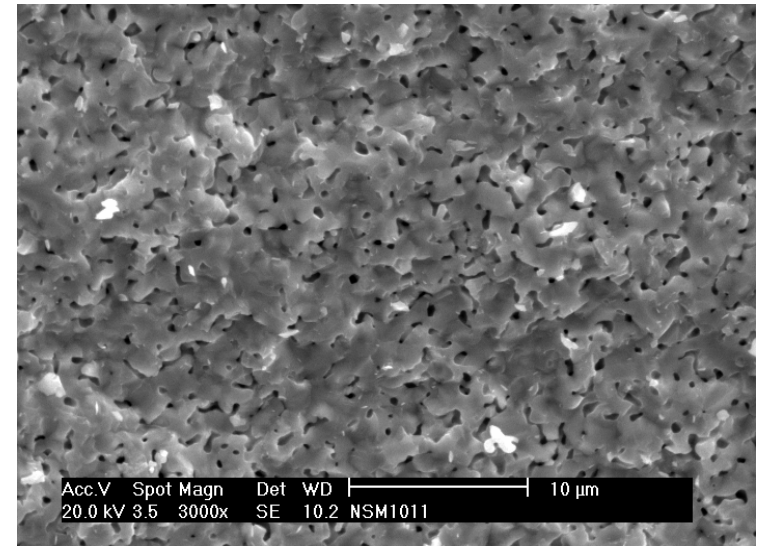

(a)

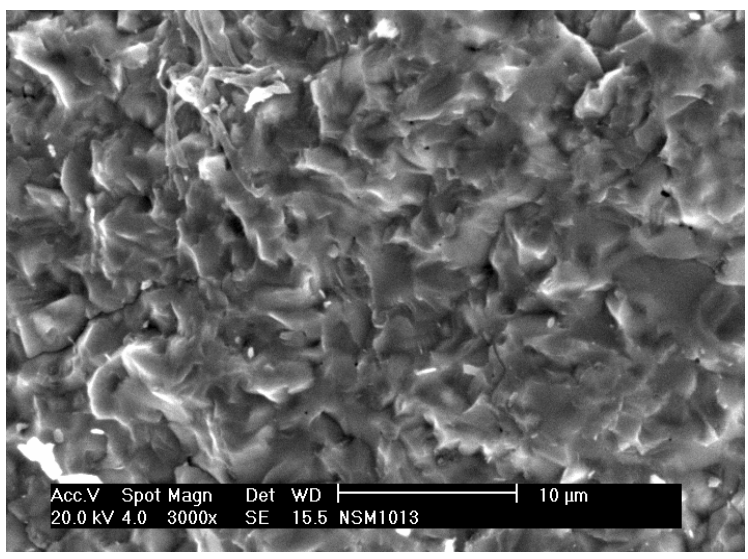

(c)

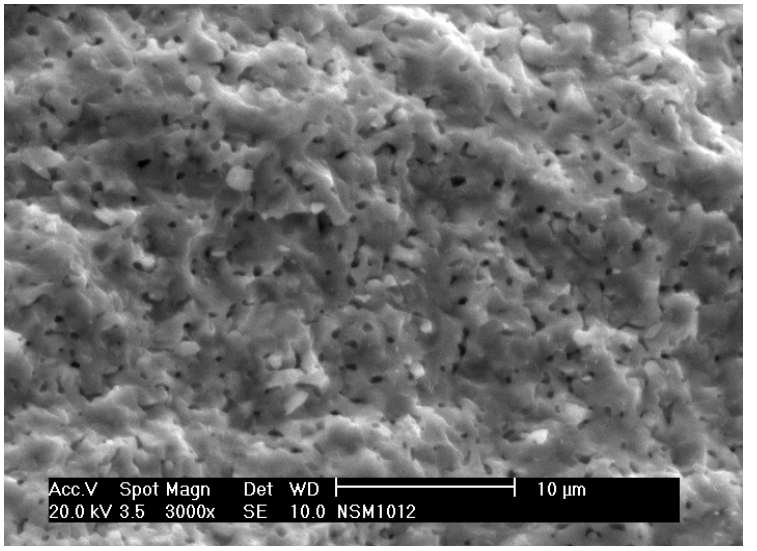

(b)

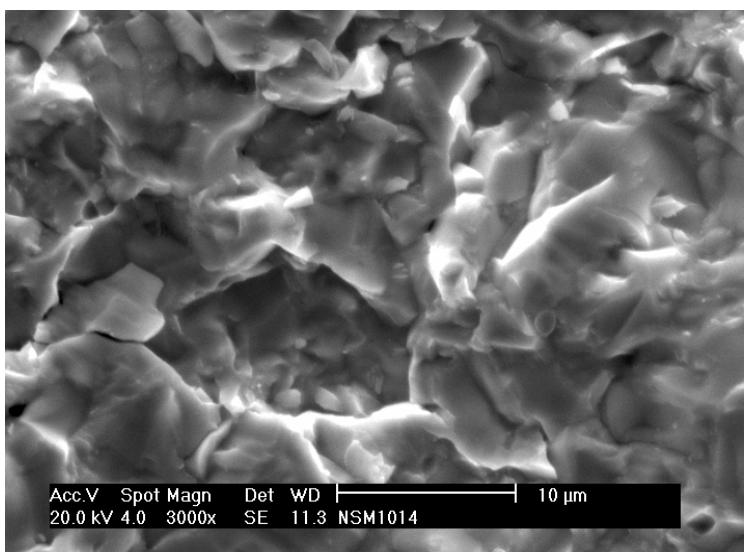

(d)

Figura 5.9 - Micrografias obtidas por MEV, das pastilhas cerâmicas fraturadas e sinterizadas de NSM1011(a), NSM1012(b), NSM1013(c) e NSM1014(d). 
As superfícies de fratura das amostras NSM1011 e NSM1012, sinterizadas a 1100 e $1200^{\circ} \mathrm{C}$, respectivamente, apresentam maior quantidade de poros pequenos distribuídos homogeneamente, enquanto que a $1300{ }^{\circ} \mathrm{C}$ (NSM1013) observa-se uma menor quantidade de poros pequenos distribuídos através da superfície de fratura. Para a superfície fraturada da amostra que foi sinterizada a $1400^{\circ} \mathrm{C}$ (NSM1014) observa-se também uma pequena quantidade de poros pequenos e um aspecto de superfície bem sinterizada.

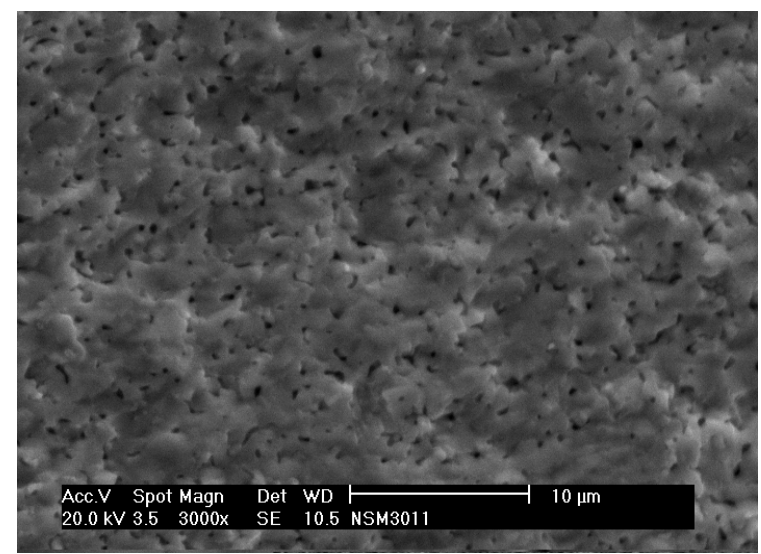

(a)

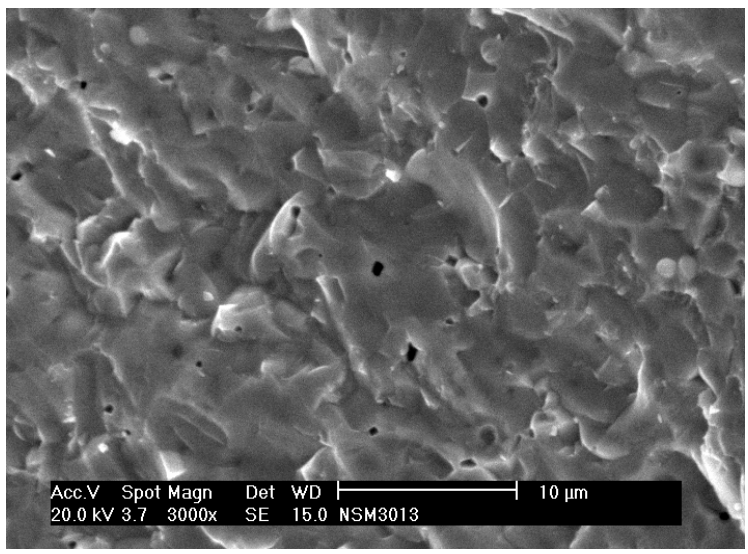

(c)

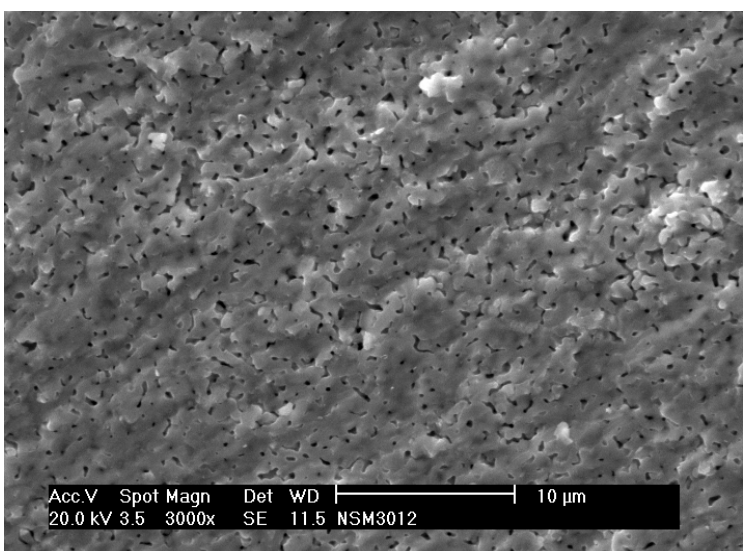

(b)

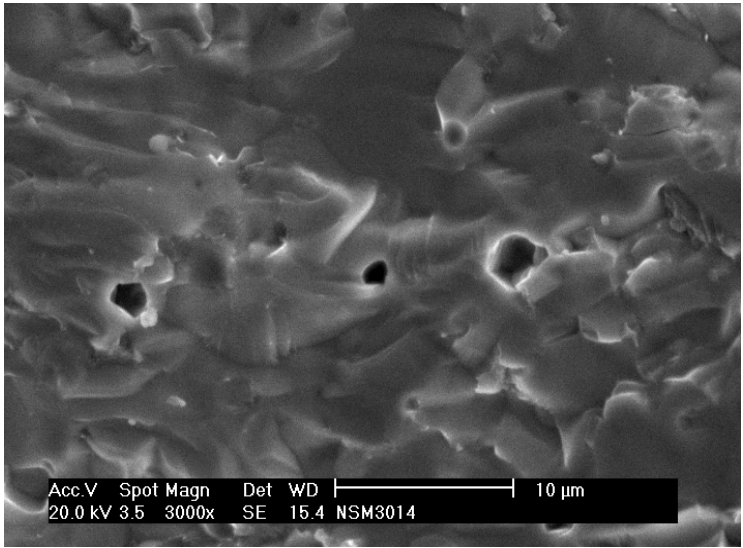

(d)

Figura 5.10 - Micrografias obtidas por MEV, das pastilhas cerâmicas fraturadas e sinterizadas de NSM3011(a), NSM3012(b), NSM3013(c) e NSM3014(d).

As superfícies de fratura das amostras NSM3011 e NSM3012, sinterizadas a 1100 e $1200{ }^{\circ} \mathrm{C}$, respectivamente, também apresentam maior quantidade de poros pequenos distribuídos homogeneamente, enquanto que a $1300{ }^{\circ} \mathrm{C}$ (NSM1013) observa-se uma razoável quantidade de poros pequenos distribuídos através da micrografia. 
Para a superfície fraturada da amostra sinterizada a $1400{ }^{\circ} \mathrm{C}$ (NSM3014) observa-se uma pequena quantidade de poros maiores na superfície da micrografia, que pode ser devido à coalescência dos poros pequenos.

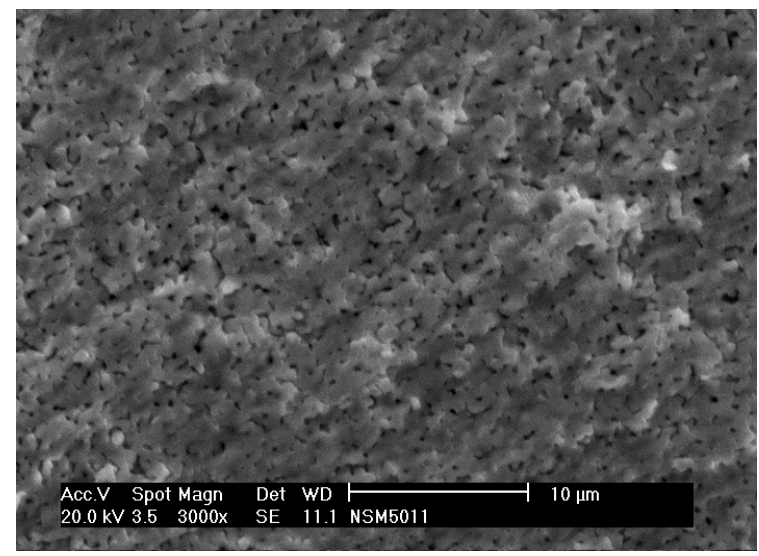

(a)

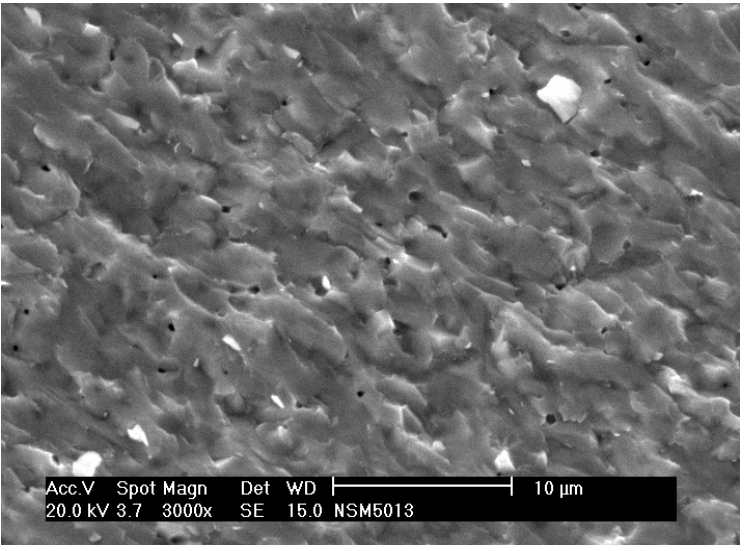

(c)

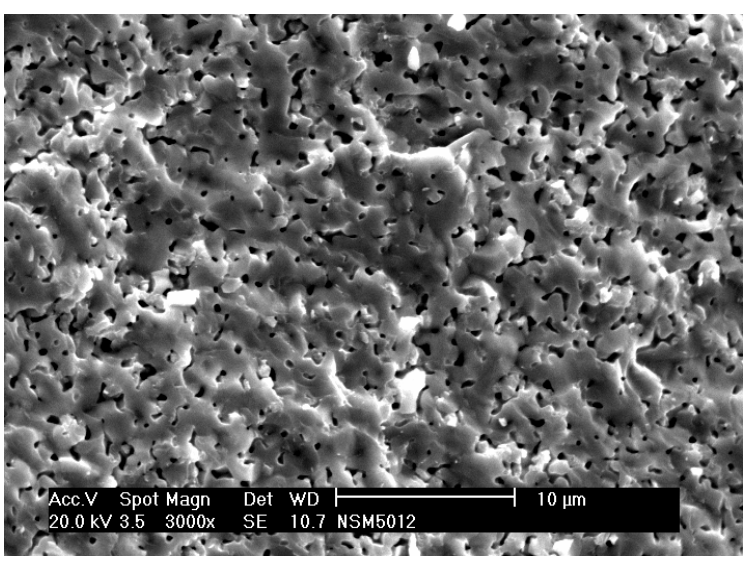

(b)

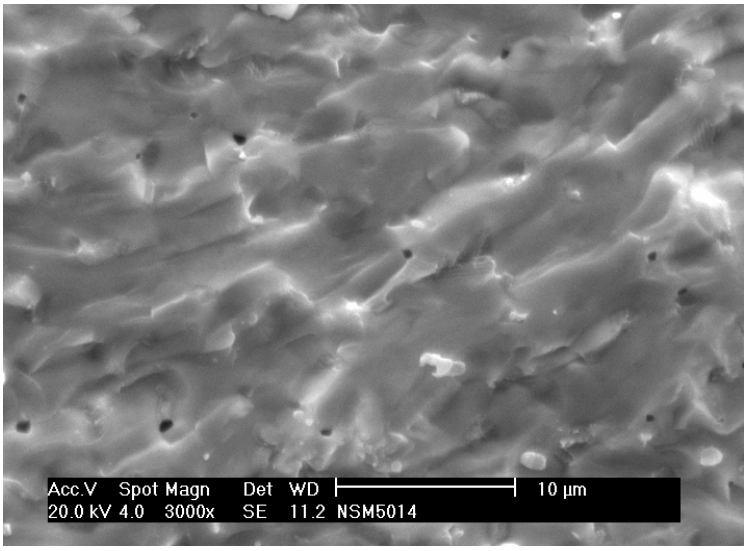

(d)

Figura 5.11 - Micrografias obtidas por MEV, das pastilhas cerâmicas fraturadas e sinterizadas de NSM5011(a), NSM5012(b), NSM5013(c) e NSM5014(d).

As superfícies de fratura das amostras NSM5011 e NSM5012, sinterizadas a 1100 e $1200{ }^{\circ} \mathrm{C}$, respectivamente, apresentam maior quantidade de poros pequenos distribuídos, enquanto que a $1300{ }^{\circ} \mathrm{C}$ (NSM1013) e a $1400{ }^{\circ} \mathrm{C}$ (NSM5014) observa-se uma pequena quantidade de poros pequenos distribuídos aleatoriamente na superfície.

Com os resultados obtidos através das micrografias, as amostras sinterizadas a 1100 e $1200{ }^{\circ} \mathrm{C}$ apresentaram os melhores resultados visuais, comprovando os resultados encontrados nos cálculos de porosidade. Observa-se também que o aspecto da fratura em todas as micrografias é intragranular. 


\subsubsection{Superfícies fraturadas atacadas termicamente}

De acordo com os resultados anteriores, foram selecionadas as amostras sinterizadas a 1100 e a $1200{ }^{\circ} \mathrm{C}$ para a observação das superfícies por MEV das amostras lixadas, polidas e atacadas termicamente por 60 minutos (Figuras 5.12 a 5.14), para a revelação dos contornos de grãos.

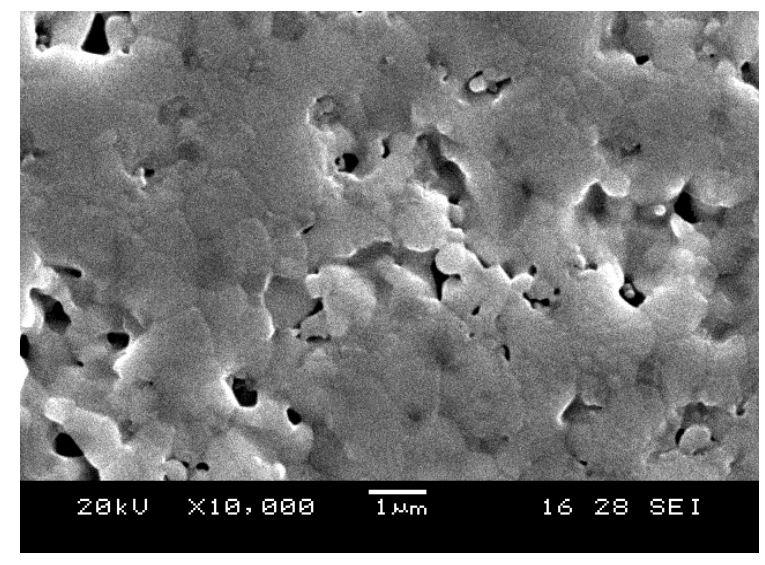

(a)

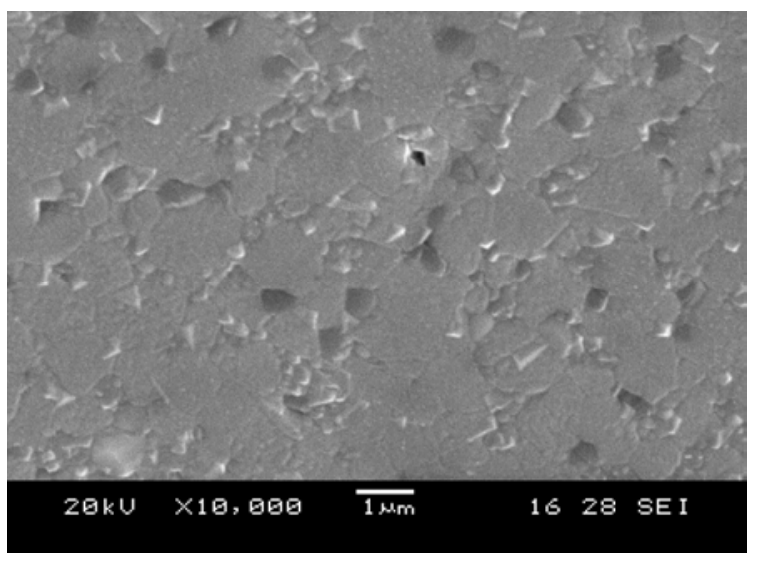

(b)

Figura 5.12 - Micrografias obtidas por MEV, das pastilhas cerâmicas atacadas termicamente de NSM1011(a) e NSM1012(b).

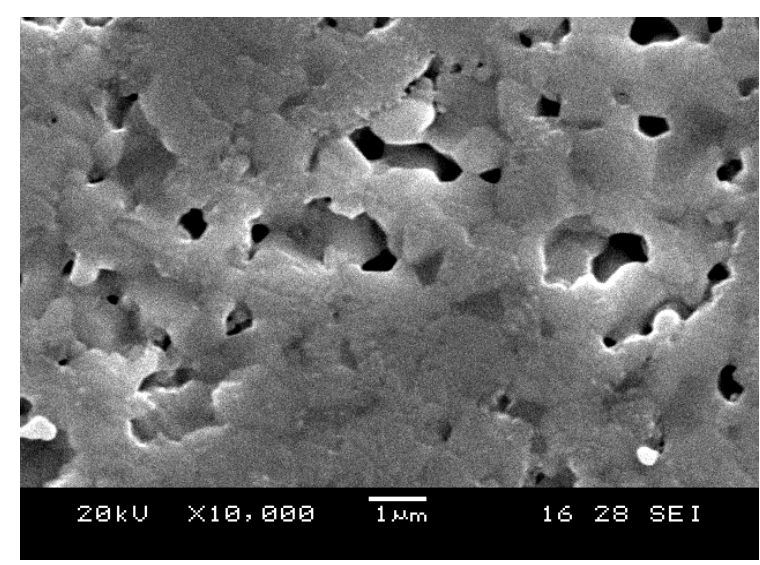

(a)

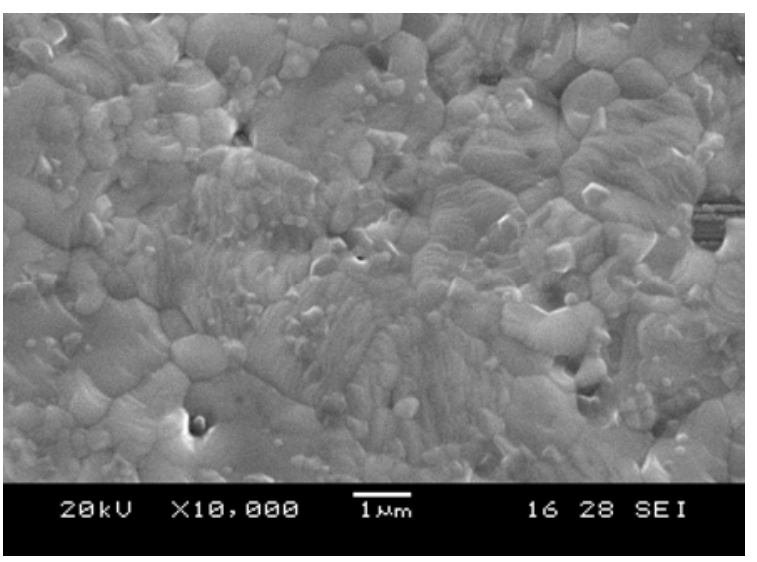

(b)

Figura 5.13 - Micrografias obtidas por MEV, das pastilhas cerâmicas atacadas termicamente de NSM3011(a) e NSM3012(b). 


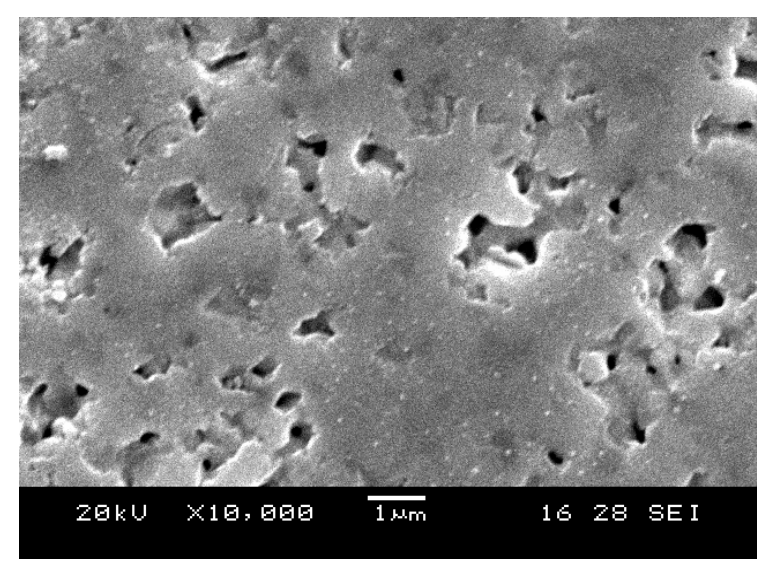

(a)

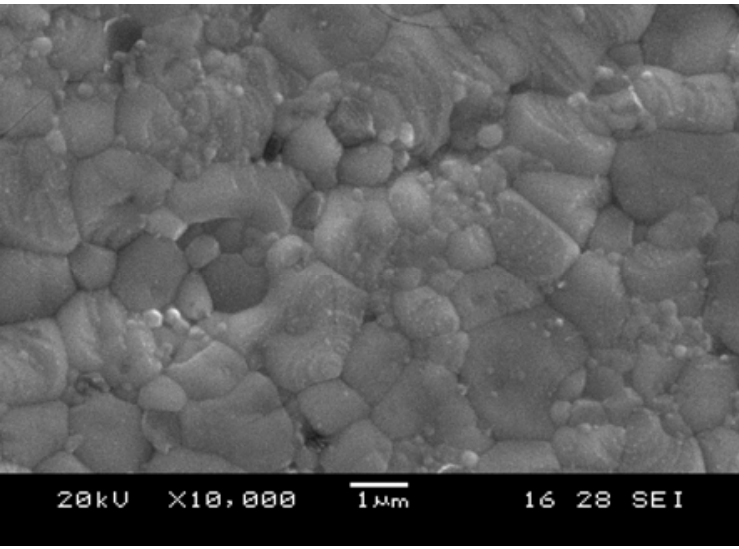

(b)

Figura 5.14 - Micrografias obtidas por MEV, das pastilhas cerâmicas atacadas termicamente de NSM5011(a) e NSM5012(b).

Os resultados indicam que nas amostras NSM1011, NSM3011 e NSM5011, os grãos aparecem discretamente e, conseqüentemente, a sua microestrutura não está totalmente definida. A visualização dos contornos de grãos nas amostras NSM1012, NSM3012 e NSM5012 são bem mais nítidas e mostram os contornos de grãos presentes na superfície que foi atacada termicamente (choque térmico) durante 60 minutos.

Tais resultados demonstram que as amostras sinterizadas a $1200{ }^{\circ} \mathrm{C}$ possuem os melhores resultados, entretanto a distribuição dos contornos de grãos está distribuída de uma forma homogênea para a amostra NSM1012 e em sua maioria heterogênea para as amostras NSM3012 e NSM5012. Isso pode ser explicado devido à própria rota de síntese do material que ocorre com reações no estado sólido em temperaturas elevadas e também ao alto tempo de choque térmico, fazendo com que ocorra crescimento de grãos de forma aleatória.

No início foram realizados choques térmicos de 20 e 40 minutos com as mesmas condições, entretanto, os resultados não foram satisfatórios, pois os grãos não eram revelados de forma adequada para visualização.

\subsubsection{Tamanho médio de grãos}

Apesar da pouca heterogeneidade, é possível estimar de uma forma razoável, o tamanho médio de grãos das amostras sinterizadas a $1200{ }^{\circ} \mathrm{C}$. De uma forma visual, percebe-se que o tamanho médio dos grãos da amostra NSM1012 está entre 0,5 e $2 \mu \mathrm{m}$. 
Visualizando com um pouco de atenção as amostras NSM3012 e NSM5012, percebemos que o tamanho médio de grãos está entre 0,5 e $3 \mu \mathrm{m}$.

De acordo com a literatura, o tamanho de grão influencia de forma significativa nos resultados de expansão térmica e condutividade elétrica, sendo que para conseguir resultados considerados adequados para a aplicação requerida, os tamanhos médios de grãos devem ser inferiores a $5 \mu \mathrm{m}{ }^{(66,67,96)}$.

\subsubsection{Expansão térmica}

O estudo da expansão térmica das amostras sinterizadas é de grande importância, pois as SOFCs operam em diferentes ciclos térmicos e em temperaturas que variam atualmente de 500 a $800{ }^{\circ} \mathrm{C}$ para a ITSOFC e 800 a $1000^{\circ} \mathrm{C}$ para a HTSOFC. As pseudo-peroviskitas de manganito de lantânio (LSM) têm sido largamente empregadas como catodos em HTSOFCs, devido principalmente à compatibilidade na expansão térmica com o eletrólito de $Y S Z$, cujo valor é da ordem de $10,3 \times 10^{-6}{ }^{\circ} \mathrm{C}^{-1}$ ao ${ }^{(10)}$.

As medidas de expansão térmica linear das pastilhas sinterizadas foram efetuadas desde a temperatura ambiente até $1000{ }^{\circ} \mathrm{C}$ com velocidade de aquecimento de $2{ }^{\circ} \mathrm{C} / \mathrm{min}$ (em ar) e resfriamento de $10{ }^{\circ} \mathrm{C} / \mathrm{min}$. Os resultados obtidos são apresentados na Figura 5.15.

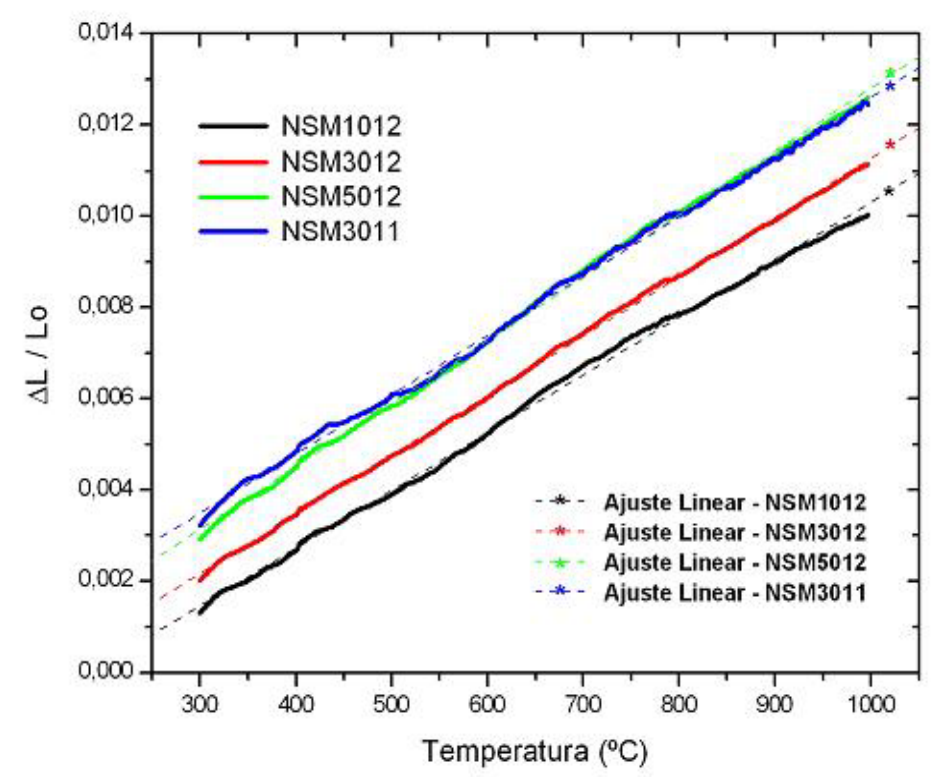

Figura 5.15 - Expansão térmica das amostras sinterizadas de NSM. 
Os valores calculados dos coeficientes de expansão térmica (TEC) para os materiais em estudo são apresentados na Tabela 5.14.

Tabela 5.14 - TEC das amostras em estudo.

\begin{tabular}{ccc}
\hline \multirow{2}{*}{ Amostra } & \multicolumn{2}{c}{ TEC $\left(\mathbf{\times 1 \mathbf { 1 0 } ^ { - 6 } \mathbf { C } ^ { - \mathbf { 1 } } )}\right.$} \\
\cline { 2 - 3 } & $\mathbf{( \mathbf { 2 5 } \mathbf { ~ a ~ } \mathbf { 0 0 0 } { } ^ { \circ } \mathbf { C } )}$ & $\left.\mathbf{( 5 0 0} \mathbf{a ~ 8 0 0}{ }^{\circ} \mathbf{C}\right)$ \\
\hline NSM1012 & 12,65 & 13,10 \\
NSM3012 & 13,03 & 13,31 \\
NSM5012 & 13,81 & 14,11 \\
NSM3011 & 13,01 & 13,96 \\
\hline
\end{tabular}

Os resultados obtidos estão bastante próximos aos coeficientes de expansão térmica de catodos similares e de eletrólitos sólidos encontrados na literatura ${ }^{(96)}$, além de eletrólitos comerciais ${ }^{(97)}$ Segundo alguns pesquisadores $(7,8,10,15,95)$, os valores dos coeficientes diminuem até $\mathrm{x} \leq 0,10(10 \% \mathrm{em} \mathrm{mol})$ de $\mathrm{Sr}$ e aumentam conforme o acréscimo de Sr. As amostras NSM1012, NSM3012 e NSM3011 apresentam os valores do coeficiente de expansão térmica muito próximos do eletrólito comercial de GDC (Céria Dopada com Gadolínia), cujo valor é em torno de $13,4 \times 10^{-6}{ }^{\circ} \mathrm{C}^{-1}$ e SDC (Céria Dopada com Samária), cujo valor é em torno de $12,7 \times 10^{-6}{ }^{\circ} \mathrm{C}^{-1}(97)$. A amostra NSM50 apresenta o coeficiente um pouco elevado, confirmando que maiores concentrações de $\mathrm{Sr}$ eleva ligeiramente os coeficientes de expansão térmica.

Segundo HAMMOUCHE e colaboradores ${ }^{(92)}$, existem acréscimos da expansão térmica do material à medida que aumentam os valores de " $x$ " (entre 0,05 e 0,50). Em relação aos resultados presentes na literatura técnica, quanto maior o valor de " $x$ " tanto maior será a diferença entre os coeficientes de expansão térmica do eletrodo catódico (catodo) e do eletrólito, tornando o material não aplicável como componente catódico para a ITSOFC.

\subsubsection{Condutividade elétrica}

O estudo da condutividade elétrica das amostras sinterizadas também é de grande importância para avaliar se um eletrodo é adequado ao uso em CaCs. A medida de condutividade elétrica $\left(\Omega^{-1 *} \mathrm{~cm}^{-1}\right)$ de materiais cerâmicos contém informações importantes referentes principalmente ao contorno de grão e a sua estrutura cristalina ${ }^{(25)}$. 
Para determinarmos a condutividade elétrica, precisamos primeiramente encontrar a resistividade elétrica $\left(\Omega^{*} \mathrm{~cm}\right)$ em função da temperatura $\left({ }^{\circ} \mathrm{C}\right)$. A resistividade, também conhecida como resistência específica, nada mais é do que o inverso da condutividade e vice-versa.

Os resultados apresentados pelas amostras NSM1012, NSM3012 e NSM5012 evidenciam que a resistividade elétrica (Figura 5.16) dos compostos estudados de NSM possuem um comportamento termicamente ativado em ampla faixa de temperatura. De maneira geral, todas as composições não apresentaram uma alteração relativamente significativa entre as medidas realizadas ao ar (pressão parcial de $\mathrm{O}_{2}=0,21 \mathrm{~atm}$ ). Para as medidas, todas as amostras foram cortadas no formato de um paralelepípedo com dimensões de 2 × 2 × $8 \mathrm{~mm}$.

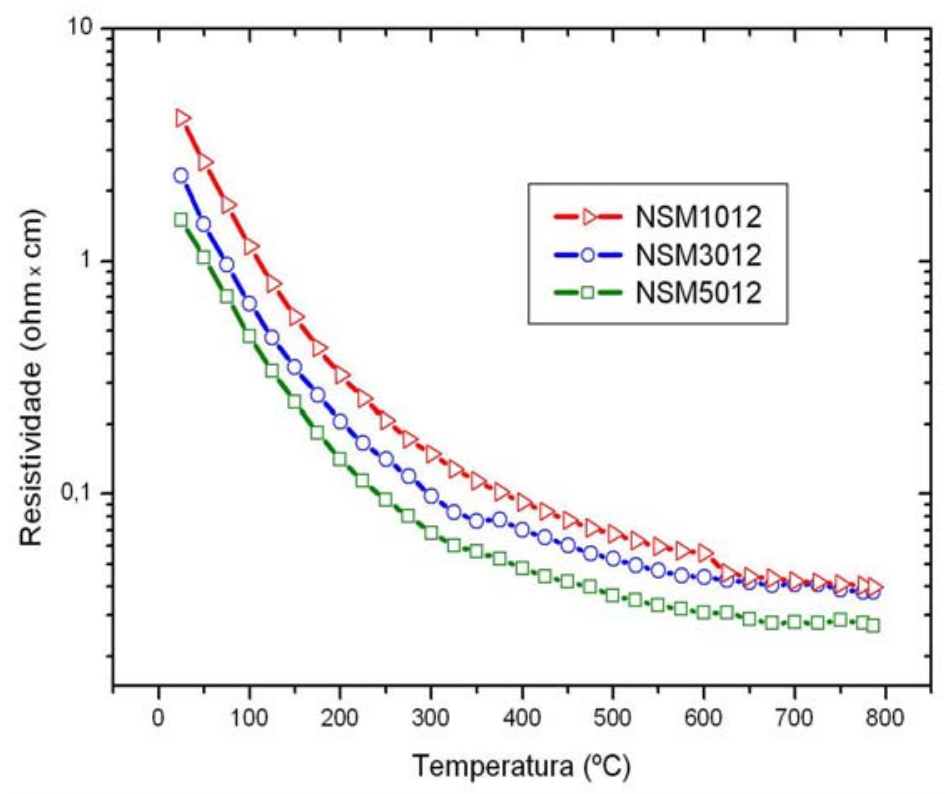

Figura 5.16 - Resistividade elétrica para as amostras de NSM sinterizadas a $1200{ }^{\circ} \mathrm{C}$.

De acordo com a Figura 5.16, a amostra estequiométrica do composto com $50 \%$ em mol de $\mathrm{Sr}$, tem valores de resistividade elétrica inferiores aos compostos com 10 e $30 \%$ em mol de dopante, devido principalmente a diferença estequiométrica no sítio $A$ da estrutura cristalina $\left(\mathrm{ABO}_{3}\right)$, aumentando, conseqüentemente, a sua condutividade elétrica.

Esta diferença é mais pronunciada em baixas temperaturas, mas acima de $500{ }^{\circ} \mathrm{C}$, os valores da condutividade elétrica dos três compostos são relativamente próximos. A introdução de deficiência catiônica no sítio $A$, alterando 
a razão $A / B$ de óxidos do tipo $A B O_{3}$, é um artifício utilizado na pesquisa de materiais para componentes nas SOFCs, pois o estudo de compostos com razão $\mathrm{A} / \mathrm{B}<1$ tem como objetivo diminuir a reatividade das pseudo-perovskitas dopadas com os eletrólitos à base de GDC e $S D C$.

A dependência da condutividade elétrica com a temperatura para todas as amostras pode ser analisada conforme apresentada na Figura 5.17.

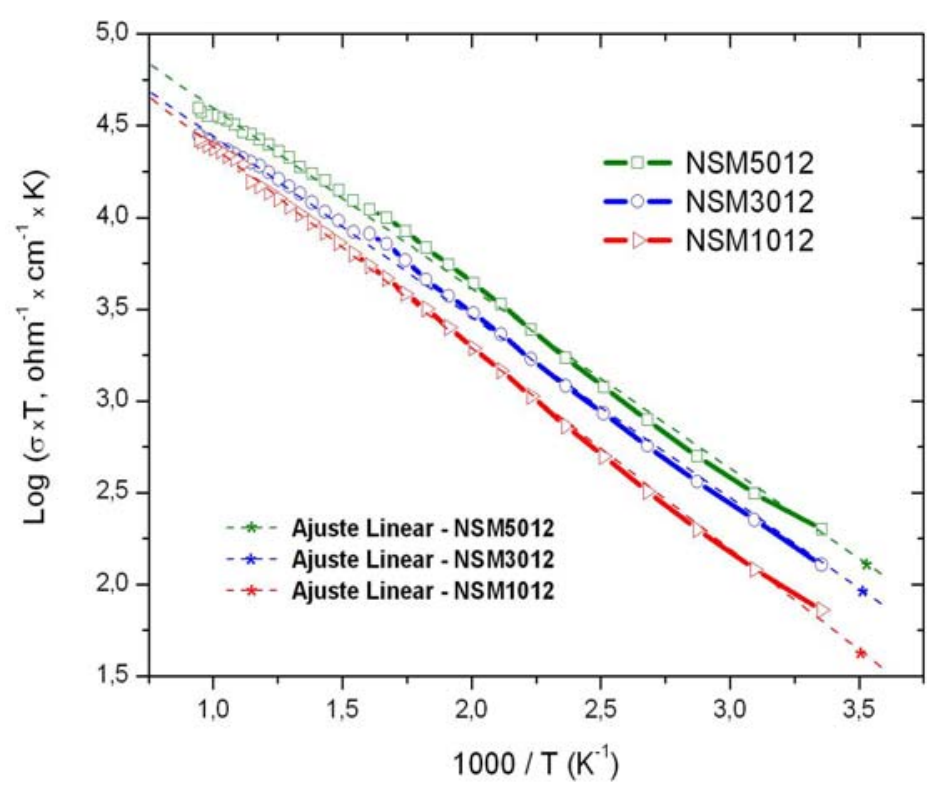

Figura 5.17 - Condutividade elétrica em função da temperatura (curva de Arrhenius) para as amostras de NSM sinterizadas a $1200^{\circ} \mathrm{C}$.

Segundo a literatura ${ }^{(7,8,15,95)}$, estes compostos exibem uma dependência com a pressão parcial do oxigênio, que é característica de semicondutores do tipo $p$, para valores menores que $10^{-5}$ atm até $800{ }^{\circ} \mathrm{C}$ e, na faixa de temperatura investigada, a condutividade elétrica destes óxidos é essencialmente independente da pressão parcial de $\mathrm{O}_{2}{ }^{(98)}$.

A contribuição do eletrodo (nesse caso o catodo) para o valor da condutividade é aproximadamente a mesma em todas as amostras sinterizadas a $1200{ }^{\circ} \mathrm{C}$. As micrografias apresentadas pelo MEV e os resultados das análises de DRX confirmam esta hipótese, pois o arranjo cristalino identificado (pseudoperovskita ortorrômbica) é o mesmo, os contatos entre os grãos nas três amostras são bastante efetivos ${ }^{(98)}$ e, a quantidade de fase secundária de $\mathrm{Nd}_{2} \mathrm{O}_{2}$ está presente em praticamente todas as amostras, em pequenas quantidades e, são relativamente próximas entre si. 
Todas as amostras foram produzidas dentro do mesmo rigor de síntese e processamento de seus respectivos pós precursores, e no tratamento térmico de sinterização. Portanto, a diferença apresentada no comportamento da condutividade pode ser inferida a propriedade intrínseca do material e a principal variável que as diferencia é a composição de seus elementos constituintes, principalmente em relação ao dopante Sr.

Conforme observado a partir da análise de FRX, a amostra NSM1012 apresentou uma menor quantidade de dopante Sr em sua estrutura. Embora não se possa atribuir um valor absoluto a sua condutividade, pode-se concluir que a condutividade da amostra NSM1012 é menor que da amostra NSM3012 e, conseqüentemente, da amostra NSM5012, além de apresentar maior decréscimo da sua condutividade para menores valores de temperatura.

Os valores de condutividade elétrica foram calculados a partir da curva de Arrhenius e são apresentados na Tabela 5.15.

Tabela 5.15 - Condutividade elétrica das amostras de NSM sinterizadas a $1200^{\circ} \mathrm{C}$.

\begin{tabular}{ccc}
\hline \multirow{2}{*}{ Amostras } & \multicolumn{2}{c}{ Condutividade elétrica $\left(\mathbf{S c m}^{-1}\right)$} \\
\cline { 2 - 3 } & $\left(\mathbf{6 5 0}{ }^{\circ} \mathbf{C}\right)$ & $\left(\mathbf{8 0 0}{ }^{\circ} \mathbf{C}\right)$ \\
\hline NSM1012 & 22,7 & 25,2 \\
NSM3012 & 24,0 & 26,4 \\
NSM5012 & 34,6 & 37,1 \\
\hline
\end{tabular}

A partir dos dados de ajuste linear da Figura 5.17, foram calculadas as energias de ativação para todos os compostos de NSM sinterizados a $1200{ }^{\circ} \mathrm{C}$. Os resultados obtidos são apresentados na Tabela 5.16.

Tabela 5.16 - Energia de ativação das amostras de NSM sinterizadas a $1200{ }^{\circ} \mathrm{C}$.

\begin{tabular}{ccc}
\hline \multirow{2}{*}{ Amostras } & \multicolumn{2}{c}{ Energia de Ativação $(\mathbf{e V})$} \\
\cline { 2 - 3 } & $\left(\mathbf{2 5} \mathbf{a ~ 8 0 0}{ }^{\circ} \mathbf{C}\right)$ & $\left(\mathbf{5 0 0} \mathbf{a ~ 8 0 0}{ }^{\circ} \mathbf{C}\right)$ \\
\hline NSM1012 & 0,218 & 0,215 \\
NSM3012 & 0,195 & 0,151 \\
NSM5012 & 0,195 & 0,147 \\
\hline
\end{tabular}

Os valores de energia de ativação apresentados na tabela acima estão coerentes com os valores de compostos similares encontrados na literatura (95) para esta mesma faixa de temperatura.

Entretanto, os valores de condutividade elétrica do composto com $50 \%$ em mol de Sr é consideravelmente maior do que os compostos com 10 e $30 \%$ 
em mol de dopante ${ }^{(95)}$. Este fato é esperado, pois a introdução de íons, através da formação de pares $\mathrm{Mn}^{3+} / \mathrm{Mn}^{4+}$, é promovida pela substituição de $\mathrm{Nd}^{3+}$ por $\mathrm{Sr}^{2+}$, aumentando assim a condutividade elétrica ${ }^{(99)}$.

Os resultados indicaram que, a $650^{\circ} \mathrm{C}$, a amostra NSM1012 apresenta valor de energia de ativação $E=0,215 \mathrm{eV}$ e condutividade elétrica 22,7 Scm $\mathrm{Sc}^{-1}$, a amostra NSM3012 apresenta $E=0,151 \mathrm{eV}$ e condutividade 24,0 Scm ${ }^{-1}$ e, para a amostra NSM5012, E = 0,147 eV e condutividade 34,6 Scm${ }^{-1}$.

De acordo com os resultados obtidos e comprovando com a literatura $(7,8,15,95)$, à medida que se aumenta o teor do dopante estrôncio, a condutividade elétrica aumenta e a energia de ativação diminui.

A literatura indica que a faixa de condutividade ideal para um catodo de NSM operando a aproximadamente $800{ }^{\circ} \mathrm{C}$ é de 40 a $140 \mathrm{Scm}^{-1}{ }^{(95)}$. Entretanto, em diversas publicações são encontrados valores entre 5 e 200 Scm $^{-1}(7,8,15,95)$ para operações entre 650 e $1000^{\circ} \mathrm{C}$. 


\section{CONCLUSÕES}

A técnica de mistura de sólidos possibilitou a síntese dos pós de manganito de neodímio dopado com estrôncio.

Os resultados obtidos por ATG e ATD mostram uma perda de massa referente aos precursores na forma de carbonatos durante a formação do óxido estável de $\mathrm{NdSrMnO}_{3}$.

Foi possível a remoção de mais de $97 \%$ do teor de carbono após a realização do tratamento térmico a $1100^{\circ} \mathrm{C}$ por 4 horas para todas as amostras.

As análises por FRX-EDS mostraram que a síntese obteve as composições de NSM10, NSM30 e NSM50 (10, 30 e 50 \% em mol de Sr), com valores aproximados aos calculados estequiometricamente, apesar da pequena perda de estequiometria, que é característica da própria rota de síntese.

O diâmetro médio equivalente dos pós de NSM ficou aproximadamente entre 0,26 e 0,30 $\mu \mathrm{m}$ através do zetâmetro e de 0,35 $\mu \mathrm{m}$ pela distribuição granulométrica, sendo adequados para a preparação de suspensões cerâmicas.

A área de superfície específica das partículas diminui relativamente pouco com o aumento do teor de estrôncio. O resultado é confirmado com a uniformidade dos valores de diâmetro médio dos pós, que está entre 0,09 e 0,12 $\mu \mathrm{m}$. Este resultado mostra realmente que as partículas são aproximadamente nanométricas e adequadas para a preparação de suspensões cerâmicas.

Os valores das densidades reais estão muito próximos das densidades teóricas. Para os três materiais na forma de pós, as densidades reais correspondem a mais de $91 \%$ da densidade teórica.

As micrografias dos pós obtidas por MEV, mostram que os tamanhos das partículas são inferiores a $0,5 \mu \mathrm{m}$ e a forma dos aglomerados são relativamente semelhantes e homogêneas para os três materiais.

As amostras em forma de pós foram observadas por DRX, obtendo-se a formação da principal fase NSM e uma pequena quantidade de fase secundária de $\mathrm{Nd}_{2} \mathrm{O}_{3}$, decorrentes da não reação completa de alguns cátions $\mathrm{Nd}^{3+}$ na cadeia principal, para a formação dos compostos em estudo. A estrutura cristalina encontrada para os três materiais é pseudo-perovskita ortorrômbica. 
O estudo da dilatometria, realizado com as amostras a verde, verificou que temperaturas entre 1100 e $1400^{\circ} \mathrm{C}$ são as mais adequadas para a realização do estudo de sinterização.

As amostras sinterizadas a 1100 e $1200^{\circ} \mathrm{C}$ obteve maior porosidade em relação às amostras sinterizadas a 1300 e $1400{ }^{\circ} \mathrm{C}$, pois estas últimas apresentaram uma maior densificação.

Os resultados de porosidades, para as amostras sinterizadas a $1100^{\circ} \mathrm{C}$ variam entre 20 e $35 \%$, para as amostras sinterizadas a $1200{ }^{\circ} \mathrm{C}$ variam entre 19 e $30 \%$, para as amostras a $1300{ }^{\circ} \mathrm{C}$, entre 18 e $26 \%$ e finalmente para as amostras a $1400^{\circ} \mathrm{C}$ entre 14 e $25 \%$. Estes resultados comprovam aparentemente os dados observados nas micrografias das superfícies fraturadas. As porosidades das amostras sinterizadas a 1100 e $1200^{\circ} \mathrm{C}$ são adequadas para o fluxo de gás oxidante no catodo da ITSOFC.

As superfícies fraturadas tratadas termicamente permitem observar que no geral, os tamanhos médios de grãos aumentam relativamente com a temperatura de sinterização e com o aumento do teor de Sr.

As amostras sinterizadas analisadas por DRX mostraram a presença da estrutura pseudo-perovskita ortorrômbica, indicando que a estrutura cristalina desses materiais nas temperaturas de 1100 e $1200{ }^{\circ} \mathrm{C}$, não ocorrem grandes transformações estruturais entre os pós e as cerâmicas processadas. Nas temperaturas de $1300{ }^{\circ} \mathrm{C}$ aparece pequena quantidade de $\mathrm{Nd}_{2} \mathrm{O}_{3}$ e a $1400{ }^{\circ} \mathrm{C}$ a formação dessa fase sencundária fica mais intensa.

Os valores do coeficiente de expansão térmica se mostram muito bons para todas as amostras, com valores dentro da faixa de operação dos eletrólitos sólidos comerciais de GDC $\left(13,4 \times 10^{-6}{ }^{\circ} \mathrm{C}^{-1}\right)$ e $S D C 12,7 \times 10^{-6}{ }^{\circ} \mathrm{C}^{-1}{ }^{(97)}$.

A composição NSM3012 apresentou os melhores resultados, com valores de porosidade razoáveis e próximos a $25 \%$, coeficiente de expansão térmica a $13,31 \times 10^{-6}{ }^{\circ} \mathrm{C}^{-1}$ e condutividade elétrica de $24 \mathrm{Scm}^{-1}$.

Conclui-se que as características do material com composição de $30 \%$ em mol de Sr é a mais adequada para a preparação de suspensões cerâmicas para posterior deposição no eletrólito sólido de GDC e/ou $S D C$, embora sejam necessários outros estudos para otimização das características deste material como dispositivo eletroquímico para aplicação em ITSOFCs. 


\section{SUGESTÕES PARA TRABALHOS FUTUROS}

A partir dos resultados obtidos neste trabalho, são sugeridos:

- Estudar o processamento cerâmico e caracterização das amostras NSM30 e NSM50 com substâncias formadoras de porosidade e comparar com os resultados obtidos no presente trabalho;

- Estudar o controle de porosidade em função da permeabilidade do gás oxigênio $\left(\mathrm{O}_{2}\right)$;

- Estudar as propriedades mecânicas destas amostras para aplicações como catodo e para o empilhamento das células unitárias;

- Estudar e analisar as características elétricas para as amostras em diferentes condições de sinterização.

- Caracterizar eletricamente as amostras sinterizadas obtidas neste trabalho para melhor entendimento das medidas de condutividade elétrica e das etapas limitantes nas reações catódicas das ITSOFCs;

- Estudar a influência do pH para a preparação de suspensões de NSM;

- Estudar e otimizar as condições reológicas das suspensões e a concentração dos diversos aditivos visando o estabelecimento de uma rota de processamento em um substrato de eletrólito para a ITSOFC. 


\section{PUBLICAÇÕES}

\section{Artigos completos publicados em periódicos:}

1. VARGAS, R. A; CHIBA, R; ANDREOLI, M; SEO, E. S. M. Síntese e Caracterização dos Pós de Nd1-xSrxMnO3 e La1-xSrxCo1-yFeyO3. Revista Matéria (UFRJ), v. 12, p. 8-21, 2007.

2. CHIBA, R; VARGAS, R. A; ANDREOLI, M; SEO, E. S. M. Strontium-doped lanthanum manganite powders used as cathode in solid oxide fuel cells. Revista Ciências Exatas, v. 11, p. 63-73, 2007.

3. CHIBA, R; VARGAS, R. A; ANDREOLI, M; SEO, E. S. M. Solid oxide fuel cells: strontium-doped lanthanum manganite obtained by the citrate techinique. Materials Science Forum, v. 530-31, p. 643-648, 2006.

\section{Artigos aguardando publicação:}

1. VARGAS, R. A; CHIBA, R; ANDREOLI, M; SEO, E. S. M. Synthesis and characterization of La1-XSrXMnO3 and La1-XSrXCo1-YFeYO3 used as cathode in solid oxide fuel cell. Materials Research, 2007.

2. CHIBA, R; VARGAS, R. A; ANDREOLI, M; SEO, E. S. M. Influence of the strontium dopant concentrations in the synthesis of lanthanum manganite. Materials Research, 2007.

3. CHIBA, R; VARGAS, R. A; ANDREOLI, M; SEO, E. S. M. Catodo para Célula a Combustível de Óxido Sólido: Síntese e Caracterização de Manganito de Lantânio Dopado com Estrôncio. Matéria (UFRJ), 2006. 


\section{Capítulo de livro publicado:}

1. VARGAS, R. A ; CHIBA, R ; SEO, E. S. M . A CÉLULA A ÓXIDO SÓLIDO (SOFC). In: FRANCO, E.G. (Org.). CÉlULAS A COMBUSTíVEL. 1 ed. Lavras, MG, Brasil: Universidade Federal de Lavras, Fundação de Apoio ao ensino, Pesquisa e Extensão, 2005, v. 01, p. 71-89.

\section{Trabalhos completos publicados em anais de congressos:}

1. RODRIGUES, R. A; CHIBA, R; VARGAS, R. A; ANDREOLI, M; SEO, E. S. M; LAZAR, D. R. R; YOSHITO, W. K; LIMA, N. B; USSUI, V. Características dos pós da mistura de manganito de lantânio dopado com estrôncio e zircônia estabilizada com ítria na formação do compósito LSM-YSZ. In: 51ํ Congresso Brasileiro de Cerâmica, 2007, Salvador, BA. Anais do $51^{\circ}$ Congresso Brasileiro de Cerâmica. São Paulo, SP : Assoçiação Brasileira de Cerâmica (ABC), 2007.

2. VARGAS, R. A; CHIBA, R; FRANCO, E. G; SEO, E. S. M. Uma visão da tecnologia de células a combustível. In: $1^{\circ}$ Congresso de Administração da Faculdade Alfacastelo $\left(1^{\circ}\right.$ CONALFA), 2006, Barueri, SP. $1^{\circ}$ Congresso de Administração da Faculdade Alfacastelo. Barueri, SP : Alfacastelo, 2006. p. 1-13.

3. VARGAS, R. A; CHIBA, R; FRANCO, E. G; SEO, E. S. M. Hidrogênio: O vetor energético do futuro?. In: $1^{\circ}$ Congresso de Administração da Faculdade Alfacastelo (1º CONALFA), 2006, Barueri, São Paulo. $1^{\circ}$ Congresso de Administração da Faculdade Alfacastelo. Barueri, São Paulo. Faculdade Alcastelo, 2006. p. 1-13.

4. CHIBA, R; VARGAS, R. A; ANDREOLI, M; SEO, E. S. M. Influência das concentrações do dopante estrôncio na síntese de manganito de lantânio. In: 17 Congresso Brasileiro de Engenharia e Ciência dos Materiais ( $17^{\circ}$ CBECIMAT), 2006, Foz do Iguaçu, PR. Anais do 17 Congresso Brasileiro de Engenharia e Ciência dos Materiais (CBECIMAT). São Paulo, SP : CBECiMat, 2006.

5. VARGAS, R. A; CHIBA, R; ANDREOLI, M; SEO, E. S. M. Síntese e caracterização de La1-XSrXMnO3 e La1-XSrXCo1-YFeYO3 utilizados como catodo em células a combustível de óxido sólido. In: $17^{\circ}$ Congresso Brasileiro de Ciência e Engenharia de Materiais (17 $7^{\circ}$ CBECiMat), 2006, Foz do Iguaçu, PR. $17^{\circ}$ Congresso Brasileiro de Ciência e Engenharia de Materiais. São Paulo, SP: CBECiMat, 2006. 
6. CHIBA, R; VARGAS, R. A; ANDREOLI, M; SEO, E. S. M. Strontium-doped lanthanum manganite powders used as cathode in solid oxide fuel cells. In: $1^{\circ}$ Jornadas IberoAmericanas de Células a Combustível e Hidrogênio (JIPCH), 2005, Ubatuba, São Paulo, Brasil. $1^{\circ}$ Jornadas Ibero-Americanas de Células a Combustível e Hidrogênio. São Paulo, São Paulo, Brasil : Universidade Estadual Paulista (UNESP), 2005.

7. CHIBA, R ; VARGAS, R. A ; ANDREOLI, M ; SEO, E. S. M. Solid oxide fuel cells: strontium-doped lanthanum manganite obtained by the citrate technique. In: Fifth International Latin-American Conference on Powder Technology, 2005, Salvador, BA. Fifth International Latin-American Conference on Powder Technology. São Paulo, SP : PTECH, 2005.

8. VARGAS, R. A; ANDREOLI, M; LIMA, N. B; SEO, E. S. M. Preparação e caracterização de $\mathrm{Nd} 1-\mathrm{XS} X \mathrm{MnO} 3$ como material catódico de células a combustível do tipo ITSOFC. In: 49 Congresso Brasileiro de Cerâmica (49 CBC), 2005, São Pedro, SP. Anais do 49 Congresso Brasileiro de Cerâmica. São Paulo, SP : Associação Brasileira de Cerâmica (ABC), 2005.

\section{Demais tipos de produção bibliográfica:}

1. VARGAS, R. A. Ampliação de escala das células a combustível do laboratório para a escala industrial e fatores importantes a serem destacados. São Paulo: Instituto de Pesquisas Energéticas e Nucleares (IPEN), 2005 (Monografia de Conclusão de Disciplina de Pós-Graduação).

2. VARGAS, R. A. Célula a combustível de óxido sólido de temperatura intermediária e seus principais componentes. São Paulo: Instituto de Pesquisas Energéticas e Nucleares (IPEN), 2005 (Monografia de Conclusão de Disciplina de Pós-Graduação).

3. VARGAS, R. A. Célula a combustível de óxido sólido e influência da temperatura de operação. São Paulo: Instituto de Pesquisas Energéticas e Nucleares (IPEN), 2005 (Monografia de Conclusão de Disciplina de Pós-Graduação). 


\section{REFERÊNCIAS BIBLIOGRÁFICAS}

(1) HINRICHS, R.A. KLEINBACH, M. Energia e Meio Ambiente. 1 ed. Thomson Learning, 2003.

(2) BRANCO, A.M. Política Energética e Crise de Desenvolvimento. 1 ed. Paz e Terra, 2002.

(3) REIS, L.B., SILVEIRA, S. Energia Elétrica para o Desenvolvimento Sustentável. 1ed. Edusp, 2000.

(4) ALBADÓ, R. Célula Combustível a Hidrogênio: Fonte de Energia da Nova Era. São Paulo, S.P.: Artiliber Editora Ltda, 2004.

(5) EG\&G Technical Services; Parsons Inc. Fuel Cell Handbook Seventh Edition. Morgantown, W.Va. U.S: Department of Energy, 2004.

(6) YAMAMOTO, O. Solid Oxide Fuel Cells: fundamental Aspects and Prospects. Electrochimica. Acta, v. 15, n. 15-16, p. 2423-2435, 2000.

(7) SAKAKI, Y.; TAKEDA, Y.; KATO, A.; IMANISHI, N.; YAMAMOTO, O.;

HATTORI, M.; LIO, M.; ESAKI, Y. Ln1-xSrxMnO3 (Ln = Pr, Nd, Sm and Gd) as the cathode material for solid oxide fuel cells. Solid State lonics, n. 118, p. 187194, 1999.

(8) WEN, T.L.; TU, H.; XU, Z.; YAMAMOTO, O. A study of (Pr, Nd, Sm)1xSrxMnO3 cathode materials for solid oxide fuel cell. Solid State lonics, n. 121, p. 25-30, 1999.

(9) MINH, N.Q. Ceramic fuel cells. Journal of the American Ceramic Society, v. 76, n. 3, p. 563-588, Mar. 1993.

(10) MINH, N.Q. Solid oxide fuel cell technology - features and applications. Solid State lonics, v. 174, n. 1-4, p. 271-277, Oct. 2004.

(11) ZHANG, Q.; NAKAGAWA, T.; SAITO, F. Mechanochemical synthesis of $\mathrm{La}_{0,7} \mathrm{Sr}_{0,3} \mathrm{MnO}_{3}$ by grinding constituent oxides. Jornal of. Alloys and Compounds., v. 308, p.121-125, 2000.

(12) CHOY, K.L.; CHAROJROCHKUL, S.; STEELE, B.C.H. Fabrication of cathode for solid oxide fuel cells using flame assisted vapour deposition technique.

Solid State Ionics, v. 96, p. 49-54, 1997.

(13) ARUNA, S.T.; MUTHURAMAN, M.; KASHINARH, P.C. Combustion synthesis and properties of strontium substituted lanthanum manganites $\mathrm{La}_{1-\mathrm{x}} \mathrm{Sr}_{\mathrm{x}} \mathrm{MnO}_{3}(0$ $\leq \mathrm{x} \leq 0,3$ ). Journal of Materials Chemistry, v. 7, n. 12, p. 2499-2503, 1997. 
(14) MINISTÉRIO DA CIÊNCIA E TECNOLOGIA. Fundo Setorial de Energia. Secretaria Técnica. Programa Brasileiro de Células a Combustível: proposta para o programa. Brasília, DF: Centro de Gestão e Estudos Estratégicos CGEE, 2002.

(15) KOSTOGLOUDIS, G.CH.; VASILAKOS, N.; FTIKOS, J.; Preparation and characterization of $\operatorname{Pr}_{1-x} \mathrm{Sr}_{x} \mathrm{MnO}_{3 \pm \delta}(x=0,0.15,0.3,0.4,0.5)$ as a potential SOFC cathode material operating at intermediate temperatures $\left(500-700^{\circ} \mathrm{C}\right)$. Journal of European Ceramic Society, v. 17, n. 12, p. 1513-1521, Feb. 1997.

(16) BLOMEN, J.M.J.; MUGERWA, M.N. Fuel Cell Systems. New York: Plenum Press, 1993.

(17) KORDESCH, K.; SIMADER, G. Fuel Cells and Their Applications. Weinheim, New York, Basel, Cambridge, Tokyo: VCH, 1996.

(18) NASA. National Aeronautics And Space Administration. Disponível em: <http://www.nasa.gov>. Acesso em: 10 abr. 2007.

(19) RISO ENERGY REPORT. New and emerging technologies - options for the future. Riso National Laboratory. October, 2002.

(20) NETO, E. H. G. Hidrogênio: Evoluir sem poluir, 1 ed., Brasil H2 Fuel Cell Energy, 2005.

(21) Portal H2. Células a Combustível e Hidrogênio. Disponível em: <http://www.brasilh2.com.br>. Acesso em: 10 abr. 2007.

(22) LINDEN, D. Handbook of Batteries and Fuel Cells. New York, N.Y.: McGrawHill Book Company, 1984.

(23) WENDT, H.; LINARDI, M.; ARICÓ, E.M. Células a Combustível de Baixa Potência para Aplicações Estacionárias. Química nova, v. 25, n. 3, p. 470-476, 2002.

(24) CHIBA, R. Obtenção e Caracterização de Manganito de Lantânio Dopado com Estrôncio para Aplicação em Células a Combustível de Óxido Sólido. Dissertação M.Sc. em Tecnologia Nuclear - Materiais, Instituto de Pesquisas Energéticas e Nucleares, IPEN/CNEN-SP, São Paulo, Maio 2005.

(25) SINGHAL, S.C.; KENDALL, K. High-temperature Solid Oxide Fuel Cells: Fundamentals, Design and Applications. 1 ed., Elsevier, 2004.

(26) CHOY, K.; BAI, W.; CHAROJROCHKUL, S.; STEELE, B.C.H. The development of intermediate-temperature solid oxide fuel cells for the next millennium. Journal of Power Sources, v. 71, n. 1-2, p. 361-369, Mar. 1998.

(27) WENDT, H.; GÖTZ, M.; LINARDI, M. Tecnologia de Células a Combustível. Química Nova, v. 23, n. 4, p. 538-546, 2000. 
(28) SEO, E.S.M.; YOSHITO, W.K.; USSUI, V.; LAZAR, D.R.R.; MELLO CASTANHO, S. R.H.; PASCHOAL, J.O.A. Influence of the starting materials on performance of high temperature oxide fuel cells devices. Materials Research, v. 7, p. 215-220, 2004.

(29) SETZ, L.F.G. Obtenção de $\mathrm{La}_{1-x} \mathrm{Sr}_{x} \mathrm{Cr}_{1-y} \mathrm{Co}_{y} \mathrm{O}_{3}$ por Reação de Combustão. Dissertação M.Sc. em Tecnologia Nuclear - Materiais, Instituto de Pesquisas Energéticas e Nucleares, IPEN/CNEN-SP, São Paulo, 2005.

(30) U.S. Department of Energy. Departamento de Energia dos EUA. Disponível em: <http://www.energy.gov/>. Acesso em: 15 abr. 2007.

(31) BCC. Business Communications Company. Disponível em: $<$ http://www.bccresearch.com/bio/ >. Acesso em: 15 abr. 2007.

(32) FULLER, T.F. Is a Fuel Cell in Your Future?. Journal of the Electrochemical Society, v. 6, n. 3, p. 26-32, 1997.

(33) JOON, K. Fuel Cells-a $21^{\text {st }}$ century power system. Journal of Power Sources, v. 71, p.12-18, 1998.

(34) FUEL CELL TECHNOLOGY REVIEW CONFERENCE - High Temperature Fuel Cell Component Research, August 3-5, 1999, Chicago, Illinois - U.S. Proceedings. Chicago, 1999, ref. fc7-2.

(35) SINGHAL, S.C. Advances in solid oxide fuel cell technology. Solid State lonics, v. 135, n. 1-4, p. 305-313, Nov. 2000.

(36) CACCIOLA, G.; ANTONUCCI, V.; FRENI, S. Technology up date and new strategies on fuel cells. Journal of Power Sources, v. 100, p. 67 - 79, 2001.

(37) SECA. Solid State Energy Conversion Alliance. Disponível em: $<$ <ttp://www.netl.doe.gov/technologies/coalpower/fuelcells/seca/>. Acesso em: 8 mai. 2007.

(38) RISE. Research Institute Sustainable Energy. Disponível em: <http://www.rise.org.au/info/Tech/fuelcells/index.html>. Acesso em: 8 mai. 2007.

(39) GEIGER, S. Fuel Cells in Brazil - A Survey of Current Developments. Fuel Cell Today, 26 mar 2003.

(40) MCT. Ministério da Ciência e Tecnologia. Disponível em: <http://www.mct.gov.br/>. Acesso em: 12 mai. 2007.

(41) LI, X. Principles of fuel cell. New York, N.Y.: Taylon \& Francis, 2006.

(42) VARGAS, R. A; CHIBA, R; ANDREOLI, M; SEO, E. S. M. Síntese e Caracterização dos Pós de Nd1-xSrxMnO3 e La1-xSrxCo1-yFeyO3. Revista Matéria (UFRJ), v. 12, p. 8-21, 2007. 
(43) BADWAL, S.P.S. Stability of Solid Oxide Fuel Cell Compoments. Solid State lonics, v. 143, p. 39 - 46, 2001.

(44) AMADO, R.S.; MALTA, L.F.B.; GARRIDO, F.M.S.; MEDEIROS, M.E. Pilha a Combustível de Óxido Sólido: Materiais, Componentes e Configurações, Química Nova, v. 30, n. 1, p. 189-197, 2007.

(45) TIFFEÉ, E.I.; WEBER, A.; HERBSTRITT, D. Materials and Technologies for SOFC - components. Journal of the European Ceramic Society, v. 21, p. 1806, 2001.

(46) BADWAL, S.P.S.; FOGER, K. Materials for solid oxide fuel cells. Materials Science Forum, v. 21, p. 187-224, 1997.

(47) MIZUTANI, Y.M.; TAMURA, M. K.; YAMAMOTO, O. Development of highperformance electrolyte in SOFC. Solid State lonics, v. 72, p. 271-275, 1994.

(48) FERGUS, J.W. Sealants for solid oxide fuel cells. Journal of Power Sources, v. 147, n. 1-2, p. 46-57, 2005.

(49) TAKEDA, Y.; SAKAKI, Y.; ICHIKAWA, T.; IMANISHI, N.; YAMAMOTO, O.; MORI, M.; MORI, N.; ABE, T. Stability of $\mathrm{La}_{1-x} \mathrm{~A}_{x} \mathrm{MnO}_{3-z}(\mathrm{~A}=\mathrm{Ca}, \mathrm{Sr})$ as cathode materials for solid oxide fuel cells., Solid State Ionics, v. 72, p. 257-264, 1994.

(50) SCHÄFER, W.; KOCH, A.; HEROLD-SCHIMIDT, U.; STOLTEN, D. Materials and interfaces and production techniques for planar solid oxide fuel cell. Solid State lonics, v. 86-88, p. 1235-1239, 1996.

(51) SINGHAL, S.C. Advances in tubular solid oxide fuel cell technology. Fuel Cell Seminar, Orlando, p. 28, 1996.

(52) HAYNES, C.; WEPPER, W.J. Design for power of a commercial grade tubular solid oxid fuel cell. Energy Conversion \& Management, v. 41, p. 1123-1139, 2000.

(53) MAJUMDAR, S.; CLAAR, T.; FLANDERMEYER, B. Stress and fracture behavior of monolithic fuel cell types. Journal of American Ceramic Society, v. 69, p. $628-633,1986$.

(54) Siemens Westinghouse. Power Generation. Disponível em: $<$ http://www.powergeneration.siemens.com/en/index.cfm >. Acesso em: 15 mai. 2007.

(55) ZHU, B. Advantages of intermediate temperature solid oxide fuel cells for stationary applications. Journal of Power Sources, v. 93, p. 82-86, 2001.

(56) Rede PaCOS. Rede Cooperativa Pilha a Combustível de Óxido Sólido. Disponível em: <http://www.redepacos.coppe.ufrj.br/index.php?hl=0>. Acesso em: 8 abr. 2007. 
(57) EGUCHI, K. Ceramic materials containing rare earth oxides for solid fuel cell. Journal of Alloys Compounds, v. 250, p. 486-491, 1997.

(58) CALLISTER JR, W.D. Materials Science and Engineering: An Introduction. 4 ed. New York, N.Y.: Wiley, 1997.

(59) VAN VLACK, L.H. Princípios de Ciência dos Materiais. 7 ed., São Paulo, S.P.: Editora Edgard Blücher Ltda, 1985.

(60) TEJUCA, L.G. Properties and applications of perovskite-type oxides, 1 ed., New York: Dekker, 1993.

(61) MATÍNEZ, J.P.; LÓPEZ, D.M.; MORALES, J.C.R.; BUERGLER, B.E.; NÚÑEZ, P.; GAUCKLER, L.J.; Fuel cell studies of perovskite-type materials for IT-SOFC. Journal of Power Sources, v. 159, p. 914-921, 2006.

(62) LÓPEZ, P.E.; CASTELLÓ, J.B.; CORDONCILLO, E.C. Esmaltes y Pigmentos Cerámicos, Castellón: Faeza Edictre Ibérica, 2001.

(63) KAKIHANA, M.; YOSHIMURA, M. Synthesis an Characteristics of Complex Multicomponent Oxides Prepared by Polymer Complex Method. Bulletin Chemical Society of Japan, v. 72, p. 1427-1443, 1999.

(64) GOUVEIA, D. S. Espinélios Zn7-xCoxSb2O12 (x = 0-7) Obtidos pelo Método Pechini. Dissertação M.Sc. em Química, Universidade Federal da Paraíba, João Pessoa, PB, 2002.

(65) GERMAN, R. M. Powder Metallurgy Science, Metal Powder Industries Federation, Princeton, New Jersey, 1984.

(66) GERMAN, R. M. Sintering Theory and Practice. 1.ed. John Wiley \& Sons, 1996.

(67) CHIANG, Y.M.; BIRNIE, D ; KINGERY,W.D. Physical Ceramics - Principles for Ceramic Science and Engineering. The MIT Series in Material Science and Engineering. 1.ed. John Wiley \& Sons, 1997.

(68) RICHERSON, D. Modern Ceramic Engineering, properties, processing and use in design. 2.ed. Marcel Dekker, 1992.

(69) WELLER, M.T. Inorganic Materials Chemistry. v. 23, New York, N.Y.: Oxford University Press, Inc., 1994.

(70) POTTER, M. C.; SCOTT, E. P. Ciências Térmicas. 1 ed. Thomson Learning Edições Ltda, 2006.

(71) TIPLER, P. A.; MOSCA, G. Física Para Cientistas e Engenheiros Vol. 2 Eletricidade, Magnetismo e Ótica. 1 ed. LTC, 2006. 
(72) MACDONALD, J.R. Impedance Spectroscopy - Emphasizing Solid Materials and Systems. New York. N.Y: John Wiley \& Sons, 1987.

(73) ACCHAR, W. Materiais Cerâmicos - Caracterização e aplicações. Natal. RN.: UFRN, 2006.

(74) WEST, A.R. Solid State Chemistry and its Applications. New York: John Wiley \& Sons, 1984.

(75) LECO CS400. Carbon and Sulfur Determination. Disponível em: <http://www.leco.com>. Acesso em: 10 mar. 2007.

(76) EWING, G,W. Métodos Instrumentais de Análise Química. São Paulo: Edgard Blucher, v.1, 1972.

(77) SHIMADZU. Espectrômetro de Fluorescência de raios X por Energia Dispersiva. Disponível em: <http://www.shimadzu.com.br>. Acesso em: 20 mar. 2007.

(78) Instruction Manual Multivolume. Pycnometer Micromeritics 1305. 1987.

(79) REED, J.S. Principles of Ceramics Processing. New York: John Wiley \& Sons, 2 ed, 1995.

(80) ONODA, J.G.Y.; HENCH, L.L. Ceramic Processing Before Firing. New York: John Wiley \& Sons, 1978.

(81) ALLEN, T. Particle Size Measurement. London: Chapman \& Hall, 1968.

(82) BROOKHAVEN INSTRUMENTS CORPORATION. Instruction Manual for ZetaPlus - Zeta Potencial Analyser, Sept. 1997.

(83) BRUNAUER, S.; EMMETT, P.H.; TELLER, E. Adsorption of gases in multimolecular layers. Journal of American Chemistry Society, v. 60, p. 309319, 1938.

(84) WEBB, P.A.; ORR, C. Analytical Methods in Fine Particle Technology. USA: Micromeritics Instrument corporation, 1997.

(85) ALLEN, T. Surface Area and Pore Size Determination, Particle Size Measurement. London: Chapman \& Hall, v. 2, 1997.

(86) RICCI, D.R.; AMBRÓZIO FILHO, F. Caracterização de pós utilizando-se métodos de determinação de tamanho médio de partículas. Cerâmica, v. 30, n. 180, p. 337-346, 1984.

(87) CULLITY, B.D. Elements of X-Ray Diffraction. Massachusetts: AddisonWesley Publishing Company, 2 ed., 1978. 
(88) GOLDSTEIN, J.I. Scanning Electron Microscopy and X-Ray Microanalysis. New York: Plenum Press, e. 2, 1992.

(89) KESTENBACH, H.J. Microscopia eletrônica: Transmissão e Varredura. Trd. BOTTA FILHO, W. J. São Paulo: Associação Brasileira de Metais, 1989.

(90) FERGUS, J.W. Eletrolytes for solid oxide fuel cells. Journal of Power Sources, v. 162, n. 1, p. $30-40,2006$.

(91) KATAYAMA, K.; ISHIHARA, T.; OHTA, H.; TAKEUCHI, S.; ESAKI, Y.; INUKAI, E. Sintering and electrical conductivity of $\mathrm{La}_{1-\mathrm{x}} \mathrm{Sr}_{\mathrm{x}} \mathrm{MnO}_{3}$. Journal of Ceramic Society, v. 11, p. 1327, 1989.

(92) HAMMOUCHE, A.; SIEBERT, E.; HAMMOU, A. Crystallographic, thermal and electrochemical properties of the system $\mathrm{La}_{1-\mathrm{x}} \mathrm{Sr}_{\mathrm{x}} \mathrm{MnO}_{3}$ for high temperature solid electrolyte fuel cells. Materilas Research. Bulletin, v. 24, p. 367-380, 1989.

(93) JIANG, S.P. A comparison of $\mathrm{O}_{2}$ reduction reactions on porous ( $\left.\mathrm{La}, \mathrm{Sr}\right) \mathrm{MnO}_{3}$ and $(\mathrm{La}, \mathrm{Sr})(\mathrm{Co}, \mathrm{Fe}) \mathrm{MnO}_{3}$ electrodes. Solid State lonics, v. 146, p. 1-22, 2002.

(94) DE HAART, L.G.J.; DE VRIES, K.J. Evaluation of porous ceramic cathode layers for solid oxide fuel cells. Materials Research. Bulletin, v. 26, p. 507-517, 1991.

(95) ARUNA, S. T.; MUTHURAMAN, M.; PATIL, K. C. Studies on substituted rare earth manganites. Solid State lonics, V.120, p. 275-280, 1999.

(96) DYCK, C. R.; YU, Z. B.; KRSTIC, V. D. Thermal expansion matching of Gd1$x$ SrxCoO3- $\delta$ composite cathodes to Ce0.8Gd0.2)1.95 IT-SOFC electrolytes. Solid State lonics, V.171, p. 17-23, 2004.

(97) FUEL CELL MATERIALS. Performance and Quality Delivered: Ceria-Based Electrolytes. Disponível em: <http://www. fuelcellmaterials.com >. Acesso em: 25 abr. 2007.

(98) TAO, S.; IRVINE, J.T.S. Synthesis and Characterization of $\left(\mathrm{La}_{0.75} \mathrm{Sr}_{0.25}\right) \mathrm{Cr}_{0.5} \mathrm{Mn}_{0.5} \mathrm{O}_{3-\mathrm{d}}$, a Redox-stable, Efficient Perovskite Anode for SOFCs, Journal of The Electrochemical Society, v. 151, n. 2, p. A252-A259, 2004.

(99) COEY, J.M.D.; VIRET, M.; VON MOLNÁR, S. Mixed-valence Manganites, Advances in Physics, v. 48, n. 2, p. 167-293, 1999. 
